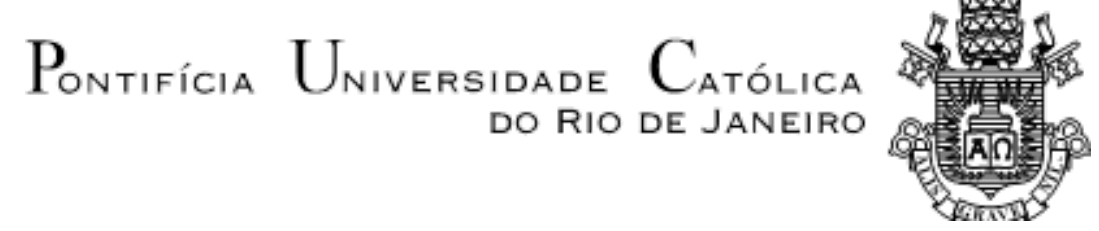

Patricia Siqueira Oliveira A relevância da afetividade nos processos de
aprendizagem

\author{
Dissertação de Mestrado
}

Dissertação apresentada ao Programa de PósGraduação em Psicologia da PUC-Rio como requisito parcial para obtenção do grau de Mestre em Psicologia Clínica.

Orientadora: Profa. Luciana Fontes Pessôa

Rio de Janeiro

Fevereiro de 2018 
Patricia Siqueira Oliveira

\section{A relevância da afetividade nos processos de aprendizagem}

Dissertação apresentada como requisito parcial para obtenção do grau de Mestre pelo Programa de PósGraduação em Psicologia (Psicologia Clínica) da PUCRio. Aprovada pela Comissão Examinadora abaixo assinada.

Profa. Luciana Fontes Pessôa Orientadora Departamento de Psicologia - PUC-Rio

Profa. Mariângela Silva Monteiro Departamento de Psicologia - PUC-Rio

Profa. Zena Winona Eisenberg Departamento de Educação - PUC-Rio

Profa. Monah Winograd Coordenadora Setorial de Pós-Graduação e Pesquisa do Centro de Teologia e Ciências Humanas - PUC-Rio 
Todos os direitos reservados. É proibida a reprodução total ou parcial do trabalho sem autorização da universidade, da autora e da orientadora.

\section{Patricia Siqueira Oliveira}

Graduou-se em Psicologia no IBMR-Laureate (Instituto Brasileiro de Medicina e Reabilitação) em 2015. Pesquisadora do campo escolar e as relações presentes nesse ambiente. Diversos cursos na área de psicologia infantil, adolescente e adulto e em arte-terapia. Atuante como psicóloga para todas as idades.

Ficha Catalográfica

Oliveira, Patricia Siqueira

A relevância da afetividade nos processos de aprendizagem / Patricia Siqueira Oliveira; orientadora: Luciana Fontes Pessôa. - 2018.

116 f. ; $30 \mathrm{~cm}$

Dissertação (mestrado) - Pontifícia Universidade Católica do Rio de Janeiro, Departamento de Psicologia, 2018.

Inclui bibliografia

1. Psicologia - Teses. 2. Aprendizagem. 3. Relação professor-aluno. 4. Afetividade. 5. Escola. 6. Arte. I. Pessôa, Luciana Fontes. II. Pontifícia Universidade Católica do Rio de Janeiro. Departamento de Psicologia. III. Título. 


\section{Agradecimentos}

Às diretoras e coordenadoras das escolas que realizei a pesquisa. Aos professores e alunos que participaram das entrevistas. Sem esses, não seria possível a realização da mesma.

Ao CNPq, Capes e à PUC-Rio, pelos auxílios concedidos, sem os quais este trabalho não poderia ter sido realizado.

Aos professores da PUC-RJ que ao lecionar as matérias do programa de mestrado contribuíram com os debates e bibliografias sugeridas. À querida professora Mariângela, pelas importantes contribuições, apoio e incentivo.

A minha orientadora Luciana F. Pessôa que trouxe ensinamentos constantes ao longo dessa dissertação.

Ao grupo de estudos e amigas voluntárias que participam do projeto social de psicologia na ONG SBS/OPJ, Yolanda, Najla, Branca, Christiane, Ana Paula, Charllote, Rebeca, Beatriz e outras queridas que trazem a coragem, emoção, doçura, acolhimento e compartilham os seus conhecimentos nas supervisões, encontros e nos atendimentos psicológicos que fazemos nesse espaço. Aprendo muito com elas. Gratidão por esses encontros.

A Sol Mendonça e Marina Souza que tiveram um papel fundamental de atenção e cuidado no processo de finalização desse estudo. Muito obrigada.

Em especial aos professores que passaram pela minha vida e deixaram a "marca" do conhecimento onde percebi que a relação é parte fundamental do aprendizado; Lolita, Claudeli, Adelaide (ensino primário), Maurício e Ana Cristina (ensino fundamental), Carla e Valdete (ensino médio), Teresa, Cadu, Luciana, Tatiana (graduação) me ensinaram além da teoria.

A todos os amigos e familiares que de alguma forma me estimularam e me ajudaram nessa minha jornada que foi o mestrado. Fernanda, Maria Eduarda e Bruno foram e são essenciais para a minha chegada até aqui.

Agradeço, também, ao meu parceiro de vida, Afonso, pelos momentos de apoio e alegria. 


\section{Resumo}

Oliveira, Patricia Siqueira; Pessoa, Luciana Fontes (Orientadora). A relevância da afetividade nos processos de aprendizagem. Rio de Janeiro, 2018. 116p. Dissertação de Mestrado - Departamento de Psicologia, Pontifícia Universidade Católica do Rio de Janeiro.

Esta dissertação tem como objetivo analisar os aspectos emocionais da interação professor-aluno, no processo de aprendizagem, a partir de pesquisa de campo realizada em escolas públicas e particulares da Zona Sul do Rio de Janeiro, nos anos de 2016 e 2017. Os referenciais teóricos-metodológicos foram tecidos com vários autores, especialmente do campo da psicologia, como Lev Vygotsky e Henri Wallon com suas discussões sobre desenvolvimento e aprendizagem; no campo da educação, contribuem as reflexões críticas de Paulo Freire sobre a educação bancária; os pressupostos teóricos de Wallon (1971), e Vygotsky (1984) que buscam reiterar a importância da interação social nos processos de aprendizado. Para Vygotsky (1991), a aprendizagem é construída pelas recombinações realizadas pelo sujeito ativo nos processos culturais e de conhecimento. Wallon (1971) defende que as expressões do sujeito, seus gestos e até mesmo a respiração descompassada podem ser observados e identificados no processo de aprendizagem. Freire (1987) ressalta ainda, a importância do sujeito questionar o que é ensinado. Dessa forma, é possível a ele encontrar um sentido/significado no aprendizado. Um aspecto que emergiu das observações foi o papel da arte na educação. Mesmo não sendo um objetivo desse trabalho, parece ser um tema relevante para estudos posteriores. A arte tem ligação direta com o aprendizado por trazer à tona formas de expressão sem os cerceamentos que, muitas vezes, as teorias impõem. Participaram da pesquisa quarenta e oito alunos e vinte e três professores do $7^{\circ}$ e $9^{\circ}$ ano do Ensino Fundamental II das redes pública e privada. As escolas selecionadas para o estudo são localizadas no bairro de Botafogo, Zona Sul do Rio de Janeiro. Foram realizadas entrevistas com perguntas semiestruturadas e os alunos responderam ao Questionário Sobre o Clima Escolar, Adaptation and preliminary validation evidences of the School Climate Questionnaire - Revised, Elementary and Middle School Version (SCS-MS) (PETRUCCI et. al., 2016) em que foi possível observar pontos como: justiça; ordem e disciplina; envolvimento dos pais; troca de recursos; relações interpessoais dos alunos; e relação aluno-professor. Também foram investigadas as caraterísticas da interação professor-aluno, os aspectos emocionais presentes relacionados com o processo de aprendizado. Outrossim, a motivação do aluno, em sala de aula, foi relatada com o intuito de relacioná-la com os aspectos interacionais. Neste sentido, o papel da arte na aprendizagem foi identificado sendo percebida a importância da prática artística no ambiente escolar. Os resultados da pesquisa de campo deste estudo permitiram a análise da relação dos alunos com a escola e, também, ouvir sobre sentimentos, opiniões e motivações de quem tem tanto a dizer sobre a educação: professores e alunos. Acredita-se que este estudo pode abrir novos horizontes para se repensar os modelos educacionais vigentes que se baseiam em uma educação pouco dialógica, silenciadora e sem participação.

\section{Palavras-chave}

Aprendizagem; relação professor-aluno; afetividade; escola; arte. 


\section{Abstract}

Oliveira, Patricia Siqueira; Pessoa, Luciana Fontes (Orientadora). The relevance of affectivity in the learning processes. Rio de Janeiro, 2018. 116p. Dissertação de Mestrado - Departamento de Psicologia, Pontifícia Universidade Católica do Rio de Janeiro.

This dissertation has the purpose of analyzing the emotional aspects of the teacher-student interaction in the learning process, starting from a field research conducted at public and private schools in the South Side of Rio de Janeiro, in 2016 and 2017. The theoretical-methodological benchmarks have been woven with several authors, especially in the field of Psychology, like Lev Vygotsky and Henri Wallon with their discussion on developing and learning; in the field of education, the contribution comes from Paulo Freire critical thinking on banking education; the theoretical assumptions of Wallon (1971) and Vygotsky (1984), who seek to reiterate the relevance of the social interaction on the learning processes. For Vygotsky (1991), learning is constructed by the recombinations held by the active subject in the cultural and acquiring knowledge processes. Wallon (1971) defends that the subject's expression, his/her gestures and even the out of beat breath can be observed and identified in the learning process. Freire (1987) still stresses the importance of the subject questioning what is taught. Thus it is possible to him/her finding a sense/meaning in learning. One aspect that emerged from the observations was the role of art in education. Even though it is not the purpose of this work, it seems to be a relevant topic for later studies. Art is directly connected to learning because it brings out forms of expression without the curtailment that, many times, theories impose. Forty-eight students and twenty-two teachers of $7^{\text {th }}$ and $9^{\text {th }}$ year of Elementary School II of public and private networks have participated in the survey. Those schools selected to the study are located in Botafogo neighborhood, South side of Rio de Janeiro. Interviews with semi-structured questions have been held, and the students answered the School Climate Questionnaire - Adaptation and preliminary validation evidences of the School Climate Questionnaire - Revised, Elementary and Middle School Version (SCS-MS) (PETRUCCI et. al., 2016) - in which it was possible to observe points like justice, order and discipline; parental involvement; exchange of resources; students interpersonal relations; and student-teacher relation. Characteristics of student-teacher interaction and the present emotional aspects related to the learning process have also been researched. Likewise, the student motivation in classroom has been reported with the purpose of link it with the interaction aspects. In this regard, the role of art in learning has been identified, and the importance of artistic practice in school environment was noticed. The results of the field research of this study have enabled us the analysis of the connection of students with school and, as well, hearing about feelings, opinions and motivations from those who have so much to say on education: teachers and students. It is believed that this study may open new horizons so that the current educational models based on a shortly dialogical, silencer and non-participatory education can be rethought.

\section{Keywords}

Leaning; teacher-student relation; affectivity; school; art. 
"O mundo é salvo todos os dias por pequenos gestos. Diminutos, invisíveis. O mundo é salvo pelo avesso da importância. Pelo antônimo da evidência. O mundo é salvo por um olhar. Que envolve e afaga. Abarca. Resgata.

Reconhece. Salva. Inclui"

(Eliane Brum - A vida que ninguém vê) 


\section{Sumário}

Introdução 10

1. A Afetividade nas Relações de Aprendizagem 18

1.1 Processos de aprendizagem a partir da abordagem sócio histórica de Vygotsky

1.2 Pensando a relação da emoção e da aprendizagem a partir de Henri Wallon

2. A Infância e a Contemporaneidade: Modos de Subjetividade

3. A Escola: Modos de Funcionamento

3.1 Praticas Pedagógicas Contemporâneas: Desafios da prática escolar e o processo de aprendizagem do aluno

4. O Encontro com a Arte no Contexto Escolar

60

5. O Estudo e seus Objetivos

65

6. Metodologia

67

6.1 Procedimentos de análise dos dados $\quad 71$

$\begin{array}{ll}\text { 7. Resultados } & \mathbf{7 2}\end{array}$

$\begin{array}{ll}7.1 \text { Entrevistas } & 72\end{array}$

7.2 Escala do clima escolar QCE-EF $\quad 74$

7.3 Discussão dos Resultados $\quad 77$

$\begin{array}{ll}\text { 7.3.1 O papel da afetividade nos processos de aprendizagem } & 77\end{array}$

7.3.2 O que cada um vê da janela: modos de interação na escola 83

$\begin{array}{ll}\text { 7.3.3 Contextos que afetam e afetividade } & 91\end{array}$

7.3.4 A motivação do aluno e as contribuições da arte para a aprendizagem

$\begin{array}{ll}\text { 8. Considerações Finais } & 101\end{array}$

$\begin{array}{lr}\text { 9. Referências Bibliográficas } & 104\end{array}$

10. Anexos $\quad 108$

$\begin{array}{ll}\text { 10.1 Termo de Assentimento } & 109\end{array}$

10.2 Termo de Consentimento Livre e Esclarecido 111

10.3 Escala Questionário de Clima Escolar - Versão Revisada Ensino Fundamental (QCE-EF 


\section{Lista de tabelas}

Tabela 1: Participantes $\quad 69$

Tabela 2: Entrevistas: Alunos 72

Tabela 3: Entrevistas: Professores 73

Tabela 4: Questionário de Clima Escolar - Versão Revisada Ensino

Fundamental QCE-EF) 75

Tabela 5: Resultados do Questionário de Clima Escolar - Versão

Revisada Ensino Fundamental (QCE-EF) 76 


\section{Introdução}

O estudo dessa pesquisa tem por base meu trabalho de conclusão da graduação em Psicologia, oriundo da disciplina Psicologia Social com a discussão sobre as relações entre afetividade e insucesso escolar. Intitulei minha monografia “O papel da afetividade no processo de aprendizagem e reflexões sobre o fracasso escolar no campo da Psicologia”, concluída em 2014.

Ao assistir a uma aula da disciplina Psicologia Social sobre o texto: “Esporte, formação e sistema conselhos: É possível diálogos? ”, de Espírito Santo et al. (2010), fiquei mobilizada pela discussão da análise da desigualdade nos esportes e de como a escola também é palco de produção de disparidades. Com isso, foi possível perceber a importância das relações na escola e avaliar como um contexto marcado por diferenças poderia contribuir para o fracasso escolar. Naquele momento, percebi que tinha encontrado um tema para minha pesquisa monográfica.

Na disciplina Psicologia Escolar, novas possibilidades de articulação surgiram a partir da leitura de autores como Dayrell (1996) que traz o conceito de escola como "espaço sociocultural”: um espaço ocupado por vários tipos de sujeito, com diferenças étnico-raciais, modos de vida singulares e formas de pensar diferenciadas e que irão juntar-se em sala de aula. A partir desta premissa, pude entender o espaço escolar em outra perspectiva.

Historicamente, a escola se constituiu como espaço "normatizador" e “normalizador”. As diferenças observadas entre alunos de uma mesma turma nem sempre são vistas como enriquecedoras, mas consideradas uma ameaça à ordem. Esta instituição, marcada pela hierarquização e o silenciamento da diversidade é palco de muitos conflitos, produzindo descriminação e exclusão social (PENNA, 2017). Na contramão, a escola pode ser pensada como um espaço de pluralidade democrática, com a valorização dos sujeitos e suas experiências e formas de vida. Assim, ela é tomada como lugar de trocas, criação e transformação de conhecimento. É um espaço que extrapola a dimensão do ensino de um certo conteúdo, sendo uma oportunidade de formação humana, de construção de uma perspectiva crítica sobre o mundo. 
Além da constatação da importância social da escola, a escolha em pesquisar este contexto deve-se à riqueza das experiências vividas, pela quantidade de tempo em que as crianças passam dentro destas instituições. Estes espaços são marcados pelos encontros, pela diversidade cultural, por conflitos, disputas, namoros, paqueras e muitas conversas em sala de aula. Diferentes modos de se relacionar com a escola são materializados no cotidiano. O processo educativo envolve estas múltiplas formas, e também diferentes atores sociais que agem sobre o espaço em que passam boa parte de sua vida. Neste ponto, a escola nem sempre apoia as relações, as descobertas, as aprendizagens, desestimulando as interações. As concepções que orientam o trabalho pedagógico e a organização dos espaços educativos são, muitas vezes, limitadores do encontro entre as crianças e destas com os adultos (FRIGOTTO, 2017).

Partindo do contexto apresentado, essa dissertação tem como objetivo analisar o papel da afetividade no processo de aprendizagem, reunindo o estudo teórico com a prática de campo, por meio de encontros regulares com o intuito de entrevistar professores e alunos em suas práticas escolares cotidianas.

Para enfrentar este desafio, foram definidos os seguintes objetivos específicos: identificar caraterísticas da interação professor-aluno; bem como os aspectos emocionais presentes nesta interação a fim de relacioná-los com o processo de aprendizado. Outrossim, identificar como a motivação do aluno em sala de aula interfere nas experiências de aquisição de novos conhecimentos.

A partir desses objetivos, surgiram alguns questionamentos a serem elucidados. Como seria a entrada nas escolas? Os professores e as crianças seriam receptivos a alguém desconhecido? Considerando o tema amplo, como formular as perguntas inserindo-as na abordagem que este trabalho demandava?

Para responder, foi estabelecido que escolas públicas e particulares deveriam ser visitadas pois assim poderia se alcançar uma diversidade maior de entrevistados. A escolha das turmas do $7^{\circ}$ e do $9^{\circ}$ (sétimo e nono) anos como objeto de estudo veio com a hipótese de que alunos do ensino fundamental II estariam mais preparados para o entendimento da proposta. Neste contexto, a importância da voz dos alunos foi colocada como fator primordial para que os mesmos participassem das entrevistas e, bem como os professores do mesmo segmento ( $7^{\circ}$ e $9^{\circ}$ ano) com o intuito de conseguir a análise interrelacional. Outro questionamento se deu quanto às diferenças de vínculos entre alunos e professores 
do $7^{\circ}$ ano (o segundo ano do Ensino Fundamental II) e do $9^{\circ}$ ano, (o último ano deste segmento). Neste caso, os vínculos seriam desiguais?

Precursor na teoria psicológica histórico-cultural, o bielo-russo Vygotsky (1991) traz que o aprendizado começa muito antes da entrada da criança na escola. Contudo, as possibilidades de encontro com o outro, de apropriação e criação da cultura são bastante significativas. No processo de desenvolvimento, a criança interage com o meio, através de orientações e direcionamentos, até conseguir realizar a atividade proposta sozinha. Isso independe de idade e diversifica-se de acordo com a qualidade da interação da criança com o ambiente. Vygotsky (1991) enfatiza que o aprendizado e o desenvolvimento infantil estão atrelados à influência do afeto. A relação de atenção e sensibilidade do professor com o aluno, traduzida em afeto positivo, em sala de aula, pode facilitar o processo de aprendizagem.

Dentro da teoria vygotskiana, Oliveira (1992) também traz contribuições nos aspectos afetivos nas relações dos sujeitos com o campo educacional. "Os processos pelos quais o afeto e o intelecto se desenvolvem estão inteiramente enraizados em suas inter-relações e influências mútuas” (OLIVEIRA, 1992, p. 76).

Para Vygotsky (2001), pensar na separação do afeto e do intelecto é dissociar o sujeito da sua ação, de suas práticas no mundo. É pensá-lo distante das suas motivações, dos seus interesses e/ou do que lhe é influenciável. Raciocinar dessa forma é excluir a transformação nos modos de pensar e agir.

Sob os aspectos teóricos de Wallon, Mahoney (2010) aborda o entendimento da criança na sua totalidade. É necessário que se olhe para as áreas cognitivas, afetivas e motoras, em conjunto. Encarar o processo de aprendizagem desse modo é buscar a integralidade do aluno no seu processo escolar. Observar como a criança responde no processo é uma forma de perceber como ela está integrando "os recursos de que dispõe”.

Nessa integração das áreas que compõem o sujeito, Wallon (1968) exemplifica que a união da emoção com o aspecto cognitivo, demonstrada de forma abrupta, por meio de gestos ou sentimentos aflorados, tende, ao longo do tempo, em contato com o seu meio e de forma mútua, a alcançar o controle das reações até tomar o lugar do equilíbrio. 
Mahoney (2004), ainda dentro desse contexto walloniano, escreve sobre o constante processo de aprendizagem, na relação entre diferentes sujeitos em um mesmo meio, trazendo a sociabilidade como fator "natural" do aprendizado. A presença do outro nesse processo se torna “indispensável e primordial'.

No desdobramento das relações, um ponto fundamental é a autoestima do aluno com dificuldades no desenvolvimento escolar. Uma vez que não consegue acompanhar as aulas e sentindo-se em uma posição inferior à dos colegas da turma, alunos que experimentam obstáculos no processo de escolarização constroem uma ideia negativa sobre si, sendo essa dificuldade, muitas vezes, enfatizada como um destoamento e não como necessidade de suporte. O papel de alunos e professores está em construção no processo escolar (DAYRELL,1996). Bagunceiro, bom ou mau aluno, problemático, hiperativo, tímido, esforçado, uma vez classificados, ficam rotulados no decorrer de um ano inteiro. Estereótipos negativos e positivos influenciarão os alunos em toda a sua estadia na escola; sendo que os negativos, provavelmente, acarretarão em baixa autoestima no aluno e, consequentemente, em um desempenho escolar fracassado. O emprego de adjetivos como "bom" para os alunos com melhores notas e "mau" para os que têm as notas mais baixas é uma forma reducionista e limitadora de enquadrá-los e suprimir todo o potencial que eles podem vir a desenvolver. Com esses adjetivos, serão feitos enquadramentos que não ajudarão em uma análise melhor para este aluno. Os rótulos "bom” e "mau” para o aluno criam uma forte dicotomia no ambiente escolar onde pode existir algo criado apenas por um olhar ou um ideal de aluno construído pelo professor (DAYRELL,1996).

Utilizando-se de uma normalidade baseada em "critérios ou normas características da idade”, retirando a possibilidade de se levar em conta “idiossincrasias individuais”, ocorre os enquadramentos de alunos em perfis predeterminados. Castro (1999) entende que, dessa forma, “a noção de criança normal apoia-se sobre um mecanismo de minimização das diferenças entre os sujeitos e maximização das semelhanças” (CASTRO, 1999, p. 24).

Assim, a escola tem se configurado como espaço de pouca liberdade, com poucas oportunidades de brincadeira, de distração como estratégia de fruição. A ênfase em provas, vestibulares engessam a rotina, dando pouca abertura para os afetos, para as expressões. Num contexto fechado, quem não se enquadra sofre o risco de sofrer com estereótipos, rótulos, com a medicalização da vida. O não 
aprender não é olhado a partir da própria escola, mas situado numa suposta dificuldade do sujeito, como é o caso da falta de atenção e o comportamento inquieto entendido como um transtorno (MEIRA, 2012). Aprender está muito mais ligado a uma ideia de reprodução, de responder questões de forma correta, do que a um processo inventivo, problematizador. Este estudo assume o posicionamento de que a diversidade deve ser incorporada ao processo de aprendizagem e que o aluno seja participante ativo, autor das suas experiências de aprendizagem.

Freire (1987) nos ajuda a problematizar a escola com sua reflexão sobre a “educação bancária”. Ele critica esse modelo escolar baseado numa visão linear e cumulativa do processo de aprendizagem, no qual os professores são os detentores do saber, e os alunos, os que vão receber, de forma passiva, os conhecimentos. Dentro dessa lógica, não há espaço para a troca, para a invenção, para a criatividade, para a pluralidade de saberes. Para o autor, uma educação libertária compartilha de uma concepção de aprender que demanda uma postura reflexiva, que é construída ativamente pelos sujeitos e tem a dialógica como princípio para a construção do “pensar verdadeiro” e do “pensar crítico” (FREIRE, 1987).

A partir do que foi apresentado, entende-se a relevância da psicologia escolar e dos seus estudos como atuação importante dentro da escola para o bemestar de todos. Acredita-se, também, na necessidade de um olhar crítico e comprometido com o entendimento das diferenças como parte singular de cada sujeito e, desse modo, na necessidade de trabalhar as relações de todos os atores presentes no contexto escolar. Guzzo et al. (2010) traz como função do psicólogo escolar:

Contribuir, junto com educadores, para a promoção da aprendizagem e do desenvolvimento das crianças a partir de uma perspectiva mais integral do sujeito do que vem enfatizando a escola. Ou seja, além do desenvolvimento cognitivo, deve-se promover o desenvolvimento emocional, social e motor por meio de intervenção com as crianças, suas famílias e a comunidade (GUZZO et al., 2010).

A Psicologia é de fundamental importância para o desenvolvimento e entendimento da escola como um espaço mais amplo do que apenas de ensino. A presença de um olhar sensível através do qual pode-se promover mudanças, incluindo debates e reflexões sobre a forma de pensar e agir de professores e alunos, pode ser um importante ponto de partida neste cenário. 
A Psicologia em muito contribuiu com uma perspectiva individualizante, localizando os problemas escolares nos indivíduos a partir de um modelo de ideal, de normalidade. Também responsabilizou as relações familiares, nos contextos pobres, como inadequados, tóxicos ao desenvolvimento. Patto (1997) sinaliza essa perspectiva realizada pela Psicologia de forma "sutil”. É necessário que se fique atento para não seguirmos esse caminho de diagnósticos sociais e culpas individuais de fracassos na escola. Ainda hoje, mesmo com os avanços no campo da Psicologia, é comum a explicação das dificuldades escolares por conta de uma realidade suposta de privação cultural (PATTO, 1997).

Um outro aspecto que emergiu do campo foi o lugar das artes na aprendizagem. Mesmo não sendo um objetivo desse estudo, o tema mostrou-se significativo. As relações observadas fortaleceram a compreensão das artes como grande forma de expressão, podendo contribuir no aprendizado de alunos inseridos em atividades artísticas. A relação com a arte vai além de apropriação da cultura, é um processo inventivo, de constituição subjetiva, de construção de sentidos, é uma forma de desenvolvimento das funções psicológicas superiores e de relação com o conhecimento, a socialização e o enriquecimento cultural. Assim, surgem novas possibilidades para lidar com o cotidiano, com tensões dentro e fora do contexto escolar (FREITAS, 1998).

Para analisar e aprofundar o papel da afetividade no processo de aprendizagem, autores como L. S. Vygotsky e H. Wallon embasaram a fundamentação teórica desse trabalho. Vygotsky (1984) ressalta que os sujeitos, de forma ativa, se apropriam e criam cultura. Assim, o sujeito é participativo em seu processo de aprendizagem. Em um contexto escolar, a partir de Vygotsky, as interações são o eixo do trabalho educativo. Elas farão a diferença na vida da criança, sendo uma oportunidade muito especial de aprendizado.

Na mesma direção, Wallon (1971) considera as emoções para pensar o tema da aprendizagem, destacando seu papel nas interações entres as crianças. Para ele, a emoção trará a atenção da criança para o aprendizado. O autor diz ainda que a relação com o meio e com as pessoas fará dessa interação satisfatória ou não. A construção da personalidade da criança é diretamente afetada pelo mundo que é apresentado a ela através das relações estabelecidas.

Também será apresentada na fundamentação teórica desse trabalho uma revisão sobre as concepções de infância na contemporaneidade, já que se entende 
que estas concepções produzem realidades e marcam as relações no interior da escola. Para isso, serão apresentados os seguintes autores: Arroyo (2008) com sua discussão sobre infância na contemporaneidade, problematizando a utilização de um modelo de infância; e Lightfoot e Valsiner (1992) pensando a infância como uma construção histórica. O primeiro autor ressalta que a diversidade infantil está presente na escola, trazendo à tona as diferenças; sendo tarefa do docente lidar com tal diversidade. Lightfoot e Valsiner (1992) apontam que o olhar mais sensível para as especificidades da criança é recente. A chegada do século XX, através das mudanças nos modos de se vestir, nas artes e no conceito de criança dentro da escola, trouxe novas compreensões sobre a infância.

Na contextualização do diálogo com a teoria e o campo, o trabalho está organizado em quatro capítulos. O Capítulo 1 aborda a afetividade nas relações de aprendizagem, a partir dos teóricos Vygotsky e Wallon. Como o afeto e a emoção estão presentes no contexto do sujeito nas suas relações interpessoais, trazendo os processos de aprendizagem como enfoque e também no ambiente em que estão inseridos.

O capítulo 2 traz a construção do que se entende por infância e o seu modo de atuar até os dias de hoje. A subjetividade do sujeito faz-se entender que os perfis únicos não cabem nos dias atuais, trazendo pontos de reflexão para a pedagogia. O consumo das crianças atravessa a escola nos modos de existir dos alunos e, com isso, essa reflexão se faz presente neste capítulo.

O capítulo 3 aborda os modos de funcionamento da escola. A partir da perspectiva de que a escola deve ser plural nos seus modos de entender os sujeitos que estão inseridos no contexto, faz-se a discussão sobre como os aspectos físicos e de entendimentos sobre os sujeitos abarcam as diferenças. Discute-se, também, as formas e os desafios do aprendizado a partir das subjetividades dos atuantes na escola. Como a cultura e a construção do que é ser no mundo se inserem dentro da sala de aula. E, sob essa perspectiva, a necessidade de um saber crítico e questionador se torna necessário no campo escolar.

O capítulo 4 se impôs como reflexão do tema a ser estudado. A necessidade de trazer as práticas artísticas na escola estava inicialmente no préprojeto. Na percepção da amplitude do tema, a reflexão das práticas artísticas demonstrou ser importante quando o assunto é a educação, porém difícil de ser contextualizada nesta dissertação que se propôs a analisar e investigar a 
afetividade dentro da relação professor-aluno. Entende-se que a criatividade e a sensibilidade devem estar presentes no processo de aprendizagem, possibilitando outras formas de sentido e linguagem para os sujeitos que estão dentro da escola. Esse capítulo abre caminhos para estudos mais amplos posteriores a esta dissertação.

A aprendizagem é um processo complexo, envolve muitas variáveis, e muitas vezes vem sendo tratada de forma simplista, responsabilizando professores e/ou alunos pelos insucessos. Esse trabalho traz as contribuições dos teóricos da psicologia do desenvolvimento e da aprendizagem, mas é importante que o debate seja feito também em sua dimensão política.

Nos resultados e suas discussões, as falas dos alunos e professores entrevistados se fazem presente de forma a exemplificar a relação entre a afetividade e o processo de aprendizado. Contudo, foi possível perceber que todas as interações afetivas entre os atuantes, seja nos ambientes comuns da escola ou nas salas de aula, influenciam diretamente nessa questão.

Nas considerações finais, são trazidos os entendimentos da pesquisa no contexto de falas dos principais atuantes na escola, professores e alunos. Percebese que, quando o assunto é educação, é necessário um olhar crítico e sensível. Nas percepções da pesquisa, a afetividade positiva é essencial para todos os presentes no campo escolar uma vez que este espaço passa a ter um novo sentido na relação com o processo de aprendizado. 


\section{A afetividade nas relações de aprendizagem}

Este capítulo situa o tema da afetividade, a partir das contribuições da psicologia histórico-cultural, trazendo a relação do sujeito com o seu meio, através das mediações pelos signos, outros sujeitos e a cultura. Em seguida, discute a compreensão da afetividade e seus desdobramentos para o desenvolvimento infantil, tendo como referência Henri Wallon $(1968,1971)$.

O desenvolvimento infantil se dá por trocas nas atividades psíquicas e na relação que se constrói com o mundo. Dessa forma, os pensamentos são expressos em palavras por significados. A “essência” do aprendizado está na generalização, ou seja, a criança vai de uma generalização à outra, e assim entra em contato com o processo de formação dos significados, aqueles que Vygotsky (2001) chamará de “os verdadeiros conceitos”, importante na organização do pensamento (VYGOTSKY, 2001). As explicações que embasam a construção do pensamento não estão dissociadas. A capacidade das transformações do pensamento se dá pelos interesses, motivações e vontades que ocorrem ao longo do processo de aprendizagem. A partir desse contexto, a junção dos processos afetivos e intelectuais ocorre por um "sistema dinâmico que representa essa unidade" (VYGOSTKY, 2001, p. 16).

Tanto Vygotsky (2001) quanto Wallon (1971) destacam o papel da afetividade na socialização e na produção de significação, sendo interlocutores importantes para se pensar o tema da relação professor-aluno.

Para Vygotsky (2001), uma questão emblemática da psicologia tradicional é separar o intelecto do afeto e das vontades na consciência do sujeito. Ser e estar no mundo requer o envolvimento através dos interesses, vontades e motivações no percurso de vida. A fim de que seja possível uma análise elucidativa das práticas pedagógicas, Rego (1995) enfatiza, em vários momentos, dentro da teoria vygotskiana, que é inevitável a união dos aspectos intelectuais e afetivos no estudo do funcionamento psicológico.

Com base em Wallon (1971), que traz a perspectiva da união dos aspectos motores incidindo sobre os aspectos emocionais (e vice-versa), proporcionando, 
assim, a evolução psicológica da criança, as sensações que a criança recebe vêm por reflexos motores, sendo a postura e os gestos exemplos destes reflexos. Para Wallon (1971), a emoção tem um caráter contagioso na relação com o outro.

Dentro desse contexto, Dantas (1992) explica sobre como a emoção tem papel fundamental na sobrevivência do bebê, por exemplo. Choros e berros gerados por alguma inquietação causam grande impacto. A importância de se compreender a emoção traz o direcionamento para o campo escolar de que "a educação da emoção deve ser incluída entre os propósitos da ação pedagógica, o que supõe o conhecimento íntimo do seu modo de funcionamento” (DANTAS, 1992, p. 89).

A afetividade e a inteligência estão ligadas na teoria de Wallon, conforme cita Dantas (1992) sobre a interação dessas áreas. Nas crianças, inicialmente, a afetividade pode vir expressa por reações emocionais descompassadas. O equilíbrio vem também com o auxílio do sujeito que se relaciona com a criança. A significação e a construção do eu virá nessa relação, demonstrando, assim, a importância do social nos aspectos afetivos e de inteligência.

No entendimento da importância de se perceber a criança dentro da sua integralidade no seu desenvolvimento, o estudo da afetividade nos processos de aprendizagem torna-se primordial.

\section{1}

\section{Processos de aprendizagem a partir da abordagem sócio histórica de} Vygotsky

Lev S. Vygotsky nasceu no ano 1896, na cidade de Orsha, na Bielo Rússia. Teve uma formação multidisciplinar graduando-se em Literatura e Direito. Chegou a matricular-se no curso de Medicina, mas optou pela História da Arte e pelos estudos voltados para a Psicologia. Tornou-se professor de Literatura e Psicologia e coordenou o Departamento de Teatro da escola em que dava aula, o que culminou na publicação da sua primeira pesquisa em Literatura, mais tarde reeditada com o título de A Psicologia da Arte.

Trabalhou em Moscou, no Instituto de Psicologia, e logo criou o Instituto de Estudos das Deficiências. Teve uma morte prematura aos 38 anos de idade. No Brasil, teve o seu primeiro livro publicado em 1984, A Formação Social da 
Mente. Trouxe importantes contribuições para a educação com conceitos sobre o desenvolvimento infantil e a relação da criança com o meio que a cerca. A importância da mediação e a zona de desenvolvimento proximal são conceitos fundamentais para se entender o aprendizado na teoria do autor (VYGOTSKY, 1989).

Como entendimento do leitor a esse estudo, um contraponto foi apresentado pela autora Prestes (2010), que estudou as traduções feitas da língua materna de Vygotsky (o Russo) no Brasil. Ela faz críticas às traduções e aponta possibilidades de distorções para alguns conceitos importantes na obra do autor. O livro, A Formação Social da Mente é citado como uma obra que teve alguns conceitos alterados pela dificuldade da tradução do original para o Português. Em contrapartida, a autora adverte que os organizadores do livro assumem o risco, no prefácio, e afirmam o compromisso em reproduzir os conceitos do autor da melhor maneira possível. Nesse estudo, optou-se, ainda assim, por usar a obra por trazer conceitos importantes da teoria vygotskyana que atendem as necessidades dessa pesquisa.

Vygotsky (1991) teve influência das concepções materialistas históricas de Marx e Engels. A teoria marxista, também conhecida como materialismo histórico, influenciou a teoria de Vygotsky quando afirmam que mudanças históricas coletivas tiveram reflexo na consciência e no comportamento individual. Vygotsky buscou a repercussão desse contexto na relação do trato psicológico. Na relação com a teoria de Engel, o autor procurou mostrar que à medida que o homem transforma a natureza, ele está transformando a si mesmo. Engel, Marx e Vygotsky entendem que “o mecanismo de mudança individual ao longo do desenvolvimento tem sua raiz na sociedade e na cultura” (VYGOTSKY, 1991, p.11).

As funções psicológicas superiores (percepção, memória, atenção, pensamento) têm um destaque nas crianças que estão em fase escolar. Os movimentos de desenvolvimento dessas áreas se dão por processos de intelectualização que estão ocorrendo nesse período, em que a tomada de consciência é maior do que em idades menores (VYGOTSKY, 2001 p. 282).

A teoria de Vygotsky valoriza as interações sociais, destacando fatores endógenos e exógenos para o desenvolvimento. Para ele, é na relação com o mundo que os conhecimentos são construídos. Seus estudos dão pistas para se 
compreender como os sujeitos se formam no contexto social de que participam desde o nascimento. $\mathrm{O}$ indivíduo em contato com a cultura apropria-se e age, ou seja, produz cultura (FREITAS, 1998). Dessa forma, o mundo psíquico não está pronto previamente, não nasce com as pessoas, como acreditavam os inatistas. Também não se constitui como um “pacote pronto" do ambiente, como afirmavam os empiristas. É na história, imersos na cultura, de forma inventiva, que os sujeitos se constituem e criam o mundo (OLIVEIRA, 1997).

Vygotsky, com sua tentativa de construir uma nova psicologia, aponta para os seguintes planos genéticos de desenvolvimento: filogênese (define limites e possibilidades da espécie); ontogênese (o desenvolvimento do ser); sóciogênese (a história cultural); microgênese (cada fenômeno psicológico tem sua própria história). Destaca-se a compreensão da cultura como alargador das potencialidades humanas, bem como da singularidade das experiências. O autor atenta para o nascimento cultural a partir de um substrato biológico, analisando como o social constitui o mundo subjetivo, sem que se dilua a singularidade (OLIVEIRA, 1997).

A dupla natureza do ser humano, membro de uma espécie e de um grupo cultural, permite duas afirmações: que o funcionamento psicológico tem base biológica; e que a relação com o mundo é mediada por instrumentos e símbolos desenvolvidos culturalmente. Embora sejam construídos de forma coletiva, os significados, presentes nas formas de organizar a realidade, são transformados pelas pessoas que atribuem a esses significados suas histórias e experiências. Somos seres únicos e, mesmo compartilhando experiências, cada um tem uma forma própria, singular, de ver e se relacionar com o mundo. Um modo que é resultado da relação entre o meio, a cultura, nossos processos internos, nossa subjetividade (OLIVEIRA, 1992).

De um lado, o conhecimento do cérebro como substrato material da atividade psicológica e, de outro lado, a cultura como parte essencial da constituição do ser humano, num processo em que o biológico se transforma em sócio histórico (OLIVEIRA, 1992, p. 33).

Dentro dessa perspectiva, o olhar para o desenvolvimento não se dá a partir de etapas ou de uma forma unidirecional (VYGOTSKY, 1991). O desenvolvimento, para Vygotsky, tem um enfoque pluridimensional e é atravessado pela cultura em que estamos inseridos. O olhar dos adultos que 
interagem com as crianças marca as subjetividades infantis. E esse movimento é duplo, adultos e crianças, vão se constituindo agindo sobre o mundo, produzindo sentidos (SOUZA, 1998).

Na criança pequena, para que o desenvolvimento ocorra, é necessária a mediação do adulto no seu processo de elaboração e de aprendizagem. Pode-se dizer que o aprendizado ocorre "de fora para dentro". Para Vygotsky, todo aprendizado, antes de se tornar algo intrasubjetivo, foi uma experiência intersubjetiva que aconteceu entre as partes, através das interações. Isto reafirma como são fundamentais, tanto para o desenvolvimento quanto para a aprendizagem, as relações que a criança estabelece com as outras pessoas, sejam crianças ou adultos (FREITAS, 1998).

Para interagir com o mundo, é preciso uma representação simbólica da realidade que se apresenta. Tal representação é importante no desenvolvimento quando falta o conhecimento prévio sobre determinado assunto. Nesse momento, o simbólico tem um papel importante na mediação da realidade. O simbólico é construído pela cultura e pelos modos de interação presentes no cotidiano do sujeito. Dessa forma, o homem se relaciona com as coisas do mundo de forma mediada, usando instrumentos e signos (OLIVEIRA, 1992).

Essa mediação para Vygotsky (1991) aponta para uma transição da ação de base biológica como, por exemplo, movimentos fortuitos dos bebês, reflexos, para uma ação de base social, como o encontro de formas simbólicas de comunicação do adulto. Outra discussão feita pelo autor, que vai na mesma direção, refere-se aos estímulos auxiliares, quando uma criança deixa de ser impulsionada apenas por necessidades biológicas para ser direcionada por reações culturais. As construções subjetivas e abstratas serão externalizadas através de signos linguísticos, culturalmente construídos nas relações como um todo. A criança passa a ser capaz de expressar com o auxílio da linguagem uma reação de conduta volitiva (VYGOTSKY, 1991).

A linguagem auxiliará a criança a adquirir conhecimento através da manipulação de um objeto diferente e, sendo orientada pelo adulto, a criança pode imitá-lo e ressignificar o objeto, apropriando-se desse conhecimento. Vygotsky postula a importância da linguagem como instrumento culturalmente construído, tendo duas funções: a de intercâmbio social e a de pensamento generalizante (OLIVEIRA, 1997). Dessa forma, quanto mais a criança reelaborar os códigos 
culturais, mais ela terá desenvoltura para realizar as atividades propostas (OLIVEIRA, 1992; FREITAS, 1998). Quando a criança consegue colocar uma ideia em prática e se expressar através da linguagem verbal, seu desenvolvimento intelectual apresenta maior complexidade, seu pensamento torna-se verbal e a fala, racional. A maneira com que a criança se organiza no seu ambiente tem a ver com o modo que ela expressa seus desejos, e assim vai produzindo suas relações com o mundo (VYGOTSKY, 1991). Diante do exposto, observa-se que a linguagem, sistema simbólico básico dos grupos humanos, "fornece os conceitos e as formas de organização do real que constituem a mediação entre o sujeito e o objeto de conhecimento” (OLIVEIRA, 1992, p. 80).

Na teoria de Vygotsky, há uma separação de dois componentes da palavra: o significado propriamente dito e o sentido. O primeiro é caracterizado por uma estabilidade, compartilhado por um grupo social e que permite a generalização, "refere-se ao sistema de relações objetivas que se formou no processo de desenvolvimento da palavra” (OLIVEIRA, 1992, p. 81). Já o sentido da palavra, associa o significado objetivo aos afetos do indivíduo e aos motivos pessoais dos seus usuários (OLIVEIRA, 1992, p. 81).

Vygotsky (1991), em seus escritos dos anos 1920 e 1930, já propunha uma indissociação do afeto e da cognição nas relações de aprendizagem - as emoções como mobilizadoras para a ação. Para o autor, esse aprendizado acontece desde o nascimento da criança. Sobre esse tema, é importante ressaltar que os estudos de Vygotsky (1991) encontram ressonância nos trabalhos de Wallon (1971), autor que será abordado no item a seguir.

Freitas (1998) afirma que para a compreensão ir além das falas, do dito, é preciso observar os vínculos estabelecidos com quem se fala, a maneira como se transmite essa fala, a entonação, a motivação. “A linguagem é sempre polissêmica, sempre requerendo interpretação com base em fatores linguísticos e extralinguísticos” (OLIVEIRA, 1992, p. 82). A fala tem sentido, direção, é marcada por afetos, busca estabelecer vínculos, expressa visões de mundo (FREITAS, 1998). De acordo com Freitas (1998), em termos do desenvolvimento da linguagem, é preciso perceber como essa criança se expressa nas suas relações, pois, dessa forma, ela estará demonstrando seu mundo interno e a sua interação com ele. A fala é a expressão do mundo interior da criança, das suas motivações. 
Assim, a palavra é o elo da criança com suas relações socais e também em seus processos de subjetividade e consciência. As palavras participam do desenvolvimento do pensamento, bem como da construção histórica da consciência humana. As formas de expressão pela palavra são ideológicas, expressão de uma visão de mundo que as crianças vão construindo ao longo de sua trajetória, de forma singular, por meio de elaboração das situações vivenciadas no cotidiano. A criança que desenvolve sua fala, desenvolve também sua percepção em relação às coisas que a rodeia. Vygotsky (1991) ressalta a importância da fala e da ação, sinalizando que as duas caminham juntas e têm igual importância.

A criança que fala tem, dessa forma, a capacidade de dirigir sua atenção de uma maneira dinâmica. Ele pode perceber mudanças na sua situação imediata do ponto de vista de suas atividades passadas, e pode agir no presente com a perspectiva do futuro (VYGOTSKY, 1991, p. 27).

Outro aspecto que merece ser destacado é a relação entre desenvolvimento e aprendizagem. De acordo com Vygotsky (1991), a aprendizagem promove o desenvolvimento, não se constituindo como um processo fixo, fechado.

Assim, a aprendizagem é alçada a uma posição de extrema importância, na medida em que se constitui em condição fundamental para o desenvolvimento das características humanas não naturais, mas formadas historicamente, o que equivale dizer, para o ser e agir no mundo (FREITAS, 1998).

O aprendizado, para Vygotsky (1991), extrapola o sentido de "processo de maturação”. Aprender é uma experiência relacional, inventiva, marcada pela cultura. Para o autor, o aprendizado começa antes da escola, mas este ambiente proporciona um impulso importante no que se refere ao conhecimento científico.

Sobre o aprendizado, comenta:

(...) o aprendizado não é desenvolvimento; entretanto, o aprendizado adequadamente organizado resulta em desenvolvimento mental e põe em movimento vários processos de desenvolvimento que, de outra forma, seriam impossíveis de acontecer. Assim, o aprendizado é um aspecto necessário e universal do processo de desenvolvimento das funções psicológicas culturalmente organizadas e especificamente humanas (VYGOTSKY, 2007, p. 103).

Vygotsky (2007) avança afirmando que não se pode limitar ao que a criança já sabe fazer, e sim ao que ela futuramente é capaz de aprender. Dessa forma, tem-se uma visão prospectiva. A aprendizagem propicia desenvolvimento; 
e o inverso também é verdadeiro. O autor propõe o conceito de zona de desenvolvimento proximal:

(...) é a distância entre o nível de desenvolvimento real, que se costuma determinar através da solução independente de problemas, e o nível de desenvolvimento potencial, determinado através da solução de problemas sob a orientação de um adulto ou em colaboração com companheiros mais capazes (VYGOTSKY, 2007, p. 97).

Assim, a distância simbólica entre o desenvolvimento potencial e o desenvolvimento real é a zona de desenvolvimento proximal, definida por Vygotsky (1984). De acordo com os pressupostos do autor, na zona do desenvolvimento proximal, a prática sobrepõe o pensamento (VYGOTSKY, 1984). “A zona de desenvolvimento proximal provê psicólogos e educadores de um instrumento através do qual se pode entender o curso interno do desenvolvimento” (VYGOTSKY, 2007, p. 98).

O aprendizado se efetivará quando a criança estiver preparada cognitivamente para internalizar certos conteúdos, que se tornarão “aquisições do desenvolvimento independente da criança” (VYGOTSKY, 2007, p. 103). Em relação à escola, Vygotsky vai pensar questões sobre a intervenção pedagógica, sobre o papel do professor. Ele deverá estar atento a essa criança, pois o que ela está aprendendo será evidenciado nas brincadeiras, nas interações com os outros alunos, nas dúvidas. Em diferentes formas de expressão têm-se pistas do processo de aprendizagem vivido. O olhar e a atenção do professor farão toda a diferença para o ensino e a aprendizagem (FREITAS, 1998).

A complexidade crescente do comportamento das crianças reflete-se na mudança dos meios que elas usam para realizar novas tarefas e na correspondente reconstrução de seus processos psicológicos (VYGOSTKY, 1991, p. 51).

Dentro dessa perspectiva, a escola é um espaço privilegiado de partilha de experiências, tomando os sujeitos como ativos, produtores de cultura. Para que ocorra esse processo, é preciso que o ambiente esteja em condições adequadas e favoreça as relações sociais (ISAIA, 1998). Assim, o sujeito é participativo em seu processo cultural e de aprendizagem. A maneira como ele responde ao processo de aprendizagem indica como se deram suas experiências de socialização, suas formas de relação com o outro. Nesse sentido, o processo de 
aprendizagem sempre necessita do outro para mediação com o conhecimento, e também da ação do próprio sujeito.

As elaborações que a criança realiza nas situações de conflitos deverão ser observadas com mais atenção, já que podem estar sinalizando como esta criança está internalizando o conhecimento. Sabe-se que a capacidade criativa infantil é extensa e, portanto, o professor deve dar o suporte para a criança enfrentar um conflito ou obstáculo que surja e não fazer por ela (VYGOTSKY, 1991). Situações diferentes no cotidiano da criança são importantes que sejam provocadas. Dessa forma, ela desenvolve uma motivação na tentativa de buscar meios para conseguir lidar com as diferentes situações. Os processos de independência e inteligência (cognitivo, emocional e social) dependerão dessas situações de desequilíbrios e do apoio que a criança terá para descobrir novas maneiras de agir mediante diferentes situações que enfrentará ao longo do seu desenvolvimento.

De acordo com Vygotsky (1991), a criança, no geral, responde as situações novas de forma mais suscetível por ser uma novidade, diferente de um adulto que, possivelmente, já terá um conhecimento prévio sobre e tenderá a se limitar aos recursos que acredita que tem. Usando essa facilidade da criança na escola, podemos entender que o aprender através de novas situações poderá facilitar todo o processo de ensino e de aprendizagem. Se for evitado o enquadramento do conhecimento dentro dos parâmetros ou preconceitos do adulto, o aprender poderá acontecer de forma tranquila e satisfatória. Deixar a criança mostrar como ela está experimentando o processo educativo, e a partir daí, desenvolver estratégias para continuar o processo, deve ser uma opção em sala de aula, atentando para as necessidades e desejos de cada aluno e respeitando as singularidades (FREITAS, 1998).

Ao falar de conhecimentos infantis, pode-se destacar a diferença dos conceitos adquiridos no cotidiano ou espontaneamente, que ocorrem nas interações sociais, e "os conceitos científicos”, que são aqueles que ocorrem na escola e têm por base o conhecimento letrado (OLIVEIRA,1992). Dentro do contexto vygotskyano, os conceitos são apropriados ao longo do desenvolvimento infantil. Existe um processo quando a criança se depara com o "conceito cotidiano” até conseguir operacionalizar esses conhecimentos, que tem por base “a experiência pessoal gerada em experiências concretas” (OLIVEIRA, 1992, p. 
32). Vygotsky (1989) cita que: "É preciso que o desenvolvimento de um conceito espontâneo tenha alcançado certo nível para que a criança possa absorver um conceito cientifico correlato”.

Desse modo, o desenvolvimento do aprendizado está relacionado com os conceitos “científicos” e “espontâneos” (ou cotidianos) e da apropriação dos mesmos. O envolvimento de significação e sentido, a partir da interação das formações dos conceitos, abrirá caminhos para novos conhecimentos. Nesse contexto, aspectos psicológicos estarão acionados para que o aprendizado aconteça: a capacidade de abstração e discriminação, atenção e memória (OLIVEIRA, 1992).

Observa-se que quanto mais a criança está engajada no seu desenvolvimento, mais ele será proveitoso. Vygotsky (1991) traz a importância da inclusão de certos obstáculos ou dificuldades para que a criança saia um pouco da rotina e aprenda a lidar com outros tipos de situações. Com isso, de acordo com os pressupostos do autor, as crianças podem desenvolver novas habilidades mediante essas situações.

Em relação aos problemas no processo ensino-aprendizagem, estes “não podem ser resolvidos sem uma análise da relação aprendizagemdesenvolvimento” (VYGOTSKY, 1984). Ao analisarmos o desenvolvimento escolar com enfoque na criança e em suas relações, podemos vincular esse processo de interação com o desenvolvimento das funções mentais superiores memória voluntária, atenção seletiva e pensamento lógico (VYGOTSKY, 1991). Essas funções exigem uma aquisição de conhecimento para se desenvolver a qual virá por intermédio dos que participam e se relacionam com a criança, porquanto inseridos em seu contexto social e cultural.

A partir da perspectiva histórico-cultural, percebe-se a riqueza das experiências vividas no interior da escola, de como os sujeitos se constituem nas relações, de como as trocas entre as crianças são oportunidades de aprendizagem, da importância do papel do educador na experiência do aprender. As discussões realizadas apontam para a centralidade da mediação do professor, marcando o modo como a criança aprende e se apropria. Acredita-se que só será um processo significativo quando o professor conseguir despertar nessa criança a vontade de aprender. Aos professores cabe entender que o aluno só experimentará um processo de aprendizagem criativo e problematizador caso ele seja ativo em seu 
processo de aprendizado. Conforme apontado por Freitas (1998), cabe ao professor orientar e direcionar esse processo de participação.

\section{2}

\section{Pensando a relação da emoção e da aprendizagem a partir de Henri Wallon}

A importância de Henri Wallon (1968, 1971) é primordial no estudo da afetividade na relação com a aprendizagem. Wallon (1971) enfatiza a emoção presente em todas as ações do sujeito e sublinha a importância do meio em que a criança está inserida como um fator ligado diretamente ao seu desenvolvimento integral. Este ocorre em consequência da atuação do sistema nervoso sobre o sistema motor em conjunto com a experiência vivenciada pela criança.

Henri Wallon nasceu na França em 1879. Permaneceu na cidade de Paris onde faleceu em 1962, aos 83 anos. Sua biografia é extensa e multidisciplinar. Estudou Psicologia, Filosofia e Medicina e sempre esteve ligado à Educação. Lecionou Filosofia para o ensino secundário, discordando dos meios autoritários utilizados na época para se obter a disciplina. Voltou-se para as causas sociais e humanistas logo cedo. No final dos anos 1930, participou, nos movimentos contra o fascismo, de protestos contra a ditadura, na Espanha. Atuou intensamente na Resistência Francesa. Em 1931, Wallon integrou o Círculo da Rússia Nova, grupo formado por intelectuais que se reuniam com o objetivo de aprofundar o estudo do materialismo dialético e de examinar as possibilidades oferecidas por este referencial aos vários campos da ciência. A arte se fez presente na relação com a sensibilidade, “em sua teoria, que abre grande espaço para o campo estético, o da pura expressividade” (GALVÃO, 1995). Atuou como médico em instituições psiquiátricas tratando de crianças com deficiências neurológicas e problemas de comportamento. Esses conhecimentos tiveram grande efeito na sua teoria psicológica. No campo da Educação, entendia a relação da Psicologia com as práticas pedagógicas essenciais ao estudo da criança. À frente do Grupo Francês de Educação Nova de 1946 a 1962 e da Sociedade Francesa de Pedagogia nos anos seguintes, teve atuação importante no debate e na reflexão sobre as práticas do professor no seu campo e, sobretudo, ao entender “a criança como um ser ativo, concreto e ativo no seu meio” (GALVÃO, 1995). 
Como proposta desse estudo, atento ao desenvolvimento do sujeito em sua integralidade no mundo, Wallon (1971, p. 46) escreve sobre o aperfeiçoamento “dos mecanismos motores que o colocam em relação com o meio e sua atividade intelectual entre seus automatismos e sua ação intencional ou voluntária” nos modos subjetivos de existência.

A construção da subjetividade se relaciona com a dimensão afetiva, sendo entendida como o encontro da "construção da pessoa com o conhecimento" (WALLON, 1971, p. 46). A emoção mobiliza os sujeitos a conhecer, a aprender, a se relacionar com pessoas e objetos. Ou seja, as emoções estão ligadas à inteligência e dependem da interação social e da linguagem que se desenvolverão através dos grupos sociais. Para Galvão (1998), a emoção se expressa nas interações sociais que os indivíduos estabelecem em seu meio social. Segundo Wallon (1971), ela é o pilar do desenvolvimento humano, está ligada à sobrevivência do indivíduo.

Ainda para Wallon (1971), a afetividade e a inteligência seguem juntas desde o início da vida. Ao longo do crescimento, tomam caminhos diferentes, porém o atravessamento das duas ocorre para que atividades cognitivas, sociais e psíquicas se desenvolvam de maneira satisfatória.

A história da construção da pessoa será constituída por uma sucessão pendular de momentos dominantemente afetivos ou dominantemente cognitivos, não paralelos ou integrados. Cada novo momento terá incorporado as aquisições feitas no nível anterior, ou seja, na outra dimensão. Isso significa que a afetividade, depende, para evoluir, de conquistas realizadas no plano da inteligência, e viceversa (DANTAS, 1992).

No início da vida, a afetividade é descrita por Wallon (1971) como puramente emoção, dependente da troca entre os indivíduos. Essa possibilidade de intercambiar é baseada em afetos e na interação e na ação a partir de conteúdos que estão envolvidos nessa troca. As dimensões individual e social estão articuladas de forma complexa, atravessadas pela cultura. Assim como Vygotsky, Wallon (1971) descreve o indivíduo como ser social e afirma que seu desenvolvimento e crescimento enquanto sujeito depende da relação com o outro.

Na teoria walloniana, a afetividade tem uma abrangência maior que a emoção. Enquanto esta última é demonstrada por aspectos orgânicos muito específicos: alteração na respiração, nos batimentos cardíacos e na gesticulação “modificações visíveis do exterior, expressivas, que são responsáveis por seu 
caráter altamente contagioso e por seu poder mobilizador do meio humano" (GALVÃO, 1995, p. 61); a afetividade, ao longo do crescimento da criança, é expressa pela linguagem na ampliação da organização mental.

O recurso à fala e à representação mental faz com que variações nas disposições afetivas possam ser provocadas por situações abstratas e ideias ser expressas por palavras. É grande o destaque que a análise walloniana dá ao componente corporal das emoções. Wallon mostra que todas as emoções podem ser vinculadas à maneira como o tônus se forma, se conserva ou se consome (GALVÃO, 1995, p. 62).

O “ato motor” para Wallon (1971) está ligado às emoções e demonstra através dos movimentos da criança como estes estão sendo internalizados. Assim, a emoção está ligada à parte motora e tem sua expressividade no corpo através dos movimentos (WALLON, 1971; DANTAS, 1992). “O caráter altamente contagioso da emoção vem do fato de que ela é altamente visível, abre-se para o exterior através da mímica e da expressão facial” (DANTAS, 1992).

O corpo expressa em movimentos os pensamentos que estão em curso. As dificuldades na escola, por exemplo a leitura, podem causar uma mudança de posição. Um texto mais reflexivo causa mudanças nas expressões faciais, podendo facilitar um possível caminho em relação à criança que aprende. Galvão (1995) afirma que a criança reage às situações que acontecem ao seu redor através do corpo. Através de movimentos mais bruscos ou de expressões faciais, a criança demonstra como mantém relação com o exterior.

É como se a excitação provocada se espalhasse pelo corpo, imprimindo-lhe determinada forma e consistência e resultando numa impregnação perceptiva, por meio da qual a criança vai tomando consciência das realidades externas. É por meio desta impregnação perceptiva que a criança torna-se capaz de reproduzir determinada cena após tê-la presenciado, ou seja, de imitar. Para Wallon, a imitação é uma forma de atividade que revela, de maneira incontestável, as origens motoras do ato mental (GALVÃO, 1995, p. 72).

Ainda no contexto corporal, a imitação não vem a ser uma simples repetição de gestos e movimentos, mas, sim, ela ocorre por uma projeção do pensamento nos movimentos do corpo. Trata-se da extensão de uma ideia que a criança completa com gestos para conseguir expressar seu entendimento. Ao longo dos progressos que ela faz cognitivamente, haverá uma integração dos movimentos com a inteligência (GALVÃO, 1995). 
A independência da criança tenderá para movimentos mais organizados e menos impulsivos no decorrer do seu desenvolvimento. As influências culturais e sociais farão diferença nesse aprendizado motor de maneira que a expressividade continue a aparecer mesmo com o seu amadurecimento.

Em relação às contribuições de Wallon para a escola, enfatiza-se sua concepção dialética sobre o desenvolvimento infantil, tema tão importante para a formação dos educadores. Suas reflexões sobre emoção, movimento, formação da personalidade, linguagem e pensamento podem trazer importantes subsídios para a prática pedagógica. $\mathrm{O}$ autor também destaca a relação entre Pedagogia e Psicologia, como áreas que trazem implicações mútuas, uma ligação que se expressa na “investigação e observação”. De acordo com Galvão (1995), Wallon traz críticas extremamente atuais, indicando uma necessidade de superação do dilema entre o autoritarismo do modelo tradicional e a espontaneidade das práticas que têm a pretensão de serem progressistas. Também chama a atenção para a insuficiência das discussões pedagógicas sobre a relação professor-aluno, sendo urgente aprofundar as reflexões sobre o papel da escola na sociedade.

A pedagogia se relaciona com a cultura, devendo buscar mudanças de tempos em tempos. Dentro dos aparatos escolares e nas relações que acontecem neste contexto de interação social, entre os diversos atuantes, são oferecidos conceitos pragmáticos acrescidos de conteúdos de afetividade que terão efeito na subjetividade de cada um. A sala de aula é, portanto, um “coletivo em função das necessidades das crianças”. Contudo, deve-se considerar o papel da disciplina na construção da autonomia e do autodomínio, indispensável para o crescimento individual (ALMEIDA, 2011).

Uma contribuição de Wallon para a educação é o projeto LangevinWallon $^{1}$, desenvolvido numa escola francesa e resultado de um trabalho realizado entre 1945 e 1947, por uma comissão comprometida com mudanças no ensino e na sociedade, uma resistência à seletividade do sistema. Nesse projeto, Paulo Langevin era o presidente da comissão e, após sua morte, Wallon assumiu seu lugar com o objetivo de reorganizar o ensino baseado nos princípios de justiça

\footnotetext{
${ }^{1}$ Esse projeto teve real importância na reforma do Ensino Francês, e culminou em mudanças pedagógicas importantes no ensino secundário, donde se ressalta atuação e o reconhecimento da figura do professor; a atenção às dificuldades e capacidades dos alunos em sala de aula; o trabalho em equipe; não se abstendo das questões individuais de cada um no nomeio escolar, trazendo, portanto, relevância para as reflexões deste estudo.
} 
social e de conhecimentos científicos sobre o desenvolvimento humano (GALVÃO, 1995). A ênfase dada pelos idealizadores era no aluno e no professor como peças chaves para o desenvolvimento de ambos nos aspectos subjetivo e social, entendendo que a organização do trabalho deve contemplar as singularidades, propondo atividades individuais e coletivas.

O projeto Langevin-Wallon sugere sobre métodos de ensino, considerando que esses devem se adequar às capacidades dos alunos e ao conteúdo de cada disciplina e garantir a atividade dos alunos. Nesse sentido, devem ser alternados o trabalho individual e o trabalho em equipe; exigindo-se no trabalho individual que cada um enfrente as dificuldades com os seus recursos e limites próprios, e no trabalho em equipe, que, ao mesmo tempo em que se revelem as capacidades intelectuais, sejam reveladas as sociais, no desenvolvimento da responsabilidade perante a obra coletiva (ALMEIDA, 2011).

Wallon (1971) sugere que para cada momento da infância sejam oferecidos "procedimentos pedagógicos" diferentes, pois os modos de se expressar não são os mesmos de acordo com a idade (WALLON, 1971). Nas palavras de Almeida (2011) a teoria de Wallon tem uma abordagem "humanista", com ênfase, em suas discussões, na importância da integração escola-aluno e o olhar para seu desenvolvimento nas suas demandas sociais. Por isso, é tão importante o professor ter olhar atento e sensível para as demandas dos alunos.

Ao analisar a relação que o professor deve ter com seus alunos, Almeida (2011) afirma, com base na teoria walloniana, que o professor deve "respeitar" e “observar” o aluno que está na sala de aula. A partir dessas duas ações, poderá desenvolver um trabalho mais satisfatório, apoiando o desenvolvimento a partir de um olhar equilibrado e sensível. Conhecer o aluno através de seus limites e potencialidades, como ele se expressa, como ele interage com os outros, como é o contexto de sua vida, é um caminho interessante para apoiar o processo de aprendizagem de cada criança. Dentro da perspectiva aqui analisada, a emoção deve ser sentida e exteriorizada pelos próprios alunos, e o professor deve estar em equilíbrio com as suas emoções para poder manter o ambiente em harmonia e oferecer caminhos para aqueles que ainda não conseguem se expressar.

Muitas das dificuldades de aprendizagem são decorrentes da falta ou deficiência do investimento da pessoa no ato de aprender. O professor observará a criança e a si próprio, para esclarecer os porquês do não envolvimento, e dará a ela o tempo para pensar, para se organizar, para elaborar seu trabalho e ter sucesso. A aprendizagem ocorre se está adequada aos interesses do aluno, e todo interesse nasce de uma necessidade (ALMEIDA, 2011, p. 84). 
A escola é o espaço onde a criança está boa parte do seu tempo, portanto, pode colaborar com o desenvolvimento do aluno. O contato com diferentes culturas e os diferentes modos de expressão fazem da escola um importante local de humanização. Almeida (2011, p. 85) ressalta que é “dever da escola oferecer às crianças, sem discriminação, o que há de melhor na cultura”. Essa experiência refletirá no indivíduo adulto e na sua interação e formação como agente social.

A escola deve ser facilitadora para a expressão de sentimentos, um espaço onde ocorram reflexões que atravessam a sala de aula e se refletem na vida fora do ambiente escolar. Assim, funcionará como meio privilegiado para o aprendizado, tendo o professor a função de mediador do conhecimento e da cultura (ALMEIDA, 2011), conciliando os interesses e as curiosidades dos alunos, assim como o conhecimento partilhado socialmente. Assim, entende-se que as dimensões humanas, a arte e a ciência devem ser tratadas de forma integrada.

\begin{abstract}
Visando a autoconstrução do sujeito, a escola deve acompanhar esse duplo movimento, o que implica oferecer oportunidades de aquisição e de expressão, nas quais se alterne a predominância das dimensões objetiva e subjetiva. Em termos curriculares, essa busca se reflete na integração entre a arte e a ciência (GALVÃO, 1995).
\end{abstract}

Os estudos do Wallon chamam a atenção para a importância das relações sociais no processo de constituição subjetiva, tendo o professor um lugar de destaque na formação dos alunos.

"É bom lembrar que a escola, ao possibilitar uma vivência social diferente do grupo familiar, desempenha um importante papel na formação da personalidade da criança” (GALVÃO, 1995, p. 101).

O posicionamento do professor marca as experiências educativas dos seus alunos, indo além dos muros da escola, refletindo na sociedade. Wallon (1971) pensa o desenvolvimento humano de forma articulada com a cultura, com a política. Por isso, o planejamento pedagógico deve contemplar uma diversidade temática que dialogue com o cotidiano dos alunos, facilitando diferentes formas de expressão. Assim, a escola tem como tarefa fortalecer os alunos como sujeitos reflexivos e críticos.

Essa compreensão da função da escola está diretamente relacionada as concepções de sociedade, de educação e de criança compartilhadas pela instituição. Ou seja, existem diferentes entendimentos de infância e do que as 
crianças são e devem ser presentes nas escolas e no trabalho educativo. Diante disso, este trabalho traz uma noção de infância como construção social marcada pela história. Ainda é importante destacar que a infância tem sido objeto dos discursos de especialistas da psicologia, normatizando e normalizando esse momento da vida. O próximo capítulo se dedicará ao tema da infância e da produção de subjetividade na contemporaneidade, e sua articulação com a escola. 


\section{A Infância e a Contemporaneidade: Modos de Subjetividade}

Para tratar do tema da infância na contemporaneidade, é preciso remontar os seus sentidos históricos, analisando as diferentes representações forjadas no movimento da história. Diante disso, parte-se de uma compreensão da infância como construção social. De acordo com Castro (1998, p. 16):

“(...) emprestar um sentido de construção histórica à infância implica analisar
como as práticas socioculturais (sejam elas os discursos, as ações e as
instituições) possibilitam, circunscrevem e determinam certos tipos de
experiência durante a infância”.

Contextualizar a infância nos seus modos subjetivos é essencial para que se fale da diversidade dos modos de existir enquanto criança. Por um lado, a infância acontece e se constrói dentro dos muros escolares, esses que exigem um enquadramento de um perfil como aluno. Por outro, percebe-se modos de infância frente a uma aparelhagem tecnológica que deixam a criança de alguma forma paralisada diante de tantos estímulos e informações; a subjetividade também é construída em conjunto com os modos de existir e coexistir das famílias. Em busca do equilíbrio de estar afetivamente com suas crianças e de não perder tempo em marcar lugar no mercado de trabalho, é primordial entender os modos subjetivos que a infância ocupa na contemporaneidade no contato com responsáveis nem sempre presentes. (CASTRO, 1998).

A infância só veio a aparecer na sua forma sensível e ingênua no século $\mathrm{XX}$. Antes desse período, a criança era vista como um adulto menor: usava roupas de adultos em tamanhos pequenos e a ideia era que fossem obedientes sem muito espaço para vontades ou expressão de sentimentos e emoções (LIGHTFOOT \& VALSINER, 1992). No período medieval, tudo era permitido na presença das crianças: uso da linguagem, hoje considerada vulgar e inadequada; não havia a ideia de espaço privado, um local onde as crianças ficassem protegidas e sob cuidado da família da forma que temos hoje. É possível falar de um "não-lugar” da infância, sem o reconhecimento de suas especificidades. Para Ariès (1981), a civilização medieval não percebia uma fase transitória entre a infância e a idade 
adulta. Nesse período, era alta a taxa de mortalidade infantil, as preocupações limitavam-se às questões de saúde.

De acordo com Lightfoot e Valsiner (1992), todos os impulsos deveriam ser suprimidos em prol de uma grande obediência e rigidez, a mesma que era utilizada com os adultos. Na educação, era indicado que os jovens seguissem a tradição da época e fossem direcionados para não seguir caminhos obscuros, como ceder a desejos e tentações (LIGHTFOOT \& VALSINER, 1992). A partir de mudanças sociais e históricas, a criança passa a ser olhada em suas singularidades, sendo reconhecido o contexto infantil, com o lado travesso e as vontades do mundo infantil. Com isso, a infância ganha notoriedade no mundo dos adultos.

Transformações históricas e morais que desembocaram, através da sensibilidade burguesa, na construção do sentimento de infância. Dessa forma, a separação entre adultos e crianças na experiência social concreta refletiu-se na representação moderna da infância - crianças passam um tempo sob o olhar dos educadores e pedagogos, considerando suas capacidades intelectuais distintas dos adultos.

Esses diferentes entendimentos da infância e do que as crianças são e devem ser tencionam as relações sociais contemporâneas, marcando o trabalho da escola. Arroyo (2008) cita a importância do aprofundamento da Pedagogia para a diversidade de experiência das infâncias e diz: “As escolas tendem a interpretar as diversidades apenas como diferenças de ritmos nos processos de aprender saberes e condutas”. As políticas escolares tendem a trabalhar com um perfil único de criança, ocasionando assim agrupamentos e classificações a partir de um conceito único de infância e adolescência.

Uma perspectiva da Psicologia do Desenvolvimento tem, ainda hoje, grande participação na criação de uma padronização, normatização, da infância. Dentro dessa perspectiva, o curso da vida humana é visto de forma previsível e sequencial. Contudo Castro (1998, p. 21) critica essa visão de que a infância e a adolescência possam ser analisadas de forma sistematizada, sem se levar em conta fatores não biológicos. Tais fases, segundo aquela corrente, foram tomadas como etapas do desenvolvimento, e a idade adulta como estagnação ou ponto de chegada. A inspiração darwiniana é que teria estimulado o estudo da infância no intuito de descobrir, neste estágio do desenvolvimento, as origens das 
características adultas, tomando a criança apenas como organismo biológico, abstraída do seu contexto material e social. Mas dessa forma, a compreensão do sujeito na integralidade se tornaria cada vez mais distante.

As instituições sociais, com destaque a escola, têm operado com a ideia de infância como débito cultural e social, que precisa da socialização para ser um adulto. Assim, a infância é entendida como um traço a ser extinto; a criança é um menor, incapaz, aprendiz, que precisa ser tutelada pela família e pelo Estado. A Psicologia, com a sua norma, descreve o caminho adequado para o desenvolvimento, com uma noção universal de infância que serve para todas as histórias, culturas e épocas, atravessado por um caráter moral, falseado pelo discurso científico (CASTRO, 1998).

Críticas a essa lógica desenvolvimentista reforçam a concepção da criança como sujeito histórico e social, que produz cultura e nela é produzida, constituída a partir de uma classe social, etnia, gênero e por diferenças físicas, psicológicas e culturais. Também apontam a importância de se estudar a infância por si própria, rompendo com o adultocentrismo, entendendo a criança como um ser social e histórico, produtora de cultura. O paradigma da competência infantil chama a atenção para a interdependência de adultos e crianças, onde ambos são capazes de produção e reprodução da vida e da cultura. As crianças participam coletivamente na sociedade e são dela sujeitos ativos. O conceito de ação, como capacidade de intervenção no mundo, iguala crianças e adultos. Assim, as crianças têm muito a ensinar aos adultos no processo de aprendizagem, trazendo à tona sua visão de mundo (CASTRO, 1998).

Arroyo (2008) traz um importante ponto de reflexão para a Pedagogia quando aponta a diversidade dos alunos e das escolas e propõe formas de lidar com a pluralidade. Hoje sabemos que não existe uma infância só ou uma infância que passa pelos mesmos processos de desenvolvimento, em função apenas da faixa etária. Existem várias formas de infâncias e estas são direcionadas com o contexto e com a forma que cada criança o vivencia.

Nem sempre são evidentes essas concepções contraditórias que subsidiam as relações e as práticas escolares. Arroyo (2008) incita a reflexão sobre essas compreensões que marcam a experiência de ser adulto através das próprias memórias da infância, bem como práticas no cotidiano da escola que desconsideram a potência infantil. Muitas vezes educadores marcados por uma 
infância não muita ativa, em que não tinham voz, insistem em certas classificações que não cabem no mundo de hoje.

A escola, como um dispositivo disciplinador e normatizador, tem uma forte influência nos processos de subjetivação, com a padronização de modos, formas e processos que buscam definir um perfil ideal de criança, de aluno. Castro (2013) traz a reflexão sobre essa universalidade e os caminhos que apontam para a vida do aluno, que se torna algo em prol de um coletivo ou o que se espera dela. $\mathrm{O}$ estudar por si só fica em um plano distante, já que se espera que ele estude para ter uma boa colocação no mercado de trabalho, todo incentivo gira em torno de uma boa colocação profissional. O sentido se perde nesse caminho, onde há muitos pais e professores que exigem desse aluno um desempenho escolar determinado externamente, sem levar em conta os desejos e as histórias dos sujeitos.

A subjetivação da criança está ligada também ao olhar sobre as diferenças de cada um, ou seja, de como a alteridade (estado ou qualidade do que é do outro, distinto, diferente) nos é constitutiva. A subjetividade da criança vai sendo construída nas suas ações que são também uma forma de reelaboração e recriação do que está ao seu redor.

A diversidade das experiências infantis, pertencentes a diferentes classes e etnias, apontam para várias formas de viver, e ratificam que não existe um modelo único e adequado de aluno, cabendo aos educadores a valorização da diversidade, a inclusão de todos nas práticas educacionais, comprometidos com uma aprendizagem significativa (DAYRELL, 1996). Também é tarefa do professor valorizar as culturas das famílias, principalmente quando falamos das famílias de classes populares nas escolas públicas. É preciso estar atento aos diferentes contextos apresentados e encontrar uma melhor maneira de ajudar a criança a construir um sentimento de pertencimento na escola.

É preciso repensar as discussões do campo da pedagogia e da psicologia que têm alimentando o trabalho pedagógico, sendo necessária uma mudança de olhar para a criança, sobre seu desenvolvimento infantil, ampliando o diálogo com as diferentes dimensões humanas - arte, ciência e vida. Nesse sentido, a ampliação das questões relativas à infância, no contexto atual, pode romper a distância entre os discursos científicos e a prática (ARROYO, 2008). Não se pode enquadrar a criança em um modelo dito ideal. 
Outra questão que tem desafiado a escola é o consumo na infância, trazendo implicações éticas na constituição subjetiva das crianças. A cultura do consumo tem alterado as interações e o modo como se constitui a experiência infantil. A relação de autoridade dos adultos em relação às crianças parece estar fragilizada - "Se antes o adulto (...) inspirava respeito e era temido pela criança, hoje o quadro se inverte” (SOUZA, 2005). A ausência dos pais de classe média levam ao estabelecimento de uma relação desconcertante.

(...) transformados por nós, sem qualquer piedade ou indignação, em mercadoria de uma época, a criança contemporânea tem como destino flutuar erraticamente entre adultos que não sabem mais o que fazer com ela. As crianças passam assim a compartilhar entre si suas experiências mais frequentes, as quais se limitam, na maioria das vezes, ao contato com outro televisivo, remoto, virtual e maquínico (SOUZA, 2005).

Observa-se, nas classes médias, relações que buscam atender as demandas das crianças a qualquer custo, especialmente para consumir. Por outro lado, crianças de classes populares assumem responsabilidades muito além de suas possibilidades. Em todos os contextos, as crianças são expostas à publicidade infantil, à exploração e à violência. O consumo tem afetado todas as instâncias da vida social e da cultura contemporânea, trazendo a marca do individualismo e da mercantilização das relações (KRAMER, 2011). De acordo com Kramer (2011), a contemporaneidade traz um acirramento da perda da capacidade de diálogo porque as pessoas conversam sobre os preços das coisas, mas não possuem a capacidade de narrarem suas experiências.

A relação do consumo atual é marcada pelo desejo desenfreado de acumular cada vez mais, mesmo sem pensar na função desses objetos. A mídia intensifica esse processo, mostrando o que é supostamente melhor, produzindo a crença que o valor do indivíduo está nos objetos de consumo. São "vendidas" imagens e significados também. O consumo vem produzindo o desejo das crianças, desde muito cedo é destinado a elas um enorme número de objetos de consumo, comercializados com a ideia de essenciais para a vida das famílias. Souza (2005) também aponta para a centralidade do consumo dos objetos tecnológicos, que roubam espaço de encontros familiares. Essa situação tem sido realçada pelos pais ausentes, com suas rotinas intensas de trabalho, que tem usado a lógica do consumismo como forma de suavização da culpa. Sobre o mercado infantil, a autora (2005) comenta: “A indústria de consumo se dirige diretamente à 
criança e pretende seduzi-la com "novos" objetos e signos fabricados especialmente para ela”.

Esse consumo desenfreado tem sido responsável pelo adoecimento de crianças, quanto mais se tem, mais se deseja ter o objeto mais novo que foi lançado no mercado (SOUZA, 2005).

Contextualizando as novas configurações familiares e retornando em uma época que existia uma lógica de respeito vinculado ao medo das crianças pelos pais, hoje existe quase uma lógica inversa. A criança passa a ser o centro das atenções, o “não” está cada vez mais raro e o "ter” virou uma maneira de mostrar que "sou melhor do que o outro". Nesse sentido, a obsessão pelo consumo, em substituição ao afeto, é um dos fatores principais que caracterizam os valores distorcidos da infância atual.

Os brinquedos e a tecnologia vêm para tomar conta da infância onde os pais corroboram com uma questão contemporânea nas famílias, reforçando o consumo infantil. A autora ressalta que a tecnologia está muito presente em ambientes familiares e que atravessa, algumas vezes, as relações de um modo geral. É alarmante a proporção que a necessidade de comprar vem alcançando, como forma de status e ao mesmo tempo caminhando paralelamente com o crescente números de crianças ansiosas que usam medicamentos para curar transtornos. Novos sintomas surgem desenfreadamente. Quanto mais se tem, mais se deseja ter o apetrecho mais novo do mercado (SOUZA, 2005).

Eis um paradoxo: os pais que atuam fortemente no mercado de trabalho querem alcançar o sucesso profissional, porém, de certa forma, sentem-se culpados por não estarem frequentemente com seus filhos. A lógica do consumismo exacerbado aparece para apaziguar essa culpa.

A relação do consumo atual é marcada pelo significado que se dá quando se tem mais. A mídia intensifica esse processo, mostrando o que é o melhor e no que fará melhor a pessoa que comprar aquele objeto. Com isso, indiretamente reforça que as crianças dessa geração têm um mercado voltado só para elas e esse mercado cresce a cada dia. Como proposto por Souza (2005):

O mercado não somente soube atrair o olhar da criança como passou a dirigir diretamente a ela e não mais aos seus pais. A indústria de consumo se dirige diretamente à criança e pretende seduzi-la com "novos" objeto e signos fabricados especialmente para ela (SOUZA, 2005). 
O reconhecimento do papel social das crianças tem produzido uma inversão, fazendo com que adultos abdiquem do seu lugar de autoridade. A escola precisa valorizar e reconhecer a criança sem abandoná-la. Quando professores abrem mão do seu lugar na educação, da sua autoria, dão espaço para o confronte e o descaso, se distanciando de uma relação pautada no respeito e no diálogo. É preciso assumir a assimetria entre adultos e crianças, ou seja, o professor tem responsabilidades com seus alunos. Isto não significa uma defesa de práticas autoritárias, mas a afirmação de uma horizontalidade ética entre professores e alunos, ambos como integrantes essenciais do processo educativo. 


\section{A Escola: Modos de Funcionamento}

Este capítulo tem como objetivo refletir sobre os modos de funcionamento da escola. A experiência dos que estão em sala de aula é colocada em cheque, quando alunos e professores precisam ter um encontro com o conhecimento. Buscar uma forma para que esse conhecimento atenda às necessidades subjetivas é uma questão da atualidade. Após analisar os diferentes sentidos conferidos à infância ao longo da história e as especificidades dessa experiência geracional na contemporaneidade, é importante olhar para a escola de forma contextualizada, como responsável por produzir modos de funcionamento que trazem enquadramentos para os sujeitos.

A escola é formada por vários caminhos, disciplinas, hierarquias e pelas relações que estão inseridas no contexto escolar. As relações tornam-se múltiplas dentro da diversidade dos que transitam na escola e, especificamente, entre os alunos que a compõem. Refletindo sobre essa instituição, Dayrell (1996, p. 139) cita:

"A escola é vista como uma instituição única, com os mesmos sentidos e objetivos, tendo como função garantir a todos o acesso ao conjunto de conhecimentos socialmente acumulados pela sociedade.”

Historicamente, a escola tem reunido pessoas com objetivo de ensinar, supostamente interessadas no conhecimento, produzindo hierarquias, e diferenciações entre os grupos sociais.

Depois, no entendimento de que o acesso ao conhecimento também criava acesso a bens materiais e fazia a ascensão social, foi se consolidando como um espaço gerador de privilégios, pois ter acesso ao conhecimento também poderia gerar diferentes oportunidades sociais (TACCA \& GONZÁLEZ REY, 2008).

Para Tacca e González Rey (2008), a escola, comprometida com a democracia e com a construção de uma educação para todos, teve a pretensão de trazer o conhecimento de uma forma única, na tentativa de que todos entendam. No entanto, se instaurou como um espaço totalizante e normatizador, com a tarefa de atender a muitos de uma maneira uniforme, mas sem levar em conta que é frequentada por uma diversidade inimaginável de alunos. 
Dayrell (1996) analisa o conceito de escola como um espaço sociocultural, ampliando essa discussão através da valorização da diversidade de subjetividades e do contexto cultural, entendendo que estes interferem na função e no trabalho escolar. Entende-se que a escola é um espaço de pessoas, modos de vida e formas de pensar diferentes, em que todas essas diferenças irão convergir em sala de aula. Porém, as instituições escolares têm apresentado um forte viés baseado na padronização, na formalização e na hierarquização, o que produz formas rígidas de se relacionar com o conhecimento. Tacca e González Rey (2008) afirmam que “a confiança de que esse é o modelo necessário carrega a ideia de que todos são iguais e devem aprender as mesmas coisas, ao mesmo tempo e da mesma forma”. Essa realidade requer um pensamento crítico mais aprofundado sobre o aluno e o trabalho na sala de aula.

A partir da década de 1980, tem-se um olhar mais aprofundado para o aluno e para a escola (DAYRELL, 1996). Houve uma quebra no paradigma do significado da escola como instituição única, que serve para todas as culturas, épocas, histórias, incorporando uma concepção de aluno como sujeito, aquele que age e opina na sociedade em que vive e que passa parte significativa do seu tempo no ambiente escolar. Esse sujeito transforma o mundo através da sua ação, interfere no sentido e na função da escola.

Transforma-se o papel da instituição escolar de um lugar baseado, exclusivamente, em um conjunto de regras que visam regulamentar as vidas dos sujeitos na escola, em uma tentativa de homogeneização, em um espaço tensionado por movimentos de resistência que ocorrem através de “alianças", “conflitos” e “transgressões” (DAYRELL, 1996). Estes dão sentido para as relações estabelecidas na escola, influenciando os processos de socialização e produção de subjetividades, interferindo nos papéis sociais e na função da escola. Assim, observa-se um movimento complexo de produção de sentidos, não linear, marcado pelo conflito, pela disputa entre a estrutura da escola disciplinar e autoritária e pela diversidade das experiências dos sujeitos.

Castro (2013) ressalta a importância da escola para os agentes que nela estão inseridos. Alunos e professores dão sentido a suas histórias como seres sociais através de suas experiências escolares. O significado que será dado à escola pode tornar uma experiência proveitosa e positiva ou negativa na vida das crianças. As relações de significados estabelecidas na escola se misturam com 
experiências contemporâneas na infância. O advento das mídias digitais computador e TV, trouxeram mudanças na lógica ensino-aprendizagem, inclusive na velocidade com que as crianças e jovens têm acesso a informações que podem ser averiguadas e levadas para a escola. As novas formas de se informar e aprender exigem mais do professor em sala de aula, já que ele precisa estar sempre atento e preparado para acompanhar essa dinâmica até então inédita.

Dentro desse cenário complexo, a escola tem como tarefa o ensino e a aprendizagem. O aprender está em tudo que rodeia o ser humano, nos modos de existir, nos processos de socialização, e está presente na escola, nos diversos modos de habitar este contexto (TACCA \& GONZÁLEZ REY, 2008). Muitas vezes, a escola apresenta um cotidiano enfadonho, pouco interessante, distante da vida. Dentro dessa perspectiva, a experiência do aprender se sustenta em teorias baseadas na acumulação de informações (de pequenos elementos que se desenvolvem de forma sequencial e hierárquica) e na associação de estímuloresposta (baseada no reforço positivo, na motivação externa). Essa compreensão é um dos fundamentos do pensamento dos psicólogos behavioristas, ainda com certa influência nos currículos e nas práticas de avaliação e de ensino (CASTRO E SOUZA, 2017).

A transmissão e repetição mecânica não levam em consideração as potencialidades dos alunos na produção de sentidos. Torna-se um aprendizado sem trocas, sem ampliação dos saberes. O processo de aprendizado fica reduzido a perseguir as melhores notas e a aprovação. A avaliação é tomada como uma medida, numa perspectiva unicamente técnica, que, por meio de rigor e neutralidade, teria o objetivo de medir as aprendizagens dos alunos. É possível identificar a influência dos testes de inteligência e aptidão para a construção dessa noção de avaliação.

Dentro dessa reflexão, Dayrell (1996) defende que o conhecimento deve ser transformado pelo sujeito que o recebe. Na direção dessa crítica, Freire (1987) colabora ao questionar o modelo da “educação bancária”, no qual os educandos são tomados como passivos, dóceis, e os conhecimentos, como estáticos, compartimentados, menosprezando as experiências dos sujeitos - “os transforma em 'vasilhas', em recipientes a serem 'enchidos' pelo educador” (FREIRE, 1987, p.33). A lógica da educação bancária parece ser bastante significativa nos espaços escolares, como é possível perceber através do aumento 
de avaliações que têm a finalidade de medir as aprendizagens dos alunos. Esse modelo traz uma prática monológica, baseada numa tagarelice do professor, na narração de conteúdos que devem ser assimilados, de forma mecânica, acrítica, pelos educandos.

Dessa forma, essa educação tem como objetivos a fixação, a adaptação ao mundo, a memorização mecânica, a repetição sem compromisso com significados, o que torna os sujeitos docilizados, domesticados pelo depósito dos conhecimentos transmitidos. Essa educação traz o homem em abstrato, isolado, desconectado do mundo.

Educador e educando se arquivam na medida em que, nesta destorcida visão da educação, não há criatividade, não há transformação, não há saber. Só existe saber na invenção, na reinvenção, na busca inquieta, impaciente, permanente, que os homens fazem no mundo, com o mundo e com os outros (FREIRE, 1987, p. 33).

Contudo, os homens possuem a vocação de humanizar-se, sendo levados a questionar e resistir às contradições da educação bancária, na busca pela libertação, por uma prática problematizadora e criativa.

Castro (2013) ressalta a falta de vinculação ao aprendizado que separa alunos e professores. A falta de sentido no aprendizado por parte dos alunos diz sobre a falta da abertura ao diálogo em sala de aula.

Somente com a possibilidade de reinventar o poder de transformação da fala de ambos, em outras palavras, fazer com que um e outro sejam afetados pelo que cada um tem a dizer, a educação pode, de fato, acontecer (CASTRO, 2013).

Além da falta de diálogo, de abertura ao outro, da impossibilidade de aprender com esse encontro intergeracional, a escola é marcada por conteúdos iguais e aulas sendo ministradas por professores cansados que não conseguem demonstrar envolvimento e compromisso com as aulas, agravados pela falta de condições de trabalho. A qualidade das interações observadas, muitas vezes, é insatisfatória, marcada por adjetivos como "bom”, “mau”, “preguiçoso”, e pela diferenciação dos alunos a partir das notas. Eles ficam marcados pelo resultado, e não pelo processo de aprendizagem (DAYRELL, 1996).

É um diálogo com estereótipos socialmente criados, que terminam por cristalizar modelos de comportamento, com os quais os alunos passam a se identificar, com maior ou menor proximidade: o "bom aluno"; o "mau aluno", o "doidão"; o "bagunceiro"; o "tímido", o "esforçado" (DAYRELL,1996, p. 153). 
Mesmo nos dias de hoje, a escola continua com ares convencionais, esperando um bom desempenho no processo escolar através da multiplicação de avaliações, como se houvesse uma simetria entre aprender e fazer prova, uma educação fria e sem a presença da voz dos alunos. Sobre essa orientação normativa conservadora, Castro (2013) fala sobre os lugares do aluno e do professor:

Neste sentido, acredita-se que o papel do aluno se delimita pelas convenções do lugar de sujeito aprendiz e receptor do que lhe oferece o adulto. Por outro lado, o papel da professora é considerado como o do adulto que sabe, e por isso deve ser escutado e respeitado. Atendendo-se a esta perspectiva, torna-se difícil questionar e subverter a ordem vigente (CASTRO, 2013).

O processo de aprendizado pode se tornar apático e sem voz, caso não se tenha um professor atento a escutar as necessidades desses alunos. Castro (2013) ressalta que uma opinião para ser fortalecida necessita ser ouvida e considerada. Opiniões construídas no vácuo vão transformando a escola em um vazio, distanciando mais os integrantes da escola. Nesse contexto, o saber vem como obrigatoriedade, tornando resistente $\mathrm{o}$ aprender e o acesso às trocas de conhecimento e não abrindo caminhos para a expressividade (CASTRO, 2013).

A educação, para Freire (1987), deve ser um processo de humanização, de orientação e do pensar crítico constante, trazendo diálogos para proporcionar expressões autênticas dos alunos. Cabe dizer que a lógica do poder constitui a escola, portanto, esse poder pode ter uma lógica diferente de uma hierarquização rígida, e sim de trocas de saberes, do professor e alunos, buscando uma horizontalidade ética (CASTRO, 2013; FREIRE, 1987).

A diversidade dos alunos deve ser valorizada dentro do processo do aprendizado, tendo como eixo do trabalho escolar a pluralidade e a democracia. A escola tem um papel fundamental nesse processo, como palco das relações e na construção de uma sociedade mais humanizada. É preciso resgatar a dimensão política da escola, refletindo sobre os diferentes sentidos em disputa.

Sobre o significado da escola, as respostas são variadas: o lugar de encontrar e conviver com os amigos; o lugar onde se aprende a ser "educado"; o lugar onde se aumenta os conhecimentos; o lugar onde se tira diploma e que possibilita passar em concursos. Diferentes significados, para um mesmo território, certamente irão influir no comportamento dos alunos, no cotidiano escolar, bem como nas relações que vão privilegiar (DAYRELL,1996, p. 144). 
Muitas vezes, os sentidos estão expressos na própria organização escolar, como os muros altos, grades, paredes cinzas que não trazem a possibilidade de os estudantes se identificarem com a escola. Os espaços não “chamam” para uma interação maior, e os corredores levam sempre às salas de aula (DAYRELL, 1996). Assim, a socialização é um processo de formação de grupos, de identificações, e também de “afastamentos” dos indivíduos. Espaços coletivos, como os corredores, pátios e o caminho para a escola se tornam parte desse processo de socialização.

(...) podemos afirmar que a sociabilidade, para os jovens, parece responder às suas necessidades de comunicação, de solidariedade, de democracia, de autonomia, de trocas afetivas e, principalmente, de identidade (DAYRELL, 2007).

Partindo da compreensão de que o espaço pode ser educador e facilitar as mediações, seria interessante que os alunos pudessem interferir no ambiente, realizar “arranjos” para se sentirem mais à vontade, promovendo os encontros, a possibilidade de montar grupinhos nos corredores para conversar. Muitos comportamentos tomados como indisciplinados, quando os alunos transgredirem e rabiscarem as carteiras e as paredes da escola, quando procurarem lugares para namorar, estas atitudes podem significar uma forma de resistência a uma organização espacial que não leva em consideração suas demandas. Os professores também dão novos significados para o ambiente escolar quando buscam aulas ao ar livre na tentativa de oferecer o contato com a natureza. Nesse movimento, a escola torna-se um ambiente repleto de significados, construídos pelos alunos e professores de forma autoral.

As cenas descritas evidenciam que a escola é essencialmente um espaço coletivo, de relações grupais. O pátio, os corredores, a sala de aula materializa a convivência rotineira de pessoas. No momento em que os jovens cruzam o portão gradeado, ocorre um "rito de passagem", pois eles passam a assumir um papel específico, diferente daquele desempenhado em casa, tanto quanto no trabalho, ou mesmo no bairro, entre amigos. Neste sentido, os comportamentos dos sujeitos, no cotidiano escolar, são informados por concepções geradas pelo diálogo entre suas experiências, sua cultura, as demandas individuais e as expectativas com a tradição ou a cultura da escola (DAYRELL, 1996, p. 148).

Dayrell (2007) aponta desafios da contemporaneidade como as transgressões, rebeldias, atos violentos, injustiças sociais que acontecem no cotidiano escolar, que geram "uma descrença política e um esgarçamento dos 
laços de solidariedade” (p. 1.111), mas que precisam ser transformados em temas de reflexão da escola. Tomar esses elementos como objetos de problematização não significa dar a importância a regras. Sua estruturação tem função subjetiva essencial para a educação dos alunos, contudo, isso não deve ser feito de forma autoritária, mas sim coletiva.

Outro desafio é a rigidez das propostas pedagógicas. A tensão entre professor e aluno é expressa na relação com os conhecimentos e os processos de aprendizagem. Atividades muito estruturadas podem ocupar um lugar autoritário, impondo sobre a escolarização conteúdos fixos, o que se espera transmitir sem nenhuma interferência dos alunos. Distanciado da realidade, o currículo cria uma relação artificial com o conhecimento, já que não existe articulação com a vida cotidiana dos estudantes. Assim, sem a produção de sentidos e o envolvimento dos alunos, não se tem a condição essencial para a aprendizagem, além da impossibilidade de os estudantes demonstrarem sua criatividade com espontaneidade e estabelecerem interações com seus pares (DAYRELL,2007; TACCA \& GONZÁLEZ REY, 2008).

A escola tem assumido, historicamente, uma função disciplinadora, impedindo a livre expressão e não valorizando as diferentes culturas. Os tempos e os espaços são controlados pelos adultos, que são vigilantes das relações entre os estudantes, controlam os diálogos, as brincadeiras, os corpos. Nem o recreio parece permitir a liberdade dos alunos (DAYRELL, 1996). Mesmo com estes limites, com as poucas oportunidades para a troca, os estudantes resistem no cotidiano da escola, criando brechas para o encontro, para a expressão. Assim, a cultura dos alunos estará permeando o ambiente escolar, e, dessa forma, promovendo a interação da escola com as diversas culturas, e proporcionando uma abertura à sua expressividade (DAYRELL, 2007).

Olhar a instituição escolar pelo prisma do cotidiano permite vislumbrar a dimensão educativa presente no conjunto das relações sociais que ocorrem no seu interior. A questão que se coloca é que essa dimensão ocorre predominantemente pela prática usual dos alunos, à revelia da escola, que não a potencializa. Os tempos que a escola reserva para atividades de socialização são mínimos, quando não reprimidos (DAYRELL, 1996, p. 151).

Os debates que vêm ocorrendo sobre a relação aluno-escola trazem um contexto “apocalíptico”, responsabilizando o aluno ou a família ou o professor sobre o fracasso escolar (DAYRELL, 2007). A escola atribui aos alunos seu 
desinteresse no processo de aprender, não visitando os seus processos pedagógicos. Para os alunos, a escola se torna a obrigação diária e cada vez mais distanciada dos seus interesses. As famílias, principalmente as das classes populares, são responsabilizadas pelas dificuldades de seus filhos, acusadas de pertencerem a uma cultura inadequada para o desenvolvimento das crianças, tomadas como incapazes para a tarefa de educar. Já os professores são encarados como incompetentes, com uma formação insuficiente para ensinar os alunos. Qualquer explicação dos fenômenos escolares que não assuma sua complexidade corre o risco de produzir análises simplistas, centrando-se na busca de "culpados", colaborando com a produção de equívocos e a manutenção de uma realidade desigual.

O aprendizado e a socialização do aluno são atravessados pelas crenças e percepções dos educadores. A subjetividade daquele que ensina influencia o olhar do aprendiz. Dessa forma, o professor tem papel fundamental, sendo a relação professor-aluno um núcleo das experiências de aprendizagem (TACCA \& GONZÁLEZ REY, 2008).

A escola, como um contexto rígido que busca a homogeneidade, compartilha uma concepção linear do aprender, tendo a psicologia assumido um papel na medicalização da vida com a produção de diagnósticos. Alunos que apresentam dificuldades em seu processo de escolarização têm sido encaminhados para clínicas psicológicas como portadores de problemas de aprendizagem, o que Meira (2012) chama de “epidemia de diagnósticos”. Essas práticas trazem desdobramentos éticos, já que muitos são medicados. Meira (2012) sugere um crescimento da indústria farmacêutica a partir desses diagnósticos, fomentado pela lógica capitalista. Surge uma reflexão: quem ganha com isso? Qual o compromisso dos psicólogos? Crianças medicadas tendem a se comportar melhor, ficam quietas, paralisadas, entorpecidas. Com os medicamentos, são enquadradas, tornam-se alunos obedientes. Esse quadro sinaliza a urgência da construção de diagnósticos comprometidos com as pessoas, o oposto do que tem sido feito a partir dos encaminhamentos das escolas, um processo aligeirado, que rotula qualquer comportamento dito inadequado como anormal.

Meira (2012) ressalta a problemática de como transtornos, tomados como mais comuns em sala de aula, vêm na contramão de um processo escolar que respeita a diversidade das experiências humanas. Os diagnósticos desses 
transtornos, muitas vezes, são construídos de forma artificial, a partir de questionários internacionais, como é o caso do TDAH (Transtorno de Déficit de Atenção e Hiperatividade), indicado para alunos que apresentam "falta de atenção, inquietude, impulsividade persistente”. O mesmo acontece com o TOD (Transtorno Desafiante de Oposição), com sujeitos que "contrapõem regras, desafiam ou aborrecem os adultos (ou terceiros) ”. Assim, observa-se que os transtornos estão virando explicações para as causas de comportamento desviantes ou fora do padrão estipulado pela escola.

Esta instituição tem exercido uma função de sequestro, ditando os comportamentos "adequados", formatando os pensamentos, produzindo estereótipos para aqueles que não se enquadram. A falta de envolvimento e interesse dos alunos pode ser uma evidência de como a escola está distante das suas necessidades, e não o diagnóstico de uma doença. É papel do professor tomar esses elementos como objeto de reflexão, como oportunidade de pensar novos caminhos para a organização do trabalho educativo (MEIRA, 2012). Para que as discussões na escola façam sentido para os alunos, é importante que os professores façam uma autoavaliação, analisem como o trabalho tem sido desenvolvido, quais temas têm sido priorizados, como se tem avaliado os processos de aprendizagens, entre outras questões. Um olhar sensível permite a construção de uma Pedagogia que toma as relações como elemento central, produzindo envolvimento com a proposta educativa.

A falta de uma análise crítica sobre o excesso de transtornos que têm surgido no ambiente escolar, e do processo de medicalização em decorrência disso, transforma os alunos em “pacientes potenciais” e isso, de fato, não irá resolver os problemas de aprendizado (MEIRA, 2012).

Tudo indica que nessa perspectiva as relações humanas entre professores e alunos na escola são pensadas apenas a partir de vínculos de dependência, estes sim patológicos porque altamente produtores de frustração e alienação. A ausência de reciprocidade e respeito mútuo impede a efetivação de relações saudáveis e humanizadoras. (...) estamos pedindo às crianças que prestem atenção em tudo o que lhes é apresentado, mesmo que esses conteúdos não façam o menor sentido! $\mathrm{E}$, ainda mais: que não se irritem com nada disso, mesmo que por vezes a situação lhes pareça insuportável! (MEIRA, 2012, p. 140).

Outra explicação para supostos problemas de aprendizagem, também dentro do paradigma biomédico, é identificado por Collares e Moysés (1994). As autoras afirmam, em suas pesquisas, que a desnutrição e as disfunções 
neurológicas vêm sendo destacadas por algumas escolas públicas e médicos, principalmente, como sendo um empecilho para o aprendizado das crianças. A “desnutrição” ou as “disfunções neurológicas”, segundo Collares e Moysés (1994), não configuram causas reais para um fracasso no aprendizado:

(...) Crianças que frequentam a rede pública de ensino, comumente rotuladas como desnutridas, são na verdade portadoras de desnutrição leve, de $1^{\circ}$ grau, que não trazem nenhum tipo de alteração para o sistema nervoso central. Além disso, as funções neurológicas que poderiam ser afetadas pela desnutrição nem sequer estariam presentes por volta de sete anos, não podendo, portanto, serem admitidas como explicações plausíveis para o não aprender (COLLARES \& MOYSÉS, 1994, p. 27).

Essas discussões apontam para a necessidade de reafirmação da escola como espaço plural, democrático, que permite os sujeitos a expressão, a invenção e a interação. Freire (1987) defende a existência de diversos ritmos e formas para aprender. $\mathrm{O}$ aprender demanda uma postura reflexiva, construída ativamente pelos sujeitos, e tem o diálogo como princípio para a construção do "pensar verdadeiro”, “pensar crítico” (FREIRE, 1987). Tal posicionamento toma as aprendizagens como processos sociais complexos, que partem das interações, dos significados culturais que os alunos atribuem ao seu redor. De acordo com Freire (1987), a educação problematizadora é um esforço permanente, e demanda respeito pelos sujeitos.

Dessa maneira, o educador já não é o que apenas educa, mas o que, enquanto educa, é educado, em diálogo com o educando que, ao ser educado, também educa. Ambos, assim, se tornam sujeitos do processo em que crescem juntos e em que os "argumentos da autoridade” já não valem. Em que, para ser-se, funcionalmente, autoridade, se necessita estar com as liberdades e não contra elas (FREIRE, 1987).

Freire (1987) cita que o saber autoritário não terá um bom caminho mediante as “identidades culturais” em sala de aula, é preciso atenção e sensibilidade por parte dos docentes, extrapolando o ensino dos conteúdos.

É uma pena que o caráter socializante da escola, o que há de informal na experiência que se vive nela, de formação ou deformação, seja negligenciado. Fala-se quase exclusivamente do ensino dos conteúdos, ensino, lamentavelmente quase sempre entendido como transferência do saber. Creio que uma das razões que explicam este caso em torno do que ocorre no espaço-tempo da escola, que não seja a atividade ensinante, vem sendo uma compreensão estreita do que é educação e do que é aprender (FREIRE, 1996, p. 19). 
Freire (1996), ao falar das exigências do ensino, traz a discussão do reconhecimento, do tomar para si, da apropriação do sujeito, entendendo que a educação tem como função possibilitar aos alunos as condições necessárias para a experiência de "assumir-se” como sujeito social e histórico, potente, capaz de se expressar, de interferir no mundo. Esse movimento não se dá na exclusão do outro, mas no entrelaçamento de outras culturas.

O desafio de se pensar uma educação dialógica, que respeite as experiências dos sujeitos não é pequena. Tacca e Gonzalez Rey (2008) chamam a atenção para o caráter compulsório da escola, com consequências importantes na vida dos alunos. Essa condição desigual é observada por Freire (1987) com a crítica de que as relações educacionais reproduzem a sociedade opressora com o silenciamento e o controle dos educandos. Nesse foi apresentado os desafios da escola na contemporaneidade, e a aceitação dessa realidade pode trazer prejuízos para a sociedade em termos de subjetividades e humanização, como a produção de pessoas negligenciadas com o uso de medicamentos, com baixa autoestima e uma criatividade anulada. É preciso que a escola seja um espaço de autoria, de encontro, de invenções, de produção de sentidos. Dessa forma, a educação tem como responsabilidade a inclusão de todos os alunos, com suas singularidades, deixando de lado perfis rígidos do que é ser um bom aluno, comprometida com o desenvolvimento integral dos sujeitos (MELO, SOUZA \& DAYRELL, 2012).

\section{1}

Práticas Pedagógicas Contemporâneas: Desafios da prática escolar e o processo de aprendizagem do aluno

Pesquisar sobre os processos de aprendizagens é olhar o campo educacional por vários ângulos. O aprendizado acontece em sala de aula pelos ensinamentos teóricos, também pela experiência e sentido que a escola tem para cada atuante. Com isso, surgem atravessadores e desafios nas relações. Castro (2013) ressalta que o lugar de centralidade que os professores ocupam traz uma responsabilidade nas decisões a serem tomadas. Seria de direito que eles pudessem ter um papel mais determinante nos conteúdos que são transmitidos em sala de aula, entende-se que, dessa forma, a relação com o conhecimento seria mais enriquecedora para todas as partes. 
O aprendizado requer a união de curiosidades, busca de significados e acolhimento dos erros e acertos que podem acontecer ao longo desse percurso. Freire (1997) aponta para caminhos diversos, enfatizando que soluções diferentes podem ser tomadas no percurso do aprendizado. $\mathrm{O}$ aprender e o ensinar caminham juntos, atrelados pela lógica do conhecimento. Um ensina ao outro da mesma forma que um aprende com o outro, numa relação contínua de troca. A lógica mecânica prevalecerá se o aprender e o ensinar andarem separados, se a forma de aprendizado passar por fixação ou repetição de dados.

Freire (1997) faz uma relevante ligação entre o ensinar e o aprender, enfatizando que nesse processo é necessário a atuação de quem aprende e de quem ensina, um voltado para o outro. O despertar para o conhecimento é acendido quando o professor está voltado para a curiosidade desse aluno e quando este percebe que o professor tem muito a lhe ensinar. A visão de Paulo Freire assume uma compressão da educação como um espaço de diálogo, crítica, problematização e do encontro com o outro. Para Arroyo (2001), a arte de ensinar está no encontro, no diálogo construído em sala de aula.

Ao falar de formas mais específicas de práticas pedagógicas utilizadas nas escolas, Freire (1997) discorre sobre atividades com leituras e como elas são importantes para a apropriação dos textos. Ele enfatiza que a leitura de mundo precede a leitura da palavra, valorizando as experiências dos educandos. Para ele, tomar a criatividade e a experiência do aluno como referências aos assuntos que serão abordados é fundamental no processo de aprendizagem. A aposta é na expressão dos alunos e dos professores a partir de diferentes linguagens, como, por exemplo, a arte que pode apoiar o processo de aprendizagem e a relação com a cultura. Professores bem formados e interativos com a matéria que estão lecionando direcionam o aprendizado para um caminho melhor de expressão. A escola não deve ser um peso para os sujeitos que ali estão, é preciso do estímulo às experiências para todos que estão envolvidos no processo escolar (FREIRE, 1997).

Em relação à leitura, o autor citado afirma:

Ler é uma operação inteligente, difícil, exigente, mas gratificante. Ninguém lê ou estuda autenticamente se não assume, diante do texto ou do objeto da curiosidade a forma crítica de ser ou de estar sendo sujeito da curiosidade, sujeito da leitura, sujeito do processo de conhecer em que se acha. Ler é procurar ou buscar criar a compreensão do lido (FREIRE, 1997, p. 20). 
Assim, o processo de leitura exige que o sujeito assuma o lugar de autor. A atenção voltada para o ler e o escrever no processo escolar, dentro dessa visão, aponta para uma compreensão dessas práticas como sociais, realizadas em situações reais e significativas, necessárias à interação entre os interlocutores. O professor assume uma posição importante como mediador nas experiências de leitura e escrita, apoiando os educandos na compreensão do conhecimento e envolvendo-os pela dimensão social e ideológica.

Professores inteirados das demandas que atravessam a infância e a adolescência, tornam essa relação mais próxima. Freire (1997) apresenta uma reflexão sobre essa relação:

A prática educativa (...) é algo muito sério. Lidamos com gente, com crianças, adolescentes ou adultos. Participamos de sua formação. Ajudamo-los ou os prejudicamos nesta busca. Estamos intrinsecamente a eles ligados no seu processo de conhecimento. Podemos concorrer com nossa incompetência, má preparação, irresponsabilidade, para o seu fracasso. Mas podemos, também, com nossa responsabilidade, preparo científico e gosto pelo ensino, com nossa seriedade e testemunho de luta contra as injustiças, contribuir para que os educandos vão se tornando presenças marcantes no mundo (FREIRE, 1997, p. 32).

Ainda sobre a relação professor-aluno, um processo escolar satisfatório não depende somente de uma das partes, é na interação que ocorre o processo escolar, no entrelaçar de mãos dos agentes inseridos num contexto social. Ou seja, são muitos os elementos necessários para um processo de aprendizagem significativo - o respeito aos sujeitos; a invenção, a curiosidade, o diálogo como princípios; a garantia de formação inicial e um serviço de qualidade para os professores; condições de trabalho para os docentes; uma escola com recursos diversificados, como livros, brinquedos, jogos, computadores etc.

Além desses pontos, Freire (1997) destaca a importância da "amorosidade" na profissão de professor e relaciona-a com o ato de ensinar que, para ele, é constitutivamente amoroso, o que significa incluir, acolher, integrar. Freire (1997) se refere a um amor lutador que o professor precisa ter: que luta pelo ensinar, luta por valorização de profissão e por uma educação mais humanizada; reafirmando seu posicionamento político para a educação.

Sobre formação docente, é importante sinalizar que essa profissão é constituída em meio a tensões e desafios. Para Arroyo (2001, p. 22), a discussão 
sobre o trabalho do professor precisa "trazer à cena o próprio ofício de mestre, a construção social desse profissional e do campo educativo”. Ou seja, é no interior da profissão que o docente constrói a sua identidade, articulado à dimensão política. A desvalorização docente e a sua falta de prestígio social colaboram para a construção do sentido desse ofício atualmente, como pode ser observado com a desqualificação do professor com baixas remunerações e com a demanda por um perfil superficial - simpatia, boa aparência, ser carinhosa no cuidado das crianças e amável no trato com as famílias.

Outro exemplo de desqualificação do professor, principalmente da educação infantil e das séries iniciais do Ensino Fundamental, é a prática de nomear as profissionais da educação como tia. Para Freire (1997), esta seria uma estratégia para fragilizar a profissão e a figura do professor como intelectual. Esse tratamento aponta para a compreensão de que qualquer pessoa pode ser tia, não sendo necessária uma formação específica, tornando a escola um lugar doméstico. O ser professora traz algumas exigências próprias da profissão como: a luta por melhores condições para trabalhar e a disciplina intelectual para permanentemente se qualificar.

Castro (2013) traz como reflexão a necessidade de transformações nas práticas pedagógicas distanciadas das ações que precisam ser realizadas. O discurso de mudanças na educação deve ser colocado em prática com o objetivo de transformá-la. Frente a "um cenário opressivo”, professores se veem em um lugar caótico, a tantas demandas e deveres, parecem não conseguir agir de forma efetiva e conjunta para uma mudança real no campo educacional. Nesse contexto, o sentido de ser cidadão e lutar por direitos é passado para os alunos, soa como demagógico, já que os próprios professores não conseguem se mobilizar e conquistar suas causas.

É notável a necessidade de consolidação do papel do professor em sala de aula. Estes estão cada vez mais sem saber como agir mediante a tanto descaso com a profissão. A precariedade e a falta de suporte para o trabalho pedagógico trazem um isolamento para os professores, podendo fortalecer práticas autoritárias diante da ausência de espaços coletivos de reflexão, de partilha e de crítica (ARROYO, 2001).

A descrença em relação à transformação no ambiente educacional ganha espaço mediante a falta de apoio das (supostas) políticas educacionais vigentes. O 
esforço necessário para essa transformação se depara com um abismo social onde a mobilização e o fortalecimento se tornam ínfimos mediante aos obstáculos da escola pública, por exemplo (CASTRO, 2013). A falta de material para trabalhar temas importantes, más condições de estrutura, a desmotivação dos professores, entre outros fatores corroboram para um aprendizado fraco e sem sentido.

Contudo, a tolerância e a humildade precisam fazer parte do processo escolar, fortalecendo um contexto de aceitação das diferenças, de trocas, de busca de humanização na escola. Nesse sentido, Freire (1997) afirma:

$\mathrm{O}$ ato de tolerar implica o clima de estabelecimento de limites, de princípios a serem respeitados. Por isso a tolerância não é conivência com o intolerável. Sob regime autoritário, em que a autoridade se exacerba ou sob regime licencioso, em que a liberdade não se limita, dificilmente aprendemos a tolerância. A tolerância requer respeito, disciplina, ética.

Assim, defende- se que o processo escolar caminha com a tríade: aluno, professor e escola, num clima solidário, construído coletivamente. O aprendizado avança de acordo com os sentidos das relações estabelecidas na escola sendo responsabilidade dos alunos e dos professores o desenvolvimento do aprendizado (FREIRE, 1997). Nesse processo, é importante ressaltar seu caráter dialógico, já que os professores não são detentores absolutos do saber, que possuem limites, dúvidas e até mesmo desconhecimento.

\begin{abstract}
O melhor é dizer aos educandos, numa demonstração de que somos humanos, limitados, o que experimentamos na hora. É falar a eles sobre o próprio direito ao medo, que não pode ser negado à figura da educadora ou do educador. Tanto quanto o educando, eles têm direito a ter medo. O educador não é um ser invulnerável. É tão gente, tão sentimento e emoção quanto o educando. O que contraindica, em face ao medo, a ser educador, é a incapacidade de lutar para sobrepujar o medo e não o fato de tê-lo ou de senti-lo. O medo de como se sair no seu primeiro dia de aula diante, muitas vezes, de alunos já experimentados e que adivinham a insegurança do professor novato é algo mais do que natural (FREIRE, 1997).
\end{abstract}

A insegurança faz parte da sala de aula e é importante que se possa expressar os medos a fim de viabilizar o sentimento de confiança entre professores e alunos. Esse clima de diálogo pode colaborar com os processos de subjetivação. Assim, professores atentos a si mesmos e aos estudantes, a cada gesto, saberes, conhecimentos, introversões ou transgressões, podem tornar o espaço da sala de aula rico além de fortalecer os sujeitos em seus processos de aprendizagem e em sua capacidade de ação no mundo (FREIRE, 1997). 
Creio que a questão fundamental diante de que devemos estar, educadoras e educadores, bastante lúcidos e cada vez mais competentes, é que nossas relações com os educandos são um dos caminhos de que dispomos para exercer nossa intervenção na realidade a curto e a longo prazo. Neste sentido e não só neste, mas em outros também, nossas relações com os educandos, exigindo nosso respeito a eles, demandam igualmente o nosso conhecimento das condições concretas de seu contexto, o qual os condiciona. Procurar conhecer a realidade que vivem nossos alunos é um dever que a prática educativa nos impõe: sem isso não temos acesso à maneira como pensam, dificilmente então podemos perceber o que sabem e como sabem (FREIRE, 1997).

Um ambiente plural tem espaço para a imaginação, tão importante na vida do sujeito. A imaginação circulando em sala de aula instiga a criatividade, e a inventividade pode apoiar a expressão dos alunos através do corpo, da dança, das artes plásticas, da poesia e de linguagens. São caminhos para explorar a imaginação, as aprendizagens, a autoria nas experiências escolares. Dessa forma, o aluno assume um posicionamento frente ao mundo, não reproduzindo de forma mecânica teorias, livros e autores sem uma apreciação crítica. Freire (1997) diz que a imaginação está relacionada aos sonhos, a possibilidade de construir uma escola democrática, sendo este um desafio:

Numa sociedade como a nossa, de tradição tão robustamente autoritária, é algo de relevante importância encontrar caminhos democráticos para o estabelecimento de limites à liberdade e a autoridade com que evitemos a licenciosidade que nos leva ao "deixa como está para ver como fica" ou ao autoritarismo todo poderoso (FREIRE, 1997).

Freire (1997) descreve uma educação cerceadora como a que impõe aquilo que os professores podem ou não dizer na sala de aula, impulsionando uma sociedade a caminhar para a limitação do pensamento, do questionamento, da curiosidade. Aponta a contradição do ensino quando os alunos não podem questionar o que os próprios professores ensinam e vivem. “À prática educativa em que inexiste a relação coerente entre o que a educadora diz e o que ela faz é, enquanto prática educativa, um desastre” (FREIRE, 1997, p. 51). Os professores passam a ter uma dualidade em sala de aula longe da clareza e expressividade que este local pede. As relações se deterioram mediante a um ambiente cerceador e trazem à tona uma das fragilidades da educação brasileira - uma escola que robotiza alunos e professores, prejudicando suas capacidades de expressão, de dialogar ou se comunicar - "Escola silenciosa é a negação da vida e da pedagogia" (ARROYO, 2001). 
A invisibilidade das pessoas dentro da escola pode ser exemplificada a partir dos modelos de avaliação que focam nos resultados, utilizando provas e testes como parâmetros únicos, o que significa "abandonar o trato pedagógico" (ARROYO, 2001, p. 44). Essa tentativa de homogeneização por meio de práticas disciplinares e avaliativas comprometem o desenvolvimento de um sujeito crítico, inviabilizando um processo de aprendizagem baseado nas invenções e nas trocas.

Essa precariedade nas relações interpessoais e com os conhecimentos comprometem o processo de humanização na escola. Aprendemos e nos transformamos nas trocas, na interação, nas expressões, na produção de significados e nos novos aprendizados. Freire (1997) enfatiza a centralidade das relações na escola, dos modos de partilha dos conhecimentos socais e culturais. Ele afirma que "no fundo, nem somos só o que herdamos nem apenas o que adquirimos, mas a relação dinâmica, processual do que herdamos e do que adquirimos” (FREIRE, 1997, p. 63).

Para Arroyo (2001), a capacidade de escuta e o olhar sensível são tarefas do professor para a construção de um ambiente acolhedor e rico. Um dos objetivos do ofício de ser professor é o suporte à formação das subjetividades dos alunos. É comum observar o desinteresse por parte de alguns deles, o que pode trazer questionamentos sobre a qualidade das interações estabelecidas. Como resposta ao não envolvimento dos alunos, recorre-se à justificativa da ausência de interesse pelo estudo, sem nenhuma crítica ao trabalho pedagógico, produzindo estereótipos sobre os estudantes. Essa postura fortalece a apatia em sala de aula, com professores insatisfeitos e alunos desmotivados pela escola.

O clima escolar burocrático, normatizado, a organização disciplinar e gradeada nos levam a representar apenas nosso papel de transmissores, se possível competentes. Negamos a possibilidade de dar o salto para uma relação pedagógica, fazer de nossa prática uma relação, uma interação entre gerações. Revelar-nos (ARROYO, 2001).

O presente trabalho aposta nas artes como possibilidade para questionar a rigidez escolar, modelo baseado na racionalidade técnica, trazendo a dimensão do sensível, do encontro com a cultura como essencial para a formação humana. De acordo com Arroyo (2001, p. 149):

(...) sabemos que as artes, os corpos, os sentimentos, as pulsações, o imaginário... têm sido as dimensões do ser humano mais controladas nas teorias pedagógicas, nas instituições educativas. As mais ignoradas nos currículos. Possivelmente 
porque não cabem em paredes, resistem a ser gradeadas e disciplinadas. Os projetos inovadores recuperam essas dimensões da condição humana como direitos, como componentes da humana docência, não como temas transversais (...), mas como direitos dos educandos e dos educadores. Essas transgressões de corpo inteiro mexem com o corpo inteiro dos mestres. Se descobrem humanos por inteiro.

As “posições cristalizadas” dentro da escola precisam ser questionadas e modificadas por alunos e professores no entendimento de que a escola é espaço também, para transgressões, rebeldia e caos (CASTRO, 2013, p.69). Para que essa educação libertária, questionadora, crítica e humanizadora seja colocada em prática, é necessário espaço para que os alunos e professores consigam alcançar suas demandas individuais. 


\section{O Encontro com a Arte no Contexto Escolar}

O atravessamento das relações escolares entende a arte como ponto importante para este estudo. A arte é uma das grandes formas de expressão da vida, consequentemente, é uma oportunidade de expansão do conhecimento e da criatividade nos processos cognitivos aos atuantes no ambiente escolar. Caminhos de sensibilização, construção e transformação podem ser alcançados pelo acesso às práticas artísticas. Para que isso aconteça, é necessário que a escola e os professores se atentem para o papel que também lhes cabe como mediadores da cultura e do conhecimento.

Vygotsky (2009) traz a importância da imaginação na construção da realidade e das relações cotidianas vitais no processo de produção de subjetividade dos sujeitos que conseguem criar e são incentivados a partir dessa atividade. É importante destacar que, para o autor, a emoção traz relação direta com esse processo de criação nas diferentes formas de experimentar a arte - na expressão do desenho, na pintura, no teatro, na música, nos movimentos corporais e na dança, tendo uma função humanizadora. A arte deve trazer à tona as contradições, ambivalências do humano - produzir prazer, horror, angústia, excitação, movimento, dúvidas, espanto com o feio, deslumbre com o belo. Dessa forma, tem colaborado com a produção de novos paradigmas para a compreensão de questões humanas. Para Vygotsky (2013), uma expressão maior do sentir.

Vygotsky (2009) argumenta que “a imaginação, na qualidade de atividade humana afetada pela cultura, pela linguagem, vai sendo marcada pela forma racional de pensar, historicamente elaborada”. Mais uma vez, aparece o sujeito como ativo na elaboração das suas relações com o outro e com a cultura, construindo suas subjetividades pelas suas interações com o mundo.

As experiências são recriadas ao longo do desenvolvimento, através das experiências já vivenciadas pelo sujeito. Para se criar algo, é preciso acessar a capacidade imaginativa, o terreno onde a fantasia prevalece. Grandes obras partem da união de algo existente da realidade com a capacidade criativa de se criar algo. Vygotsky (2009, p. 15-16) traz como exemplo “um pedaço de pau com 
as pontas calcinadas de fogo que foram transformadas naquilo que podemos chamar hoje de energia elétrica”, obras artísticas vieram de notáveis invenções, tais exemplos são citados por aliar a capacidade de criar e a técnica para o funcionamento de algo.

Aprender com brincadeiras pode ser um bom caminho para dar espaço aos modos de existir da criança - o ser criança dentro do processo de aprendizagem. Desse modo, ocorre uma quebra dos mecanismos cristalizados de se passar o conhecimento e viabiliza-se à criança dar o seu sentido no que está aprendendo. A ressignificação pelo mundo da criança, na forma de brincadeira é “a criação de uma nova relação entre o campo do significado e o campo da percepção visual” (SOUZA, 1996). No mundo infantil, as brincadeiras estão diretamente ligadas à capacidade imaginativa da criança. O encantamento infantil, às vezes com caixas de brinquedos ou utensílios da casa, por exemplo, retratam bastante o ato de criação a partir de um objeto que já é conhecido, mas a criança o transforma nos mais variados personagens (VYGOTSKY, 2009).

Castro (1998) faz um contraponto para um possível corte na capacidade imaginativa da criança, em suas comemorações de aniversário, por exemplo, onde tudo é altamente produzido e organizado com ares de espetáculo. Os “atores” mirins contam com brincadeiras direcionadas, tudo organizado de maneira que não fuja ao roteiro. Com isso, tudo o que se espera de criatividade, espontaneidade, fantasia, é abafado logo cedo.

Atento ao processo de desenvolvimento infantil, Vygotsky (2009) cita a capacidade das cristalizações que ocorrem na infância com o contraponto crítico que a imaginação pode deixar a criança distante da realidade. Ele argumenta, ainda, como a sua função na construção da subjetividade:

\footnotetext{
"Como a imaginação se apoia na experiência; como a experiência se apoia na imaginação; como a emoção afeta a imaginação e como a imaginação provoca as emoções. Argumenta ainda que a imaginação, na qualidade de atividade humana afetada pela cultura, pela linguagem, vai sendo marcada pela forma racional de pensar, historicamente elaborada" (VYGOTSKY, 2009, p. 9).
}

A escola é fundamental nesse processo de expansão da arte, se estiver atenta como a prática artística está sendo ensinada na sala de aula. Outras disciplinas podem caminhar em conjunto com a matéria de artes, proporcionando aos alunos diferentes caminhos para o aprendizado. 
Vygotsky (2009, p. 8) sinaliza a relação da interação social nas funções mentais superiores com o uso dos signos nas interações, que agem como mediadores das relações sociais e dos modos de comunicação com o mundo. A importância vem pela consciência da criança na formulação da linguagem, pelo uso das palavras para comunicar as experiências e os significados do mundo que a cercam. Os signos estão ligados ao processo de imaginação e simbolização das crianças, sendo estes importantes aliados no desenvolvimento mental, social e individual.

A arte de mediar leitura e contar histórias do repertório da oralidade na sala de aula, a partir de uma figura ou de um personagem, incentiva o aluno a recriar, estimulando a criatividade por meio de recursos lúdicos para novas experiências. Já as atividades de escrita, dissociadas das aulas de português e entendidas como arte literária (arte da palavra), estão internamente ligadas à capacidade de interpretação sobre o que se escreve, podendo servir de importante apoio às demais disciplinas. O incentivo à expressão e à imaginação favorecem o letramento. Escrever sobre temas pré-determinados, ditados por professores ou pelos livros, sem ter compreensão sobre o assunto, pode levar os alunos a um péssimo resultado nas suas produções.

É vantajoso que, na aprendizagem, os processos de criação, ou seja, a atividade artística esteja atrelada ao aprendizado. Desse modo, entrelaça-se a capacidade de aprender e as diversas formas de imaginar relacionadas ao conhecimento das matérias em sala de aula (VYGOTSKY, 2009).

Educação, entendida correta e cientificamente, não significa infundir de maneira artificial, de fora, ideais, sentimentos e ânimos totalmente estranhos às crianças. A educação correta consiste em despertar na criança aquilo que existe nela, ajudar para que isso se desenvolva e orientar esse desenvolvimento para algum lado (VYGOTSKY, 2009, p. 72).

Eisner (2008) aponta que a arte traz ensinamentos para a vida, a expressão requer sentimento e com isso, a arte une o sentimento ao pensamento. Quando se faz um trabalho de artes, une-se o cognitivo aos sentimentos, promovendo uma produção interessante para o sujeito que realiza. Eisner (2008) chama a atenção para a base que isso pode dar ao aluno, de atentá-lo sobre a necessidade de ser ativo nas suas elaborações e poder exercitar essa elaboração unindo o sentimento ao pensamento, tornando assim, a experiência valiosa. 
A arte e a educação podem ter uma aliança favorável e beneficiar o aluno. Hoje, em sala de aula, fala-se muito em controle, que é responsabilidade do professor em dominar a turma. Entende-se a importância de tal feito pois talvez sem um mínimo de controle, ele não teria como ministrar aulas. A arte vem para mostrar o novo e o que se pode produzir mediante um suporte em branco, a descoberta, a exploração, caminhos fundamentais na educação (EISNER, 2008).

A nossa inclinação para o controle e previsão é, num nível prático, compreensível, mas também exige um preço; nós tendemos a fazer coisas que sabemos como prever e controlar. Abrir-se à incerteza não é uma qualidade penetrante do nosso ambiente educacional corrente. Eu acredito que ela precisa de estar entre os valores que nós amamos. A incerteza precisa de ter o seu próprio lugar nos tipos de escola que nós criamos (EISNER, 2008).

A obrigatoriedade e a rigidez, muitas vezes, passeiam na sala de aula e se impõem como método de ensino, ainda nos dias de hoje. Para Eisner (2008), a arte vem para contrapor essa rigidez e demonstrar que a aspereza só endurece o ensino e o transforma em algo que os alunos abominam. Nesse caminho, o autor escreve:
A imaginação não é um mero ornamento, tal como a arte. Juntas podem libertar- nos dos nossos hábitos enrijecidos. Elas podem ajudar-nos a restaurar um propósito decente para os nossos esforços e a criar o tipo de escolas que as nossas crianças merecem e que a nossa cultura precisa. Tais aspirações, meus amigos, são estrelas pelas quais vale a pena esticar-se.

A arte pode ser uma importante ferramenta da escola permitindo uma maior integração dos alunos, palco para a expressão dos afetos que atravessam as experiências em sala de aula. As atividades artísticas permitem a expressão de sentimentos e de práticas. Assim, contribui para integração das dimensões psicológica e física dos alunos no processo escolar de aprendizagem (EISNER, 2008).

A atenção que a arte desperta no sujeito leva-o ao entendimento dos detalhes, a encontrar nuances, a dar vazão a sentimentos e emoções, pontos essenciais para tornar as experiências enriquecedoras. Um pensamento crítico requer do sujeito ir além da forma, do que se é falado, é preciso duvidar. A arte chama o olhar para a subjetividade, cada sujeito que entra em contato com ela encontrará a sua forma de entendimento do que está expresso.

Nesse contexto, a autonomia pode ser apreendida através da arte, que oferece como passo fundamental a elaboração de algo que não está 
predeterminado. A arte pode trazer à tona um conhecimento além do que se é estudado e repetido em sala de aula, pode levar o aluno a dar um novo sentido à expressão e ensiná-lo a significar o que está ao redor dele (EISNER, 2008).

Mas, afinal, qual o lugar que o ensino da arte ocupa nos currículos regulares? Uma reflexão que Barbosa (1989) trazia há 30 anos, em relação ao estudo das artes é que matérias que envolvem a apreciação artística e a História da Arte não tinham lugar na escola, não eram avaliadas com os mesmos critérios que disciplinas como matemática e português, deixando um vácuo no processo de aprendizagem do aluno.

Barbosa (1989) alertava que isto se dá pela falta de valorização da arte nos espaços cotidianos o que acabava se refletindo nas escolas, quando a arte não tinha encontrado um espaço de produção definido, como se os profissionais que ali atuavam não percebessem a larga extensão que a arte poderia alcançar e que não estava separada da cultura em que todos nós estamos inseridos. A arte está em todo lugar, portanto a sociedade sofre influência, todo o tempo, por meio de percepções visuais, linguísticas, táteis, sonoras que estão no cotidiano de cada um. Utilizar estes impulsos no ambiente escolar como meios para se alcançar subjetividades individuais e coletivas e proporcionar a explosão de opiniões, expressões e sensibilidades, é um caminho para que a escola tenha um sentido mais autêntico para os agentes que nela estão inseridos. 


\section{5}

\section{O estudo e seus objetivos}

O presente estudo parte de uma abordagem qualitativa, por meio da interlocução com os relatos dos alunos e professores de escolas públicas e particulares, a fim de verificar a relação estabelecida entre professores e alunos nas salas de aula escolares e o papel da afetividade no processo de aprendizagem. Também foram apresentados os resultados de dados quantificados da escala School Climate Survey - Revised, Elementary and Middle School Version (SCSMS), adaptada por Petrucci et al. (2016) ${ }^{2}$, sobre o clima na escola através da percepção dos alunos de seis dimensões: justiça; ordem e disciplina; o envolvimento dos pais; partilha de recursos; relações interpessoais e relação aluno-professor (PETRUCCI et al., 2016).

Nesse entendimento, a pesquisa de campo no ambiente escolar, com os sujeitos que compõem o processo de aprendizado pode ser considerada promissora para um estudo que pretende investigar, com maior profundidade, o tema da relação professor-aluno e as experiências de aprendizagem. Arroyo (2001, p. 10) explica que "toda relação educativa será o encontro dos mestres do viver e do ser com os iniciantes nas artes de viver e de ser gente. Os mestres no centro da Pedagogia, não (nos) apêndices”. Faz-se mister, a fim de evitar o julgamento e a culpabilização do fracasso da educação, olhar de forma mais atenta e sensível para os agentes que estão engajados nos processos de aprendizagem os professores, alunos e demais integrantes da escola.

Freire (1997) ressalta que o discurso atual, chamado de "modernizante" para alguns, deixa de lado a formação de uma sociedade e as responsabilidades que sobressaem nessa formação: a cultura, o cotidiano e a produção da vida. Fazse necessário arrancar as máscaras dessa "ideologia modernizante” que quer pairar sobre a educação. Por mais utópico que soe essa discussão, formar uma sociedade requer que se tenha sonhos além dos muros da escola, e que a escola junto com os cuidadores sejam a base desse processo que acompanhará todos os sujeitos em sua formação escolar e pessoal (FREIRE, 1997).

\footnotetext{
${ }^{2} \mathrm{O}$ instrumento está disponível para leitura no campo dos anexos.
} 
A escola tem relevância social, e é um lugar em que as crianças passam grande parte do seu tempo. Muitos ingressam ainda bebês e permanecem até a adolescência. Tal contexto tem um papel de grande importância e responsabilidade na vida dos sujeitos ali inseridos. A Psicologia tem se dedicado a pensar diferentes aspectos da escola, contribuindo para refletir sobre os desafios educacionais contemporâneos. O período escolar precisa ser considerado de suma importância na vida da criança e do jovem. Para o entendimento do processo escolar, faz-se necessário um número significativo de pesquisas científicas atuais que busquem investigar a relação interpessoal e a expressão em sala de aula. 


\section{Metodologia}

O projeto foi submetido e aprovado pelo Comitê de Ética da PUC-RIO (2017-18). A inclusão na amostra foi condicionada à assinatura do Termo de Consentimento Livre e Esclarecido ${ }^{3}$ e o Termo de Assentimento para os alunos ${ }^{4}$.

Participaram do estudo quatro escolas: duas públicas e duas particulares, todas localizadas no bairro de Botafogo, na cidade do Rio de Janeiro. Desde o início desta pesquisa, percebeu-se a importância de pesquisar escolas públicas e privadas com o objetivo de se ter uma amplitude maior de experiências e diversidades. Houve tentativas em mais quatro escolas privadas ${ }^{5}$, que se negaram a participar do estudo.

O procedimento para o convite à participação das escolas particulares foi agendar uma reunião com a coordenadora ou diretora previamente por telefone ou e-mail. No dia da reunião, o projeto da pesquisa foi apresentado e foi entregue uma carta assinada pelo Programa de Pós-Graduação da PUC-RJ que identificava a pesquisadora como aluna do Mestrado. Foram dadas explicações detalhadas sobre as entrevistas que seriam realizadas com os alunos e professores do $7^{\circ}$ ano $\mathrm{e}$ do $9^{\circ}$ ano - segmentos escolhidos por acreditar-se que os alunos do $7^{\circ}$ ano, segundo ano do ensino fundamental II e os do $9^{\circ}$ ano, último ano do ensino fundamental II, compartilhariam experiências diversas, o que poderia contribuir para uma amplitude maior ao objetivo do estudo. No primeiro encontro, a pesquisadora esclareceu qual era o objetivo de sua pesquisa e mostrou os termos de consentimento dirigidos aos responsáveis e aos participantes. Mesmo assim, a direção das escolas mencionou a dificuldade de entrevistar os alunos por serem menores de idade e terem que acionar os pais com os termos. Foi necessário explicar a importância para a área da educação de uma pesquisa atenta às relações em sala de aula e à influência destas no aprendizado, componentes fundamentais para o funcionamento qualitativo da escola. Após a compreensão, as gestoras concordaram com a realização da pesquisa.

\footnotetext{
${ }^{3} \mathrm{O}$ modelo dos termos encontra-se no campo dos anexos para visualização.

${ }^{4} \mathrm{O}$ modelo dos termos encontra-se no campo dos anexos para visualização.

${ }^{5}$ Três-dessas escolas são localizadas na zona norte e a outra na zona Sul, do Rio de Janeiro.
} 
Com isso, foi solicitado um tempo para a pesquisadora levar a pesquisa aos diretores, deixar o projeto na escola e aguardar a resposta, sem expectativas. Houve, de fato, negativas. Algumas coordenadoras que se negaram a participar explicaram que o responsável estava ausente da instituição, não havendo possibilidade de a pesquisa ser realizada naquele período. As respostas negativas mais diretas para a pesquisa não tiveram justificativa detalhada.

No caso das escolas da rede pública de ensino, o primeiro passo foi visitálas e definir em quais delas as entrevistas seriam feitas. Foram escolhidas duas escolas públicas no bairro de Botafogo a fim de se ter uma diversidade de comunidades escolares. As coordenadoras explicaram sobre a necessidade de ir até a Secretaria Municipal de Educação para dar entrada no pedido de pesquisa. Só após a devida autorização seria possível realizar a pesquisa na escola. $\mathrm{Na}$ Secretaria Municipal de Educação, foi preciso deixar o projeto, uma carta de apresentação assinada pela Pontifícia Universidade Católica (PUC-Rio), preencher um formulário com os dados da pesquisa e os nomes das escolas que seriam pesquisadas. Pedido aprovado depois de um mês, fui encaminhada para a $2^{a}$ Coordenadoria Regional de Educação (CRE) referente às escolas para entregar a autorização de pesquisa. A partir desse momento, foi possível iniciar as entrevistas nas escolas públicas.

Entre privadas e públicas, cerca de 17 entrevistas foram realizadas ao longo de 40 dias em cada escola, sendo necessárias duas visitas por semana, em turnos alternados (manhã e tarde).

As idas às salas de aulas para falar da pesquisa e buscar os participantes foram previamente marcadas com as coordenadoras nas quatro escolas. Em alguns casos, fui acompanhada, em outros fui sozinha, com a autorização do professor da turma para falar sobre a pesquisa. Foi necessária uma apresentação breve, para explicar os motivos e os objetivos da pesquisa: conhecer a relação com os professores e a influência deste contato com o aprendizado da disciplina. Os alunos foram informados também os métodos que seriam utilizados na pesquisa: entrevistas gravadas e um questionário sobre o clima escolar, no formato de múltipla escolha. A maioria dos professores demonstrou interesse na pesquisa e corroborou a importância da participação dos alunos. O termo para o consentimento do responsável foi encaminhado previamente pela agenda a cada 
aluno, que deveria retornar assinado em data combinada, o que nem sempre ocorreu.

Tabela 1: Participantes.

\begin{tabular}{|c|c|c|}
\hline $\mathbf{4 8}$ alunos & $\mathbf{2 3}$ professores & $\mathbf{4}$ escolas \\
\hline $\begin{array}{c}27 \text { alunos da escola } \\
\text { particular }\end{array}$ & $\begin{array}{c}11 \text { professores } \\
\text { da escola particular }\end{array}$ & 2 escolas particulares \\
\hline $\begin{array}{c}21 \text { alunos da escola } \\
\text { pública }\end{array}$ & $\begin{array}{c}12 \text { professores } \\
\text { da escola pública }\end{array}$ & 2 escolas públicas \\
\hline
\end{tabular}

Participaram da pesquisa 48 alunos, sendo 21 alunos das escolas públicas e 27 das escolas particulares. Dentro dos 48 alunos, 19 eram meninos e 29 eram meninas; 35 alunos cursavam o $7^{\circ}$ ano e 13 alunos cursavam o $9^{\circ}$ ano do Ensino Fundamental II. O intervalo das idades das crianças foi de 11 a 16 anos. No grupo dos professores, participaram 23 professores, sendo quatro homens e 19 mulheres. Foram entrevistados professores de Artes Plásticas, Ciências, Design ${ }^{6}$, Educação Física, História, Inglês Literatura, Matemática, Português e Redação. Dos 23 professores entrevistados, 16 tinham mais de dez anos de carreira; quatro professoras tinham entre cinco e dez anos de carreira; uma professora da escola particular tinha menos de um ano no magistério; e duas professoras do ensino público estavam prestes a se aposentar. Quatro escolas participaram do estudo. Denominou-se A e B para as escolas públicas e C e D para as escolas particulares. As entrevistas individuais com os alunos na escola pública que aqui chamaremos de A foram realizadas no corredor ou em alguma sala de aula vazia. Na maior parte das vezes a sala disponível era a de Artes. Na escola pública que aqui chamaremos de B, foi disponibilizada uma sala para as entrevistas com os alunos. Na escola particular que aqui chamaremos de C, as entrevistas foram realizadas na biblioteca, na maior parte das vezes. Na escola particular que aqui chamaremos de D, foi disponibilizada a sala das psicólogas para as entrevistas com os alunos.

Com os professores, houve uma apresentação rápida da pesquisa na sala dos professores, com um detalhamento sobre a pesquisa e os métodos utilizados

\footnotetext{
${ }^{6}$ Na escola C, o $9^{\circ}$ ano tem aulas de design, prática bem próxima ao trabalho da disciplina Artes Plásticas das outras escolas pesquisadas.
} 
com cada professor. Todos demonstraram interesse inicialmente, sendo que não foi possível encontrar um horário compatível com dois professores da Escola C, para a realização da entrevista. Apenas um professor consultado da Escola A disse que não tinha interesse em responder.

Dos 23 professores participantes, 12 professores pediram para ver o projeto, oito das escolas públicas e quatro das escolas particulares.

O tempo total das entrevistas com os alunos foi de três horas e 15 minutos, uma média de quatro minutos por aluno, e com os professores, de seis horas e 28 minutos, uma média de 16 minutos por professor.

Em relação aos procedimentos de pesquisa, foi utilizado com os alunos, o instrumento School Climate Survey - Revised, Elementary and Middle School Version (SCS-MS), adaptado por Petrucci et al. (2016) ${ }^{7}$, que avaliou o clima na escola através da percepção dos alunos sobre as já citadas seis dimensões. Também foram realizadas entrevistas com os alunos a partir de um roteiro semiestruturado compostas por seis questões abertas, buscando saber sobre o processo de aprendizado, opiniões e sugestões referentes à relação professoraluno. As questões priorizam os seguintes pontos:

1- Quais os professores que você mais gosta?

2- Como é sua relação com o professor que você mais gosta?

3- O que é ser um bom professor para você?

4- Como você é em sala de aula? (Participa das aulas, dá opinião nas aulas, presta atenção no que o professor está dizendo?)

5- Como é a sua relação com seus professores? Você considera importante essa relação para o seu aprendizado?

6- Como você se sente na escola? (Gosta de estar aqui?)

Com os professores, foi realizada uma entrevista semiestruturada, composta por seis questões abertas, buscando saber sobre como se estabelece o processo de aprendizado, as opiniões, sugestões referentes a relação professoraluno. O roteiro abordou as seguintes perguntas:

1 - Para você, o que é ser professor?

2- Como você se sente em sala de aula?

3- O que é ser um bom professor para você?

\footnotetext{
${ }^{7} \mathrm{O}$ instrumento está disponível para leitura no campo dos anexos.
} 
4- Como é a sua relação com os seus alunos?

5 - O que você considera uma aula interessante para manter o aluno focado na disciplina?

6- O que você acha da relação professor-aluno no processo de aprendizagem?

As entrevistas buscaram dar uma visibilidade para o campo teórico que este estudo buscou como embasamento. Dessa forma, elas permitiram um diálogo com os sujeitos, uma aproximação de aspectos polêmicos, ambiguidades e desafios do tema estudado.

\section{1}

\section{Procedimentos de análise dos dados}

As entrevistas com os alunos e professores foram gravadas e transcritas.

No que se refere à entrevista, foi necessária uma técnica de tratamento de dados, com análises das respostas apresentadas pelos entrevistados através do Mapa de Associações de Ideias, apresentado por Spink (1999). Este tem como objetivo sistematizar o processo de análise das práticas discursivas de forma a dar subsídios ao processo de interpretação. Ou seja, divide-se o mapa, a partir da definição de categorias gerais voltadas para o objetivo do estudo, onde se organiza o conteúdo apresentado, seguindo a sequência das falas. Dessa forma, o diálogo mantém-se intacto quanto à ordem em que o sujeito fala, sendo apenas disposto nas colunas referentes a cada categoria. Esse instrumento possibilitou a separação das falas a partir do que se deseja estudar, facilitando o processo de compreensão e construção do saber. 


\section{Resultados}

\section{1}

\section{Entrevistas}

Entrevistar os alunos e professores foi fundamental para entender melhor as relações escolares. Peças fundamentais nesse ambiente, alunos e professores se unem em busca de motivações e objetivos, na escola. A análise das entrevistas foi organizada nas tabelas a seguir com o objetivo de agrupar e trazer as respostas que mais sobressaíram no processo das entrevistas.

Tabela 2: Entrevistas: Alunos.

\begin{tabular}{|c|c|c|}
\hline & Escola Pública - A, B & Escola Particular - C, D \\
\hline $\begin{array}{c}\text { Características dos } \\
\text { professores que mais gostam }\end{array}$ & $\begin{array}{l}\text { Divertidos e pacientes na hora } \\
\text { de explicar }\end{array}$ & Divertidos e flexíveis \\
\hline $\begin{array}{l}\text { Relação com os professores } \\
\text { que mais gostam }\end{array}$ & $\begin{array}{l}\text { Vínculo quando percebem } \\
\text { atenção principalmente nas } \\
\text { dificuldades escolares }\end{array}$ & $\begin{array}{l}\text { Vínculo de troca e de } \\
\text { experiências }\end{array}$ \\
\hline Bom professor & $\begin{array}{l}\text { Afetivo e perceptivo nas } \\
\text { dificuldades dos alunos }\end{array}$ & $\begin{array}{l}\text { Afetivo e o que se coloca na } \\
\text { relação com os alunos (vão } \\
\text { além de ser professor) }\end{array}$ \\
\hline $\begin{array}{c}\text { Relação com todos os } \\
\text { professores e a relação com } \\
\text { o aprendizado }\end{array}$ & $\begin{array}{c}\text { “Normal” e tem influência no } \\
\text { aprendizado }\end{array}$ & $\begin{array}{l}\text { Boa e tem influência no } \\
\text { aprendizado }\end{array}$ \\
\hline Sentimento na escola & Bom e com segurança & $\begin{array}{l}\text { O acolhimento e o afeto foram } \\
\text { mais mencionados no contexto } \\
\text { em que a arte é um eixo do } \\
\text { trabalho educativo. }\end{array}$ \\
\hline $\begin{array}{c}\text { Como se descrevem em sala } \\
\text { de aula }\end{array}$ & $\begin{array}{c}\text { Gostam de conversar com os } \\
\text { amigos em sala de aula e } \\
\text { tímidos na hora de tirar as } \\
\text { dúvidas }\end{array}$ & Participativos \\
\hline
\end{tabular}


Tabela 3: Entrevistas: Professores.

\begin{tabular}{|c|c|c|}
\hline & Escola Pública - A, B & Escola Particular - C, D \\
\hline O que é ser professor & $\begin{array}{l}\text { Transmitir o conhecimento e } \\
\text { alcançar o aluno pelo afeto }\end{array}$ & $\begin{array}{c}\text { Mediar o conhecimento e ser } \\
\text { responsável em estabelecer } \\
\text { vínculo e afeto }\end{array}$ \\
\hline Sentimento em sala de aula & $\begin{array}{c}\text { Se sentem cansados, } \\
\text { frustrados, mas realizados } \\
\text { profissionalmente - misto de } \\
\text { sentimentos }\end{array}$ & $\begin{array}{c}\text { Se sentem bem e } \\
\text { comprometidos com o que } \\
\text { fazem }\end{array}$ \\
\hline Bom professor & $\begin{array}{l}\text { Sensível e que busca entender } \\
\text { o aluno - levando em } \\
\text { consideração a vida do aluno }\end{array}$ & $\begin{array}{l}\text { Capaz de incentivar seus } \\
\text { alunos, disponível }\end{array}$ \\
\hline Relação com os alunos & $\begin{array}{c}\text { Marcada pelo respeito e } \\
\text { autoridade }\end{array}$ & $\begin{array}{c}\text { Marcada pela segurança e } \\
\text { afetividade }\end{array}$ \\
\hline $\begin{array}{l}\text { Aula interessante com o } \\
\text { objetivo do foco do aluno }\end{array}$ & $\begin{array}{c}\text { Ênfase em jogos, interações, } \\
\text { dinâmicas. } \\
\text { Relatos que trazem a } \\
\text { dificuldade dos alunos em } \\
\text { participarem das aulas. }\end{array}$ & $\begin{array}{c}\text { Ênfase em aulas } \\
\text { experimentais/práticas }\end{array}$ \\
\hline $\begin{array}{c}\text { Entendimento sobre a } \\
\text { relação professor-aluno } \\
\text { para o aprendizado } \\
\text { acontecer }\end{array}$ & $\begin{array}{l}\text { Importante, porém, difícil de } \\
\text { conseguir }\end{array}$ & $\begin{array}{c}\text { Relação transferencial - } \\
\text { (Afetiva por ambos os lados) }\end{array}$ \\
\hline
\end{tabular}

Ao longo das entrevistas, houve alguns destaques nas respostas dos alunos e professores entrevistados. Nas entrevistas com os 21 alunos das escolas A e B, notou-se uma dificuldade maior, em 14 alunos, para responder sobre as características e a relação com os professores de que mais gostam. Inicialmente respondiam que gostavam de todos ou que todos eram "legais". Quando solicitados que falassem mais sobre a relação com os professores, de uma forma geral foi possível observar a distinção dos que mais gostavam com mais detalhes. Entre os 10 alunos da escola C, houve facilidade para falar das características dos professores de que mais gostavam, porém não conseguiram inicialmente detalhar sobre a relação. Quando perguntados sobre a relação no geral com todos os professores, conseguiram falar mais sobre os professores de que mais gostavam. Os 17 alunos da escola D não tiveram dificuldades iniciais em nenhuma das perguntas. Destaca-se esta escola pela diversidade de práticas artísticas na grade curricular e por todos os alunos entrevistados mencionarem, em algum momento da entrevista, sobre essas aulas e seus benefícios, nos modos de falar, na expressão e em como os ajudaram a vencer a timidez.

Três professoras da escola A emocionaram-se ao responder sobre o que é ser professora. Uma delas estava prestes a se aposentar e chorou ao ser perguntada 
como se sentia em sala de aula. Ela respondeu que se sentia "péssima”. Três professoras da escola B, oriundas de escolas particulares, demonstraram, em suas respostas, estar igualmente atentas à de seus alunos do ensino público. Ainda afirmaram que a aula oferecida é a mesma ministrada aos estudantes da escola particular onde atuaram. Enfatizam que não podem exigir menos destes alunos com a justificativa de serem estudantes da rede pública de ensino público e, que muitas vezes, não têm acesso à estrutura material oferecida pela instituição privada. Essas professoras não deixaram de mencionar algumas das discrepâncias que observam: a falta de material para o uso em aulas; a ausência de políticas públicas que incentivem a qualificação e a melhor condição de trabalho; o cotidiano dos alunos que em sua maioria estão expostos a situações de vulnerabilidade, o que muitas vezes os afastam da escola. O número total de entrevistas nessas escolas foi 12. O sentimento de troca afetiva, vínculo e a importância de perceberem o aluno no seu cotidiano marcaram as entrevistas realizadas com os 11 professores das escolas particulares C e D.

$\mathrm{Na}$ escola $\mathrm{C}$, as entrevistas com os professores foram marcadas pelo encantamento e idealização com a pergunta sobre o que é ser professor. Todos os seis entrevistados dessa escola falaram como iniciaram a carreira pedagógica e o que pensaram na época, e como veem a profissão depois de alguns anos de formados.

Na escola D, o destaque foi a percepção dos professores em relação à fala articulada dos alunos. A justificativa foi a de que essa escola oferece vários tipos de aulas de artes em sua grade curricular, diferenciando-a de outras escolas. O entusiasmo dos cinco professores entrevistados foi também notável nas entrevistas ao falarem da importância do vínculo com os alunos para o aprendizado.

\section{2}

\section{Escala do Clima Escolar - QCE-EF}

Os alunos que participaram das entrevistas foram submetidos a responder à escala de clima escolar, QCE-EF, um questionário de autorrelato de 37 itens que busca medir a percepção dos estudantes sobre o clima de sua escola. Os respondentes são solicitados a indicar, em uma escala de três pontos, o grau com que eles concordam com vários itens que compõem o clima da escola. 
Para a correção do questionário, os itens formulados negativamente (1, 6, $9,12,1$

4, 20, 21, 23, 24, 33) devem ser invertidos e, em seguida, somados com os demais itens. Desse modo, quanto maior a pontuação total do participante no questionário, maior o grau de percepção dos estudantes acerca da qualidade do clima escolar. Além disso, é possível avaliar cada uma das seis dimensões do ambiente escolar que são avaliadas pelo QCE-EF. Isto pode ser obtido através da soma da pontuação dos itens que definem a dimensão e da divisão desta soma pelo número de itens que compõem a referida dimensão, conforme tabela abaixo. Os itens formulados negativamente e citados acima devem ser sempre invertidos.

Tabela 4: Questionário de Clima Escolar - Versão Revisada Ensino Fundamental (QCEEF).

\begin{tabular}{|c|c|}
\hline DIMENSÕES & ITENS \\
\hline $\begin{array}{ccccc}\text { Justiça } & \text { (igualdade de tratamento entre } & \text { os } & \text { alunos, } \\
\text { independentemente da etnia e status socioeconômico) } & & \end{array}$ & $3,7,13,31,32$ \\
\hline $\begin{array}{l}\text { Ordem e disciplina (adequação do comportamento dos alunos } \\
\text { no ambiente escolar) }\end{array}$ & $\begin{array}{l}1,6,9,18,20,24 \\
33\end{array}$ \\
\hline $\begin{array}{l}\text { Envolvimento dos pais (frequência de participação dos pais nas } \\
\text { atividades escolares) }\end{array}$ & $4,8,27,29,36$ \\
\hline $\begin{array}{l}\text { Troca de recursos (oportunidades iguais para os estudantes } \\
\text { participarem das atividades escolares e utilizarem materiais e } \\
\text { equipamentos) }\end{array}$ & $12,14,21,23$ \\
\hline $\begin{array}{l}\text { Relações interpessoais dos alunos (os níveis de cuidado, } \\
\text { respeito e confiança que existe entre os alunos da escola) }\end{array}$ & $\begin{array}{c}2,5,15,16,22,25 \\
34\end{array}$ \\
\hline $\begin{array}{l}\text { Relação aluno-professor (o nível de cuidado, respeito e } \\
\text { confiança que existe entre alunos e professores na escola) }\end{array}$ & $\begin{array}{l}10,11,17,19,26 \\
28,30,35,37\end{array}$ \\
\hline
\end{tabular}

A partir dos dados obtidos na escala com os alunos, foi possível chegar ao resultado descritos na tabela a seguir. Foi realizado o somatório de todos os alunos por itens de cada escola. Para calcular a pontuação máxima, foi realizado o somatório hipotético da numeração máxima e multiplicado pelo número de alunos participantes. Para o alcance da numeração (decimal) entre os parênteses, foi multiplicado o resultado por dez e dividido pela pontuação máxima que poderia ter sido alcançada. 
Tabela 5: Resultados do questionário de clima escolar - Versão Revisada Ensino Fundamental (QCE-EF).

\begin{tabular}{|c|c|c|}
\hline DIMENSÕES & $\begin{array}{c}\text { ESCOLA } \\
\text { PARTICULAR }\end{array}$ & $\begin{array}{l}\text { ESCOLA } \\
\text { PÚBLICA }\end{array}$ \\
\hline $\begin{array}{l}\text { Justiça (igualdade de tratamento entre } \\
\text { os alunos, independentemente da etnia e status } \\
\text { socioeconômico) - máximo }=405 \text { e } 315\end{array}$ & $\begin{array}{l}399 \\
(9,8)\end{array}$ & $\begin{array}{c}268 \\
(8,5)\end{array}$ \\
\hline $\begin{array}{l}\text { Ordem e disciplina (adequação do } \\
\text { comportamento dos alunos no ambiente escolar) } \\
\text { - máximo }=567 \text { e } 441\end{array}$ & $\begin{array}{l}439 \\
(7,7)\end{array}$ & $\begin{array}{l}306 \\
(6,9)\end{array}$ \\
\hline $\begin{array}{l}\text { Envolvimento dos pais (frequência de } \\
\text { participação dos pais nas atividades escolares) - } \\
\text { máximo= } 405 \text { e } 315\end{array}$ & $\begin{array}{l}300 \\
(7,4)\end{array}$ & $\begin{array}{l}199 \\
(6,3)\end{array}$ \\
\hline $\begin{array}{l}\text { Troca de recursos (oportunidades } \\
\text { iguais para os estudantes participarem das } \\
\text { atividades escolares e utilizarem materiais e } \\
\text { equipamentos) - máximo }=327 \text { e } 252\end{array}$ & $\begin{array}{l}262 \\
(8,0)\end{array}$ & $\begin{array}{l}213 \\
(6,0)\end{array}$ \\
\hline $\begin{array}{l}\text { Relações interpessoais dos alunos (os } \\
\text { níveis de cuidado, respeito e confiança que } \\
\text { existe entre os alunos da escola) - máximo= } \\
567 \text { e } 441\end{array}$ & $\begin{array}{l}478 \\
(8,4)\end{array}$ & $\begin{array}{l}283 \\
(6,4)\end{array}$ \\
\hline $\begin{array}{l}\text { Relação aluno-professor (o nível de } \\
\text { cuidado, respeito e confiança que existe entre } \\
\text { alunos e professores na escola) - máximo }=729 \\
\text { e } 567\end{array}$ & $\begin{array}{l}697 \\
(9,5)\end{array}$ & $\begin{array}{l}483 \\
(8,5)\end{array}$ \\
\hline
\end{tabular}

Os alunos não tiveram dificuldades para responder a maioria das perguntas. Observou-se através dos resultados que os itens como justiça, relação aluno-professor, relações interpessoais dos alunos e troca de recursos obtiveram maiores pontuações nas escolas particulares. Já nas escolas públicas, a justiça e a relação professor-aluno foram as pontuações maiores.

A diferença de uma escola para outra no item troca de recursos foi notável nos contextos pesquisados. A Arte foi um campo de destaque no estudo sobre as escolas. O material da sala de artes da escola D se mostrou farto, com tintas, cartolinas e colas coloridas visíveis. Na escola B, havia cartolinas e um mural com trabalhos realizados pelos alunos com papel colorido. Contudo, nas entrevistas, houve em certos momentos a frustração por parte dos professores das escolas públicas por não ter material disponível. As práticas artísticas são diversas na escola D, como teatro, música, canto (possuem uma sala com instrumentos); na escola C, eram menos significativas as práticas artísticas, porém com uma diversidade maior do que nas escolas públicas. Nas escolas A e B, existe a aula de artes plásticas em que são abordados desenhos, colagens e técnicas de pintura. Esses dados foram obtidos pelas entrevistas com as professoras de Arte, duas professoras da escola A uma da escola B e uma da escola C. 


\section{3}

\section{Discussão dos Resultados}

\subsection{1}

\section{O papel da afetividade nos processos de aprendizagem}

Entender a afetividade e perceber como os sujeitos são influenciados de maneira positiva ou negativa nos processos de aprendizagem escolar era o principal objetivo deste trabalho. A afetividade foi um ponto constante na fala dos professores trazendo para essa pesquisa um alinhamento da teoria com a prática. Verdadeiramente desde a mais tenra idade, o ser humano demonstra preferências e rejeições. Como ressalta Wallon (1968), o bebê já demonstra afetividade no contato com seus cuidadores, com olhares, sons e alterações de comportamento e movimentos corporais. À medida que a criança desenvolve a parte motora, a cognitiva e a afetiva, elas passam atuar juntas, em prol do seu desenvolvimento integral. Vygotsky (1984) sublinha o convívio social e a importância da percepção do adulto com a criança em relação a essa interação, mas tanto ele como Wallon (1968) falam sobre o ambiente em que a criança está inserida não como um fator determinante para o seu desenvolvimento e, sim, como um influenciador nas diferentes relações que se estabelecem entre a criança, os variados agentes de seu cotidiano e o meio onde estas relações acontecem, como a casa, os locais de lazer e a escola.

Reiterando o que foi dito no capítulo anterior, Dayrell (1996) situa a escola como um local de relações diversas podendo assim ser um lugar de expansão da expressão e dos afetos entre os sujeitos que ali estão. Os professores entrevistados também parecem compreender a afetividade como um elemento essencial para a relação professor-aluno e sua influência no aprendizado, como vemos nos depoimentos a seguir:

(...) é muita tranquila (a relação com os alunos), de diálogo, de afeto, de conhecimento profissional, mas também de um pouco de intimidade, gosto de abraçar, gosto de beijar (Professora de Português e Redação, $9^{\circ}$ ano, escola C, leciona há mais de cinco anos). 
Fundamental (na relação) é o primeiro, o da afetividade, porque quando você estabelece essa relação, você ganha o aluno. Se você não ouve o aluno, ele não se sentirá à vontade de chegar até você. Ele também nunca terá a questão da aprendizagem resolvida, porque a partir do ponto em que ele tiver dúvida, ele não encontrará um canal possível. Então, para mim, a afetividade, a relação professor-aluno passa pelo afeto sempre (Professora de matemática, $9^{\circ}$ ano, escola C, leciona há 20 anos).

Na mesma direção, uma aluna diz:

Eu acho que um bom professor tem que saber dar aula para que os alunos fiquem prestando atenção com prazer e tem que ser tipo um professor que tenha um afeto com os alunos e que ouça os alunos. Na maioria das vezes, que seja amigo dos alunos (Aluna do $7^{\circ}$ ano da escola D).

Aqui a participante destaca a importância da escuta, de uma relação que toma o diálogo como princípio, assim como a professora. Freire (1987, p. 45) explica sobre o papel da fala enquanto sujeito no mundo, existindo, atuando. O diálogo tem uma função de marcar ideias, opiniões, trocas, é uma ação de existência. As relações de confiança e de afeto acontecem também pelo diálogo, pela pronúncia de algo que necessita ser falado e entendido pelo outro.

Notou-se, pelas entrevistas, que a palavra afeto surgiu nos depoimentos professores por seis vezes. Uma dessas falas é a da professora de matemática da escola C que utilizou o afeto para responder à questão sobre o que é ser um bom professor. Esta fala evidencia que os professores reconhecem a importância de se construir um canal de confiança e de troca com seus alunos, e que, muitas vezes, estão buscando esse caminho, o que nem sempre é possível, até pela dificuldade que muitos alunos têm com sua matéria, o que, em alguns casos, gera antipatia e resistência ao professor. A palavra afetividade surgiu três vezes na entrevista com duas professoras da escola pública e uma vez na fala de uma professora da escola C. Já com as professoras de português e de inglês, das escolas A e B, a questão era sobre ser um bom professor e como era o sentimento em sala de aula. A relevância da afetividade na relação com o aluno veio como consequência na fala da professora:

Passou o tempo em era só transmitir um determinado tipo de conhecimento. (O trabalho) envolve muitas outras tarefas, envolve afetividade, comprometimento, muitas vezes você faz a parte que 
cabia à família e não cabe mais, e a realidade que a gente acaba percebendo de muitas crianças é essa, a gente acaba fazendo muito a parte dos pais, (ser professor) envolve muito mais que a sua disciplina em si (Professora de Inglês, $7^{\circ}$, escola A, leciona há mais de 10 anos).

A professora da escola B menciona a relação de afeto com os alunos, ao responder como ela se sente em sala de aula:

É cansativo, mas é prazeroso. É muito bom, eu me sinto realizada. Por mais que a minha visão de magistério tenha se quebrado nesse cotidiano, outras questões vieram na relação com eles, a afetividade é... você percebe como eu falo, né? O progresso deles, por exemplo (Professora de Português, $7^{\circ}$, escola B, leciona há 24 anos).

Dentro da teoria walloniana, Galvão (1995) menciona o impacto da afetividade no processo cognitivo, alertando para os sinais expressos pelo sujeito. Os afetos são demonstrados muito cedo; as emoções vêm pelo bebê em momentos alternados de calma e carinho / gritos e esperneio por alguma dificuldade. Nessa fase tudo está se iniciando. Na infância, a parte motora está em franco desenvolvimento, o sujeito demonstra seus afetos com destaque para os gestos, o andar, a demonstração de interesse em pegar os objetos ao redor. No processo em que a criança está formando a sua personalidade, as expressões de afeto acontecem a partir das interações que ela faz com as pessoas que estão ao seu redor, além de seus cuidadores. Portanto as expressões são expandidas pela diversidade. Os afetos estão presentes na linguagem, gestos e apreciações que a criança faz no seu meio.

Com os alunos, a palavra afeto surgiu com dois entrevistados, das escolas A e $\mathrm{D}$, do $9^{\circ}$ ano. Os alunos trazem o vocábulo para diferenciar o professor de que mais gostavam e o porquê. Mesmo sem mencionar o termo, é possível observar o lugar da afetividade nos discursos dos alunos:

(...) eu tenho admiração por ela, (sic) eu acho ela uma professora magnífica. Ela é de Português e faz umas analogias com a literatura e com tudo o que a gente está estudando, e com a realidade que eu acho muito maneira, sabe? E o de Ciências tem dado umas lições assim para a gente. Tem a L. que também eu gosto, não tem “aquele” afeto, mas eu gosto dela. Ela também fala bastante coisa do que está acontecendo e tal. Ela cobra muito da gente de falar na aula tipo, essa turma, a maioria das pessoas não gosta de falar muito na aula e eu sou uma das pessoas que falam bastante. (Aluna do $9^{\circ}$ ano, escola D). 
O aluno da escola A, do $9^{\circ}$ ano, explica por que gosta mais de uma determinada professora:

Ela sempre me pergunta como eu estou, me faz eu me sentir bem comigo mesmo, ela se preocupa comigo, quando eu estou triste, ela pergunta: "Você está bem? ”.

O evento destacado acima mostra como o afeto pelo professor é construído a partir de uma relação com o conhecimento, com a proposta educativa apresentada em sala, na pertinência dos conteúdos, na sua relação com o mundo. Freire (1997) cria um jogo de palavras entre "ensinado” (o aprendiz) e “ensinante” (aquele que ensina). Antes de ser professor, o “ensinante” já foi aluno e lembrarse disso ajuda-o a reconstituir esse processo, a lembrança pode trazer também a humildade necessária em sala de aula para manter o vínculo com o aluno. Ter alguém que já passou pela experiência do aprendizado pode ser muito frutífero se essa pessoa estiver aberta a proporcionar aos alunos caminhos para a curiosidade, o despertar e o olhar crítico e questionador, tão necessários nesse processo.

Outro aspecto a ser destacado, que emerge das entrevistas, é o reconhecimento dos professores de que é preciso gostar da docência para afetar seus alunos positivamente em suas experiências de aprendizagem.

Eu aтo o que eu faço, eu amo o que faço. Eu simplesmente adoro o que eu faço (a professora ficou emocionada nesse momento). Poder trabalhar com arte e ensinar, mostrar o que é e poder despertar neles o desejo de apreciação, e como a arte está inserida no dia a dia deles. Para mim, a sala de aula é o meu palco, o meu habitat, eu adoro estar (lá) falando, eu adoro (Professora de design, $9^{\circ}$ ano, escola $C$, leciona há 8 anos).

Dentro da mesma discussão, outra professora enfatiza o compromisso político, a formação crítica como responsabilidade da educação. Contudo, ao falar desse processo, o professor utiliza o termo “moldadas”, o que traz uma certa dúvida sobre a concepção de ensino assumida.

É um grande desafio, porque a gente participa, na verdade, da formação como cidadãos, (sic) estimulando eles a serem pessoas críticas, moldadas de alguns valores, entendeu? Então é um grande desafio (Professor de Educação Física, $7^{\circ}$ e $9^{\circ}$ ano, escola, C, leciona há 12 anos).

Diferentemente das realidades das escolas particulares pesquisadas, nos contextos públicos, o discurso dos professores vai numa outra direção. Quando 
perguntados sobre a relação com alunos e como se sentem em sala de aula, muitos trazem uma avaliação bastante negativa.

Péssima. Porque a minha clientela.... A maioria não tem interesse em aprender, a maioria não respeita a figura do professor, você entra na sala e parece que ninguém está na sala. E o que deixa a gente mais angustiada é essa falta de interesse em aprender, essa falta de vontade de receber aquilo que temos para dar para eles (Professora de Matemática, $7^{\circ}$ ano, escola, B, leciona há mais de 25 anos, prestes a se aposentar).

A partir da leitura do trecho em destaque é possível observar que uma grande dificuldade encontrada é o desinteresse dos alunos, a falta de respeito pela figura do professor. Mediante as diversas maneiras de alcançar o conhecimento, o professor pode se tornar uma figura apagada se não tiver estabelecido um vínculo com seus alunos. Castro (1998) traz a questão dos meios de comunicação, que podem distanciar ainda mais o professor de seu papel de "fonte de conhecimento" para os estudantes. O aprendiz hoje não é mais alguém que apensar está disposto a receber, mas ele também quer trocar, interagir, opinar e debater, o que só é possível quando há, no professor, uma disponibilidade para receber e se renovar. A facilidade de se ter uma informação hoje compete de alguma maneira com uma aula que não tenha algo que desperte a atenção dos alunos. A necessidade de buscar novos suportes, preparar aulas relacionadas com o cotidiano do aluno e, principalmente, querer estar em sala de aula, faz-se obrigatória.

Ademais, a falta do reconhecimento pelo trabalho desenvolvido torna-se uma barreira para o professor. Arroyo (2001) aborda a questão da "indefinição profissional” associada à imagem social que é construída do professor. A indefinição vem quando não se sabe o que fazer em sala de aula, quando não há mais motivação e os alunos são vistos e sentidos como um peso. Dessa forma, imagens são construídas: "sem paciência”, “não gosta do que faz”, “está aqui por obrigação”, e a repercussão dessas expressões, vinda dos alunos, torna-se a imagem criada do professor, principalmente, nas escolas públicas. O mais grave é quando essa imagem é generalizada, inclusive, entre o próprio corpo docente.

O reconhecimento dos alunos como parceiros na prática docente traz o envolvimento com a profissão, da relação professor-aluno ser pautada na amorosidade, na humildade, na compreensão das experiências dos que estão presentes na sala de aula (FREIRE, 1987). 
Ah, eu sou uma pessoa muita tímida, mas eu tenho dois lugares em que eu me sinto bem - no palco, eu durante muito tempo atuei e até 2006, eu tinha um grupo de teatro; e na sala de aula. Aqui é o meu espaço, eu me sinto, né? Eles me alimentam, todas as dificuldades que o ambiente público tem, os alunos são mais difíceis. Eles têm uma dificuldade maior de expressar carinho, de se deixar ser afetados. Eles são defensivos, mas acho que uma hora a gente consegue um acesso. E esse acesso vem também de você se mostrar humano, de se mostrar frágil, em alguns momentos. Por isso que eu digo que é uma relação de amor, profundamente carinhosa, de muita troca. É um exercício de generosidade (Professora de Artes, $7^{\circ}$ e $9^{\circ}$ ano, escola, $B$, leciona há 25 anos).

As experiências discentes, nos diferentes contextos, trazem uma sintonia com os alunos de realidades díspares, eles têm um olhar positivo sobre a escola, associando a escola a uma segunda casa, muitos preferem ficar na escola do que em casa, afirmam o sentimento de conforto e acolhimento experimentado na escola. Ainda destacam:

Ah, eu me sinto, sei lá, na sala de aula, eu me sinto segura, mas quando eu estou no recreio eu me sinto outra pessoa porque muitas pessoas ficam olhando e são grandes. E sei lá, rola briga e conflitos e eu tenho medo que isso aconteça comigo. Aí eu me sinto insegura, às vezes (Aluna do $7^{\circ}$ ano, escola B).

Eu me sinto muito acolhida porque, tipo assim, eu entrei no $5^{\circ}$ ano $e$ eu estava com muito medo da escola só que eles me acolheram superbem. E na primeira semana de aula, já fiz amizade, já conversava com as pessoas, já tinha intimidade com a professora. Eu brincava sempre no recreio com as pessoas que eu tinha mais intimidade. E tipo assim, a minha turma eu amo muito todos eles, só que claramente tem pessoas que eu sempre vou ter mais intimidade (Aluna do $7^{\circ}$ ano, escola D).

Eu adoro essa escola. E eu adoro essa relação que ela tem com as artes. Acho muito importante porque a arte ajuda a entender o que está sendo dado dentro da sala. Eu sempre estudei aqui, saí por 3 anos e voltei. Cada escola tem um jeito de ensinar e você vai criando os modos de relação e dá para ver que existe diferença nas escolas (Aluna do $7^{\circ}$ ano, escola, D).

Dayrell (1996) explica sobre o espaço escolar ser um lugar de encontros de diversidade, de construção de amizades, relacionamentos, conflitos e brigas. 
Dessa forma, a possibilidade de conseguir transformar e compreender melhor os alunos se torna abrangente se o real papel da escola for acolher a diversidade que se faz presente. Encontrar maneiras de dar espaço aos alunos para se colocarem é um caminho de compreensão. Para alguns, a arte pode ter um papel facilitador da expressão no aprendizado.

De acordo com as entrevistas, a escola tem um sentido único na vida dos alunos. Palavras como "segurança" e "afeto" surgiram em vários momentos do diálogo com os estudantes: "Eu estudava em outra escola. Eu acho que aqui eu me sinto mais livre para falar, tanto que tem o espaço para falar, sabe? ” (Aluna, $9^{\circ}$ ano, escola D); "Como eu estou aqui desde pequena, eu sinto uma conexão maior, me sinto mais ligada à escola” (Aluna, $9^{\circ}$ ano, escola D); “Eu gosto de vir para a escola. É uma segunda casa. Me sinto seguro aqui" (Aluno, $9^{\circ}$ ano, escola, $B)$.

Entretanto, nem todos os alunos têm a mesma vivência - Sozinho, eu não tenho amigos (Aluno, $7^{\circ}$ ano, escola, B). Como discute Isaia (1998), a escola tem papel fundamental na vida dos alunos, como mediadora das relações, marca os relacionamentos e ajuda na construção da autoimagem. A escola tem grande interferência no desenvolvimento das crianças e dos adolescentes.

\footnotetext{
Eu me sinto muito bem aqui na escola, eu me sinto bem confortável, é um ambiente acolhedor. Eu posso me expressar, tirar dúvidas e eu sei que serei bem recebido sempre e eu realmente sinto que a palavra certa para essa escola é um conforto que sinto aqui, um lugar que eu tenho certeza que se eu tiver aqui vai estar tudo certo, que eu posso fazer as coisas sem medo, sabe? (Aluno do $9^{\circ}$ ano, escolas, $D$ ).
}

\subsection{2}

\section{O que cada um vê da janela: modos de interação na escola}

Para falar das características da interação professor- aluno, existe uma necessidade de olhar para a construção de cada sujeito dessa relação. Estar atento ao crescimento com um viés de cuidado é um caminho para se pensar na infância. Arroyo (2001) traz a infância como um "vir a ser” e não como algo naturalizado dentro de padrões. As imagens construídas na escola se apoiam no que se entende por aluno e pelo que é ser professor. Para Arroyo (2001, p.40) "as crianças têm o dever de ser e os educadores, o dever de dar conta de que sejam”. 
Os alunos quando perguntados sobre com quem mais se identificavam/gostavam, mencionaram o professor que tem interesse por suas vidas particulares, igualmente quando perguntados o que, para, seria "um bom professor”. Relataram ainda o quanto gostavam quando a matéria ministrada tinha relação com o cotidiano de cada um:

"Eu acho que você tem que ensinar bem e dar exemplos reais do cotidiano e você tem que discutir todo o pensamento crítico. Você não pode fazer uma coisa padronizada” (Aluna 1 do $7^{\circ}$ ano, escola D).

“A professora de Português fez uma colagem sobre a janela da casa de cada um- o que cada um vê da janela, e aí foi muito legal, e a gente ficou várias aulas fazendo isso " (Aluna 2 do $7^{\circ}$ ano, escola $\left.D\right)$.

Arroyo (2001, p.231) reforça a ideia de que os educadores precisam estar realmente atentos aos alunos (como individualidades), porque, além de transmissores de matéria curricular e, portanto, de terem o desafio permanente de criar novas práticas e atividades para dinamizar seu cotidiano em sala de aula em torno do conteúdo teórico e técnico, o professor deve buscar se especializar no que ele chama de "artes de lidar com as pessoas", independentemente das mudanças socioculturais e políticas.

“Um bom professor é aquele que ajuda os alunos, se importa com os alunos, ajuda a ter preocupação com os alunos e ajuda com as coisas ” (Aluno do $7^{\circ}$, escola A).

Como lembra o autor acima mencionado, a escola é uma experiência humana bem mais complexa do que a visão pragmática por vezes imposta. Dos professores é cobrada uma postura bem mais plural do que a de um reservatório de conteúdo técnico. Os tempos de escola são aproveitados por crianças e adolescentes, em sua totalidade, e isto inclui a riqueza que um "encontro de gerações” pode lhes proporcionar (ARROYO, p. 232).

(...) ela fala com a gente sobre a adolescência, sobre essas coisas que acontecem com a gente, esses negócios, e também a professora de História também se abre com a gente. Porque, tipo assim, quando ela vê alguém estranho, ela percebe quando a gente está diferente (Aluno do $9^{\circ}$ ano, escola B). 
Também afirmam que o professor que demonstra entusiasmo no ensino é aberto às críticas, mostra-se flexível, disponível a ajudar.

(...) eles explicam com mais vontade, estão abertos a questionamentos e não estão a presos somente ao material do livro didático (Aluno $9^{\circ}$ ano, escola, $D)$.

(...) porque (sic) eu acho eles divertidos, eles ensinam a gente brincando, ajudando (Aluna do $7^{\circ}$ ano, escola, B).

Como contraponto dos relatos que trazem a relação professor-aluno numa perspectiva positiva, um aluno do $7^{\circ}$ ano, da escola C, fala da ausência de troca em aula entre o educador e o educando: As aulas são mais práticas e normalmente são as que eu menos gosto. (A pesquisadora pergunta o que significa aulas mais práticas na visão dele). Você copia do quadro, não tem tanta interação.

Esse envolvimento com os alunos também emerge das entrevistas com os professores. Em especial, uma professora de Português e Redação do $9^{\circ}$ ano, da escola C, com menos de dez anos de prática docente, demonstrou uma implicação marcante com suas turmas:

A relação professor-aluno no processo ensino-aprendizagem sempre tem que levar em conta primeiro o aluno. Então, o professor tem a sua personalidade, a sua formação, e é claro que isso vai ser respeitado, mas ele precisa entender o aluno, não no sentido de tudo o que ele quer, mas no sentido de perceber quais são as necessidades do aluno. $O$ ensino precisa ser voltado para a aprendizagem, o objetivo do ensino é a aprendizagem. Então, a relação do alunoprofessor tem que ser algo que privilegie o aluno, como ele está entendendo. Então, o professor é um profissional sempre em construção, o que ele pode fazer e o que ele não pode fazer, não é para estar escravo do aluno ou se o aluno acha legal ou não, mas é porque ele está à mercê da aprendizagem do aluno e isso é importante (Professora de Português e Redação, $9^{\circ}$ ano, escola, C, leciona há mais e cinco anos.).

Diante desse fragmento, é possível observar que essa professora considera o aluno como centro irradiador do processo pedagógico, sendo essencial valorizar os conhecimentos e culturas das crianças e adolescentes, tomando seus interesses e curiosidades como elementos disparadores da organização do trabalho pedagógico. Na mesma direção, Freire (1997) fala sobre a espontaneidade em sala 
de aula e confirma dessa forma, a relação fluida com o aprendizado tanto de quem ensina quanto de quem aprende. Ele destaca ainda o compromisso da escola com o ensino e a aprendizagem, sem perder de vistas os sujeitos, professores e alunos, em suas singularidades. É muito interessante observar que o fato de a professora reconhecer e considerar os estudantes no processo educativo não significa que abrirá mão do seu lugar de autoridade, da responsabilidade docente com a formação dos seus alunos.

Dialogando com essa questão, um professor afirma:

(...) o vínculo pelo afeto é muito importante na relação com os alunos. O afeto, a confiança, o desejo. Acho que passa por isso também, pela relação de confiança e o desejo de saber, de conhecer, também vão vir dessa relação. A escola também tem uma relação muito próxima com os alunos, até mesmo por ser pequena, e isso é muito presente aqui. E isso é muito bacana, esse tempo com os alunos fez de mim uma pessoa melhor, sabe? Me deixou mais atento para as atitudes específicas de cada aluno, para entender melhor cada aluno e cada dificuldade e tentar chegar em cada aluno. Isso foi uma coisa nova para mim, acho que eu tinha uma relação mais distante e hoje eu percebo que tenho uma relação mais próxima com eles, e isso é importante. Acho que ser pai também ajudou a esse entendimento (Professor de História, $9^{\circ}$ ano, escola D, leciona há 15 anos).

Além de enfatizar a relação com os alunos como espaço de troca, de afeto, de aprendizagens, fala do seu movimento de busca por uma aproximação, de rompimento com a imagem do professor como autoritário, distante e indiferente, que transmite os conhecimentos sem convidar os educandos à reflexão. Ele aponta para uma prática problematizadora, reconhecendo a importância da escola na construção dessa cultura, pensando a educação numa esfera coletiva - E $a$ escola tem também uma relação muito próxima (...). Vale destacar que o professor compreende que a paternidade qualifica sua experiência como educador.

Em outra entrevista, outra profissional comenta:

Aquele menino que acabou de sair é ex-aluno, ele veio aqui para me visitar. É uma coisa assim de muita troca, da gente se dar muito bem fora da sala de aula também, não é só dentro. Mas eles percebem o momento que eu sou professora e o momento que vou dar carinho, que vou ouvir os problemas, que vou fazer piada também. Então, eles percebem, e eu demonstro de uma forma clara para eles, na idade deles isso se perde, os limites. Mas eu acho que a relação que eu 
tenho com eles é uma relação muito boa de troca dos dois lados, eu saio ganhando muito com isso (Professora de Artes Plásticas, $7^{\circ}$ e $9^{\circ}$ ano, escola B, leciona há mais de 25 anos).

O fragmento acima destaca, mais uma vez, a valorização dos alunos, reconhecendo a relação entre professor e aluno como espaço de interação, de aprendizagem mútua - como diz Freire (1987, p. 69): “Já agora ninguém educa ninguém, como tampouco ninguém se educa a si mesmo: os homens se educam em comunhão, mediatizados pelo mundo”. No entanto, a professora revela uma contradição. Ao mesmo tempo que reconhece a dimensão relacional e dialógica da experiência do aprender, ela parece identificar a docência com uma função autoritária, onde brincadeira e fluidez têm limite. Esta ambivalência traz uma dicotomia entre educador e educando.

Sobre o lugar da hierarquização na relação professor-aluno, uma docente parece ter um posicionamento mais flexível, em que o diálogo prevalece:

(...) não sou o tipo de professora que entra em sala de aula e pronto e acabou. Nunca consegui, já tentei. Já tive problema por ser assim, mas eu não consigo. Tem uma hora que eu amoleço, não adianta. Então, na sala de aula, eu e meus alunos somos muito do diálogo, dentro e fora de sala. Então, se um aluno me procura fora da sala de aula, eu acredito que isso é um sinal muito bom. Eu gosto, eu me comprometo, o meu diálogo é dentro e fora de sala de aula (Professora de Português e Redação, $9^{\circ}$ ano, escola C, leciona há mais de cinco anos).

Se por um lado a professora fala da importância do diálogo entre educadores e educandos, demonstrando um sentimento de trabalho bem-sucedido quando é reconhecida como uma referência pelos estudantes; por outro, ela relata que já tentou modificar a sua postura, tomando a sua abertura em relação aos alunos como uma característica negativa. Aqui observa-se uma ambivalência, uma tensão entre uma prática dialógica, que busca construir o trabalho educativo a partir da escuta e da sensibilidade, e uma prática docente que é monológica, distante, sendo o professor aquele que transmite apenas o conteúdo.

A professora de Português, Literatura e Redação do $9^{\circ}$ ano, da escola C que leciona há menos de cinco anos, também destaca a importância de um olhar para as necessidades singulares dos alunos, não apenas para o coletivo - (...) vai influenciar na relação, principalmente para eu ver também como ele está, quais são as dificuldades, eu preciso estar atenta, eu não posso só olhar a turma assim 
no geral, é olhar cada um, o indivíduo, não é? Arroyo (2001) traz um destaque ao olhar do professor para o aluno em formação, um caso de identificação e espelhamento de suas próprias vivências. Os questionamentos em sala de aula são uma forma de autoquestionamento para o professor.

Outra professora menciona a importância do estabelecimento de limites, da afirmação do professor como autoridade, o que não significa ter um relacionamento distante.

Eu até vi no facebook de uma colega, semana passada, sobre outro colégio que eu trabalhei: um aluno teria repreendido a professora por ela ser amiga dos alunos dela. É lógico que você tem que ter muito (cuidado), porque às vezes o aluno confunde o que é ser amigo e o que é ser professor. Então, você tem que ter autoridade e ter um bom relacionamento, mas não somos (os professores) amigos ou coleguinhas deles. É diferente, mas com todas as turmas que eu tenho esse bom relacionamento, o trabalho corre muito mais tranquilo. $E$ uma coisa também, eu dei aula em outra escola e teve uma estagiária que ficou impressionada com a minha metodologia, que eu evito muito brigar, tirar de sala é o último recurso. Quando acabou o diálogo, eu sempre tento ir para o diálogo, tentar chamar a atenção 1,2, 3 vezes e quantas vezes for necessário. Aí se eu sentir que não está funcionando, aí eu tiro de sala, porque eu acho que você criar esse atrito logo de cara.... Encerrando a aproximação com o aluno, você vai criar uma barreira que às vezes não se desfaz. Então, eu sempre tento partir para esse diálogo, ter uma tolerância, do que tomar uma atitude mais rígida (Professora de Biologia, $7^{\circ}$ e $9^{\circ}$ ano, escola $C$, leciona há mais de cinco anos).

Mesmo com o destaque para o diálogo como um elemento importante da relação professor-aluno, a professora afirma que assume práticas mais autoritárias depois de insistir em outros caminhos. Após o insucesso do diálogo, a educadora parece acreditar que uma decisão rígida ganha legitimidade. Para Freire (1997) a disciplina em sala de aula pode ser construída na relação em sala de aula. Os limites são colocados à medida da clareza da relação e das regras e pela compreensão. O entendimento das partes envolvidas se espelha na construção da relação. A firmeza se torna necessária acompanhada do olhar atencioso para os alunos.

O tema da autoridade foi recorrente nos relatos, como identificamos no próximo fragmento: 
Se você pega um $6^{\circ}$ ano ou $7^{\circ}$ ano, eles não têm resposta pronta para nada. A aula é sempre imprevisível. Tudo o que você faz, o resultado é diferente do que você achou que iria ser. Então, já faz tempo que não me sinto uma autoridade única ali dentro. A bagunça faz parte do processo, sabe? Eu acho que a falação, a interrupção, você vai precisar lidar com isso, isso não é fácil, mas eu me sinto bem, eu me sinto. Toda vez que eu estou com eles, os menorzinhos, eu me sinto crescendo, eu saio muito transformada, eles têm muito a dizer que o adulto não diz e o adolescente mais velho também não diz mais. Semana passada eu fiz uma discussão sobre o dia da mulher com os menores que foi muito mais rica, bonita (Professora de História, $7^{\circ}$ e $9^{\circ}$ ano, escola C, leciona há mais de 10 anos).

Chama muito atenção a frase da professora - já faz tempo que não me sinto a autoridade única ali dentro. Será que a professora traz um certo estranhamento com relações mais horizontais entre alunos e professores? A educadora fala da sua dificuldade em lidar com a bagunça, mas reconhece que faz parte do contexto da sala de aula. A descrição da bagunça como “falação" e “interrupção" traz o questionamento se a participação, as formas de resistência e crítica dos alunos estão sendo tomadas como ameaça à ordem. Será que a professora gosta mais dos "menorzinhos” porque o exercício de controle e do poder pode ser mais fácil com crianças menores?

Se alguns relatos mencionam abertura e disponibilidade dos professores, outros apontam numa direção contrária. Um aluno fala sobre o seu medo em tirar dúvidas: Sei lá, do professor ficar bravo, sei lá, xingar na mente dele que eu sou burro, sei lá, algo assim, vergonha, sei lá ... (Aluno, $9^{\circ}$ ano, escola B). Em outro relato encontramos de novo essa questão:

Eu tiro algumas dúvidas, mas na prova eu não gosto muito de perguntar, se eu pergunto é para a auxiliar que eu pergunto, eu gosto muito delas, só pergunto para o professor se for o caso e se só ele puder me responder" (Aluna, $7^{\circ}$ ano da escola D).

Ainda discutindo a relação professor-aluno, as falas evidenciam que os alunos se sentem confortáveis em sala de aula, o que traz um desdobramento positivo para o processo de aprendizagem - Quando eu preciso tirar dúvidas, eu tiro. Quando é algo que eu saiba, eu dou minha opinião e participo bastante (Aluna, $7^{\circ}$ ano, escola D).

A mesma percepção é observada nos relatos dos alunos: 
Olha, eu assim me sinto livre para falar com eles (com os professores). Eles entendem, sabe? Acho importante, se por exemplo, você tiver um professor chato, você não vai aprender. Um exemplo, minha mãe teve um professor chato do $8^{\circ}$ ano e ela odiava história, até hoje ela odeia história e não sabe o porquê de ter que aprender. E a minha irmã teve uma professora de história - que é até daqui da escola, e ela ama história. Tem tudo a ver (Aluna do $9^{\circ}$ ano, escola D).

Tal aluna também percebe a relação entre afetividade e ensino, trazendo consequências para a trajetória escolar e a vida dos estudantes - gostar ou não de uma disciplina, compreender a articulação do conteúdo com a vida.

Sobre a ideia de uma aula boa, uma professora de História do $7^{\circ}$ e do $9^{\circ}$ ano da escola C afirma: "Não acho que a aula interessante precise de tecnologia, mas a aula interessante é onde os meninos conseguem se sentir contemplados. Se nada daquilo diz respeito à realidade deles, eles não vêm para você" (Professora de História, $7^{\circ}$ e $9^{\circ}$ ano, escola $C$, leciona há mais de 10 anos).

Em outro momento, a mesma professora diz:

(...) teve um dia que eu trouxe o $6^{\circ}$ ano para cá (estávamos na biblioteca da escola). Pedi para fazer uma pesquisa sobre pré-história com os livros e eles não sabem mais pesquisar com o livro, e aí eles ficavam: "Pelo amor de Deus professora, google. O google vai responder tudo”. A atividade não fluía por que eu achei que eles iam conseguir com o livro, mas eu não queria levar para o google. Então, aquela foi uma atividade que não funcionou, não funcionou para pesquisar sobre a história, mas funcionou para conhecer um livro. Aí você tem que mudar o objetivo, você tem que passar a fazer do limão uma limonada, entender que vai ter que lidar com o tempo de outra forma, cada turma tem o seu tempo (Professora de História, da escola C, leciona há mais de 10 anos.).

Para criar um vínculo afetuoso com seus alunos, a professora demonstrou ser flexível, atenciosa e cuidadosa para as necessidades trazidas pelas mudanças socioculturais, porém sem deixar de trocar aprendizados e relativizar as perdas impostas pela resistência da turma à sua proposta.

Ao equilibrar as vantagens e os prejuízos de ceder ao suporte tecnológico em detrimento de sua fonte de pesquisa escolhida, a professora criou um debate sobre as possibilidades e os limites de cada fonte, fazendo, nas palavras dela, do 
limão uma limonada, ou seja, enfatizando, como Freire (1997) o papel da escola como espaço de fomento ao espírito crítico, questionador e criativo.

\subsection{3}

\section{Contextos que afetam e afetividade}

Na relevância da afetividade em sala de aula, uma professora chama atenção para a ausência de consciência dos alunos sobre o estudo, uma falta de clareza das razões da formação escolar. Ou seja, na visão dos alunos, a escola estaria distante da realidade concreta, social “(...) na maioria (dos alunos) eu vejo isso: eles não sabem para que eles vão estudar... Para quê? " (Professora de Matemática, $7^{\circ}$ ano, escola, B). Contudo, ela não analisa criticamente o papel da escola nesse processo de conscientização, apresentando uma proposta educativa que tome os conhecimentos científicos de forma articulada com a vida. Pela fala de uma aluna do $9^{\circ}$ ano, da escola $\mathrm{D}$, foi possível notar a importância do entendimento da razão de se aprender, ao ser questionada sobre o que é ser um bom professor: "Para mim um bom professor é um professor que não faz você decorar, e sim o que faz você saber por que você está aprendendo aquilo e o que vai influenciar na sua vida."

Na escola pública foi perceptível notar como os alunos são marcados pela questão do comportamento, considerados desrespeitosos, mal-educados pelos professores. Alguns pareciam ter uma visão preconceituosa sobre a cultura familiar de alguns alunos, explicando os comportamentos ditos inadequados a partir do cotidiano dos próprios alunos, do modo como viviam e de como eram tratados em casa. Esse modelo explicativo é bastante antigo na escola, uma leitura de que o contexto afeta o desenvolvimento e a aprendizagem dos estudantes.

Mas não se trata de uma consequência unilateral. Nas entrevistas com os professores, emergem nos relatos uma frustração causada pela idealização de uma profissão. Uma professora de matemática há 25 anos, de uma das escolas públicas, que leciona para o $7^{\circ}$ ano, emocionou-se ao falar sobre o que é ser professora:

Professor é a realização de um sonho e....eu sempre tive facilidade para ensinar para os meus colegas e gostava de estudar com colegas que tinham dificuldades. Fui caminhando e cheguei a escolher 
alguma coisa que fosse para ensinar e ser professor para mim é uma missão e emocionante, né? (A professora se emociona nessa hora). A gente não pensa, não dá tempo. Então, quer dizer é aquele dom que a gente recebe de Deus e colocar em prática isso e ser professor é transformar o outro. E se a gente não conseguir fazer isso, a gente não está se realizando profissionalmente. Então, professor para mim é realizar esse sonho e ter como missão.

Aqui a docência aparece como um compromisso com o outro, como possibilidade de transformação, um viés político para a prática profissional, mas também fica evidente uma noção romantizada, tão antiga na história, de que o ofício é uma vocação por dom e uma missão, não uma formação profissional. Arroyo (2001) já apontava este descaminho da profissão.

No entanto, o entusiasmo ao falar das atividades cotidianas não é consenso entre os entrevistados, como é possível observar no fragmento abaixo:

(...)formar um cidadão crítico, consciente e blá, blá, blá, que a gente não está conseguindo, só muito poucos, a gente até consegue, mas em um universo de 30 (alunos), acho que a gente conseguir 5 é muito (Professora de inglês, $7^{\circ}$ e $9^{\circ}$ ano, escola B, leciona há mais de 10 anos).

O fragmento acima revela uma certa desesperança da professora na tarefa de formar cidadãos pensantes autônomos, o que pode ser explicado pelas dificuldades concretas das escolas, especialmente das públicas, com a falta de estrutura, salas de aula lotadas, ausência de apoio e de diálogo entre os professores (ARROYO, 2001).

A falta de condições para a docência também aparece em mais uma entrevista.

É o que a gente mais tem dificuldade de fazer porque isso requer tempo. Estou sendo bem sincera com você, ainda mais na matéria que leciono, para montar uma boa aula tenho que estar em casa, com uma internet ok, procurar vídeo, interligar vídeo com texto, com um conteúdo interdisciplinar. Olha o tempo que isso dá para fazer esses links, esses ganchos e não ser blocos sequenciados. A gente trabalha assim, uma coisa puxa a outra, isso dá outro trabalho para fazer. Um camarada como eu que trabalha em 4 escolas, faz isso como? É complicado, eu poderia fazer muito mais, mas esse ano está difícil para mim, dar conta disso tudo (Professora de Inglês, $7^{\circ}$ ano, escola A, leciona há mais de 10 anos). 
O professor fala dos limites de realizar um trabalho com qualidade ausência de tempo de planejamento e de estudo para o exercício profissional. Além de não ter condições materiais para a realização do seu planejamento.

Na mesma direção, uma educadora fala do cansaço e da ausência de motivação para lecionar com muita força. A sua narrativa impressiona com a desilusão com a profissão, ela não tem o desejo de falar, de expressar seus sentimentos e ideias.

Eu nunca pensei nisso e não quero pensar nisso hoje. Eu esfriei. Assim, enquanto eu estiver e for professora, eu não quero falar, não acredito na educação. Eu não quero porque eu acho que as palavras têm muito poder, mas eu busco acreditar, entendeu. Não... sem ideia (Professora de Português, $7^{\circ}$ ano, escola A, leciona há mais de 25 anos).

As dificuldades com a docência aparecem em diferentes relatos - (...) o $7^{\circ}$ ano é tranquilo, não tenho problema nenhum. Agora o $9^{\circ}$ ano, eles são, essa turma especificamente tem um grupo, que eles são muito cínicos, abusados, parece que estão ali só para afrontar o professor (Professora de Inglês, $7^{\circ}$ e $9^{\circ}$ ano, escola A, leciona há mais de 10 anos).

O contexto social das escolas públicas, ao mesmo tempo que cria estereótipos ao redor do espaço físico, em razão de uma estrutura deficiente, afeta também as relações interpessoais entre alunos, professores e demais agentes escolares. Se as imagens criadas dos alunos são estigmatizantes e a priori já prejudicavam as relações, as entrevistas a esta pesquisa relataram problemas reais e revelaram os sentimentos de desgaste e descrença. O objetivo deste trabalho era analisar os aspectos interacionais nas relações professor-aluno nos processos de aprendizagem. Desta forma, é notável o ciclo vicioso que é criado quando uma das partes não se sente respeitada em sala de aula e a afetividade positiva fica à deriva.

\subsection{4}

\section{A motivação do aluno e contribuições da arte para a aprendizagem}

Há, entretanto, outras formas de se lidar com a realidade que sobrepõe o compromisso profissional à adversidade. Neste contexto, as entrevistas permitiram uma aproximação das realidades públicas e privadas. O fragmento 
selecionado enfatiza a consciência da professora de seu trabalho com os alunos das escolas públicas.

(...)eu brigo muito aqui, não me interessa se ele tem alguma deficiência, alguma ausência ou falta daquilo, eu vou dar sujeito e predicado como eu dou no particular. E não me interessa se ele não tem condições de.... Eu quero o livro do autor tal porque o meu (aluno) da particular tem e o meu da pública não tem. Eu não vejo o meu aluno como um futuro cara que vai trabalhar como caixa de mercado ou ajudante de pedreiro, eu vejo os meus alunos assim como alunos que têm possibilidade de, que tem capacidade de sonhar e em quem eu aposto, se não vai, se vai aprender isso são outros quinhentos, mas o meu papel ou responsabilidade ou a minha consciência é deixar eu aprender com eles como eles são e vamos tentar fazer o melhor para que eles saiam daí com alguma coisa, tá? (Professora de Português, $7^{\circ}$ e 9 $9^{\circ}$, escola B, leciona há 24 anos).

A professora ressalta o direito igual de aprender e ter acesso à mesma aula que tem o seu aluno da escola particular. Esse olhar que inferioriza esses alunos, em sua maioria de um contexto social vulnerável, não é recente na história. A psicologia tem grande contribuição em identificar os mais aptos, entendendo aptidões como naturais, tomando problemas sociais como desajustamento psicológico, de forma descontextualizada da estrutura classista e socioeconômica na realidade brasileira (PATTO, 1997).

O seu relato também sinaliza as diferenças concretas entre os contextos particular e público, com a ausência de recursos nesse último. É interessante destacar que a professora traz uma compreensão de preparação para o futuro, para o mercado de trabalho - vamos tentar fazer o melhor para que eles saiam daí com alguma coisa, tá? Ainda parece distante de uma concepção que toma as crianças e os adolescentes como sujeitos históricos, de direitos, ativos, que agem e interferem no mundo social, predominando uma noção de um "vir a ser”.

Duas professoras ${ }^{8}$ que trabalham nos dois contextos mencionaram as suas propostas de trabalho: projetos de escrita, leitura de textos do interesse dos alunos, a construção de uma caixa de perguntas (os estudantes poderiam depositar suas questões de forma anônima). Observou-se que os professores que dão aulas nas duas redes e que fazem um investimento na sua formação continuada são mais

\footnotetext{
${ }^{8}$ Uma professora de Ciências (leciona há mais de 10 anos) e uma professora de Português (leciona há 24 anos) que foram entrevistadas na escola B.
} 
confiantes em relação à sua prática em sala de aula, o que suscita uma questão: será que a realidade das escolas particulares desses profissionais garante uma formação em serviço de qualidade ou este é um investimento individual?

Diferentemente da primeira professora, que traz uma compreensão da educação como prática social e política, do seu compromisso com os alunos, o relato a seguir evidencia uma visão pessimista:

Eu fiquei muito chateada porque eu vim para a educação com muito idealismo de que eu ia transformar os alunos. E quando você descobre que não é assim, você fica um pouco frustrada. Assim, no fundo é um grande pedantismo, uma grande pretensão a gente achar que realmente isso vai acontecer na nossa aula. Mas ao mesmo tempo eu me sinto feliz (Professor de História, $7^{\circ}$ e $9^{\circ}$ ano, escola C, leciona há 8 anos).

Coexistem compreensões contraditórias sobre as possibilidades do trabalho do professor que podem indicar concepções de docência diferentes - um educador limitado a uma prática adaptacionista, mecânica, que busca produzir alunos dóceis, conformados com a realidade; ou um professor comprometido com um pensamento pedagógico assumidamente político, entendendo que o ato de educar implica numa tomada de decisão e intervenção no mundo, tomando os alunos como sujeitos histórico (FREIRE, 1987).

\footnotetext{
"Ser um bom professor é....eu acho que é incentivar o aluno a não parar mesmo que ele tenha dificuldade, mesmo que não seja a disciplina que ele goste, que ele tenha afinidade, eu acho que você estimular, para que pelo menos ele busque, que ele se identifique com alguma outra coisa, entendeu?! Não deixar ele com medo, né?! Com medo da disciplina, de aprender, de escrever principalmente, né? ” (Professora de Português Literatura e Redação, $9^{\circ}$ ano, escola C, leciona há menos de cinco anos).
}

A percepção de que os professores gostam da docência, estão disponíveis, é percebida por alguns alunos: Eles (os professores) sabem explicar bem a matéria e eles não explicam tipo sendo grossos. Eles explicam com brincadeira, explicam com vontade. Eles gostam do que eles fazem, entendeu? A gente percebe isso (Aluna, $9^{\circ}$ ano, escola $C$ ).

A partir das leituras e releituras das entrevistas, emerge o tema da arte como um ponto forte para a sensibilização dos alunos, nas escolas públicas e particulares, e um caminho com resultados positivos para o aprendizado, para a formação de 
comportamentos e valores. Também é mencionada a aprendizagem de conteúdos de outras disciplinas através das atividades de arte artísticas Uma das escolas particulares tinha em sua grade curricular várias linguagens - literatura, teatro, canto, artes plásticas, música. O relato de um professor enfatiza o diálogo interdisciplinar na escola.

(...) a escola tem essa perspectiva que eu acho muito bacana e eu percebo uma sensibilidade maior aqui na escola para essas questões artísticas. E isso se manifesta numa sensibilidade com o outro, nos assuntos que tocam. Então, eu acho que a perspectiva da arte que a escola tem também é importante para outras disciplinas. E aí é legal porque quando, em História, a gente vai passar um filme, os alunos já são superacostumados com a narrativa do filme, da música, da dança, das obras de arte. Então, facilita também o trabalho, porque são documentos históricos e registros históricos que a gente utiliza e os alunos são familiarizados com essas artes. Então, eles têm uma visão de mundo sobre as artes que é muito bacana, fora esse lado da sensibilidade. E isso a gente percebe bastante. Os alunos são mais sensiveis em relação ao outro e aos temas que tocam. E isso tem a ver um pouco com a relação com o corpo, com a dança. E eu acho isso legal. Tem teatro, a dança e a expressão corporal, porque isso é muito importante com essa molecada adolescente cheia das travas, dos medos, de encostar. E eu percebo que isso dá uma leveza na relação com o corpo e com o outro. E é isso, acho que trabalha essa sensibilidade da percepção das coisas e com outro. E na história é a relação do ser humano. Então, eu acho também que te torna mais sensível com as questões de mundo e eles trabalham essa sensibilidade (Professor de História, 9o ano, escola D, leciona há mais de dez anos).

Na escola C, a arte foi mencionada como um fator de incentivo para o estudo da Geometria, valorizado pela professora. Esse relato surgiu a partir de uma exposição de trabalhos sobre o corpo humano, a partir de imagens abstratas, que estava acontecendo na escola:

(...) a arte como um todo ajuda na formação do indivíduo. Através da arte, ele consegue perceber os valores, comportamentos, essas coisas todas. Assim, é importante ter a matéria no ciclo básico e desenvolver muito a percepção, a abstração. Através da arte, do desenho... ele percebe que a partir do plano ele pode ter uma profundidade. Se ele não tiver essa percepção, ele não consegue estudar tal matéria 
(Professora de Matemática, $7^{\circ}$ ano, escola B, leciona há mais de 25 anos).

A expressão aliada à imaginação pode ser experimentada pelo corpo, dança, artes, poesia. A imaginação instiga a criatividade e a inventividade, apoiando diferentes formas de expressão. São maneiras de estimular outras formas de relação com o conhecimento (VYGOTSKY, 2009). Os professores mencionam a experiência com a arte de forma muito positiva, uma possibilidade de bem-estar, de encontro consigo e com o outro. Acreditamos que a arte transforma a escola num espaço de reflexão, criação e fruição. O carinho e o vínculo com a escola foram pontos que chamaram a atenção nos relatos.

Na mesma direção que um dos relatos anteriores, a experiência com o corpo é destacada como uma aposta que busca romper com a lógica disciplinar, de pouca liberdade da escola, fazendo desse espaço uma oportunidade de contato com as emoções, de afirmação dos sujeitos.

Dança, eu acho bem interessante. Assim, o corpo.... Eles ficam diariamente sentados, estudando, uma dança eu acho que influenciaria, mudaria um pouco a postura deles, relaxaria também, uma forma de extravasar, é muito tenso a escola, ensino médio... muitos não dançam né?! Meninos principalmente... (Professora de Português Literatura e Redação - $9^{\circ}$ ano, escola C, leciona há menos de cinco anos).

Citada como um elo de ligação entre professor e aluno, a arte reforça a confiança e a troca motivadoras do aprendizado, neste relato:

(..) eu enfatizo pouco a parte teórica, ela vai, mas vai diluída, porque eu acho que eles precisam de uma experiência corporal e vivencial com arte que os ajude a entender, que potencialize: “Nossa eu posso! Eu consigo! (Professora de Artes, $7^{\circ}$ e $9^{\circ}$, escola A, leciona há mais de 20 anos).

Aparece também como uma possibilidade de crítica social, de posicionamento no mundo. As diferentes linguagens artísticas oferecem caminhos para explorar e expressar entendimentos do mundo que podem ser refletidos com crianças e adolescentes.

(...) a arte não causa apatia. Eles (os alunos) se interessam, eles gostam de ver. Às vezes eles acham estranho, horroroso, eles têm várias opiniões, mas não tem apatia. Quando você começa a mostrar imagens, obras de artes, eles começam a se desenvolver e dar a opinião deles. Então, pelo menos isso. Então, o fazer criativo também 
é incrível, a grande maioria gosta (Professora de Artes, $7^{\circ}$ e $9^{\circ}$ ano, escola A, leciona há 10 anos).

A partir do evento destacado, observa-se uma visão da arte articulada com o mundo, com a coletividade, com a história, como possibilidade de crítica, abandonando qualquer tentativa de uma arte preocupada exclusivamente com a satisfação. A arte tem colaborado com a produção de novos paradigmas para a compreensão de questões humanas.

Da mesma forma que os professores, os alunos compartilham da mesma leitura sobre o papel das artes na escola. Segundo os estudantes, era "cobrado" da mesma maneira que outras matérias, como Português, Matemática e História.

A gente tem aula de música, dança, artes visuais que é mais a plástica e... esqueci a outra, peraí... teatro, e elas tem 50 minutos por semana de cada então é um tempo inteiro por semana... eu acho importante, porque a arte é muito importante na vida e ajuda muito no aprendizado porque você ficar estudando matemática é muito cansativo. Não que seja uma aula fácil, muito pelo contrário, porque você é igualmente cobrado, mas o foco não é no resultado, é no processo e como se está desenvolvendo. Por exemplo, quando você chega na aula de matemática, fica muito difícil de acontecer isso porque você tem que achar o resultado e eu sei do processo para chegar a um resultado. Mas a importância das artes na escola é justamente isso. Além de você desenvolver a atividade criativa, é também focar em como a pessoa aprende, é uma ferramenta para você conhecer os alunos de uma forma muito boa, porque a arte vem de dentro, então você vai saber como aquela pessoa é e como ela está se expressando (Aluno do $9^{\circ}$ ano, escola, D).

Eu gosto muito de teatro até porque eu gosto muito da professora de teatro, eu também gosto muito de dança, eu acho que são importantes porque (...) é uma matéria como as outras. Então tinha que ser uma matéria que tivesse em todas as escolas, porque é uma outra atividade por que você está tendo duas horas de matemática e depois você vai ter teatro, aí você já se solta mais e você fica mais ligada. Na matemática é todo mundo lá com o caderno e a mesa e todo mundo anotando, e no teatro não, o teatro é mais comunicativo, te estimula a criatividade e você pode fazer outras coisas. (Aluna do $9^{\circ}$ ano, escola, D). 
O estímulo à prática artística dentro das aulas de artes plásticas também foi perceptível nas escolas públicas pesquisadas, mesmo com a identificação de limites para esse trabalho, como a ausência de certos materiais - a gente tem dificuldade de tudo. A gente precisa ter uma política pública que pense nisso. Não tem como trabalhar artes sem material, como isso é possível? Como faz esse milagre? (Professora de Inglês, $7^{\circ}$ e $9^{\circ}$ anos, escola, A, leciona há oito anos). É interessante ressaltar que, para a professora, é responsabilidade da gestão pública garantir materiais para a construção de um trabalho com artes de qualidade. Assim, existe uma dimensão da macropolítica que interfere no cotidiano, nas relações estabelecidas no interior da escola.

Outro aspecto que merece ser destacado é a importância das diferentes linguagens artísticas nas discussões de diversas disciplinas.

Eu sinto falta de colocar os meninos para desenhar em um ambiente criativo. Porque eles só desenham na aula de artes. Eu queria que tivesse um espaço para que eles pudessem desenhar. Por exemplo, quando estivéssemos trabalhando a Grécia antiga, eles pudessem desenhar os deuses, eles pudessem pensar na pólis desenhando. Mas, principalmente, eu queria que a gente tivesse condição de analisar obras de arte. Eu queria que a gente tivesse acesso a muitas imagens que a gente conseguisse. Com data show, a gente pode até fazer isso, não é? Olhar... por que estou na Idade Média? Por que esse quadro é mais escuro? Se eu chego no Renascimento, por que parece mais com a Grécia? Isso fica muito difícil de fazer. O data show não tem na sala, você tem que reservar, você tem que chegar mais cedo e eu acabo desistindo. E eu acho que filme, eu sou apaixonada por filme, eu acho que filme funciona, trechos de filmes funcionam muito bem. Eu gostaria de ter mais espaço de trabalhar com esses objetos. (Professora de História, $7^{\circ}$ e $9^{\circ}$ ano, escola C, leciona há mais de 10 anos).

A professora reconhece a importância das artes como expressão da cultura e da história humana para refletir sobre temas diversos, tomando a criatividade e a imaginação como elementos essenciais para a aprendizagem. Ela chama atenção para as dificuldades no planejamento de aulas que tragam uma interlocução com as artes pela ausência de equipamentos. Mesmo reconhecendo que a experiência do aprender acontece em uma realidade concreta, é preciso pensar quais são os caminhos possíveis para a ampliação das experiências dos alunos. 
Ainda que este não seja o foco desta pesquisa, verificou-se, no trabalho de campo, como o papel de destaque que as diferentes artes têm em um projeto pedagógico reflete positivamente nas relações entre professores e alunos; e nas relações entre os alunos e a escola e os professores e a escola. E, consequentemente, como isto influi nos processos de aprendizagem. Ao desenvolver aspectos como a criatividade, a expressividade, a sensibilidade, a subjetividade, através das aulas de música, artes cênicas, danças populares, cinema, artes plásticas, os alunos e professores de uma das escolas particulares participantes revelaram ter uma conexão profunda com a escola, que perpassa o simples anseio por estudar e ensinar. Neste caso, a escola se apresenta como uma parceira na formação de um ser humano crítico e autônomo, uma experiência para se levar afetivamente por toda a vida. 


\section{8}

\section{Considerações Finais}

Essa pesquisa teve como objetivo entender a afetividade nas relações de aprendizado no campo escolar. Entender como acontece a relação no processo de aprendizagem e qual a influência da relação professor-aluno. Nesse processo de investigação, foi considerada a perspectiva dos professores e alunos através de entrevistas, bem como do uso do questionário sobre o Clima Escolar, Adaptation and preliminary validation evidences of the School Climate Questionnaire Revised, Elementary and Middle School Version (SCS-MS) (PETRUCCI et. al., 2016). Estas estratégias permitiram uma aproximação dos sentidos dados para a relação professor-aluno e suas implicações no processo de aprendizagem. Estar imersa no contexto escolar foi um diferencial para a formação da pesquisadora, através dos desafios experimentados no campo, e também pela oportunidade de pensar o tema imerso numa realidade concreta, na interlocução direta com educadores e educandos. Esse contato ensinou a perceber a produção de sentidos através dos ditos e não-ditos, na observação das relações estabelecidas, na organização do espaço. Esse estudo não pretendeu criar generalizações a partir das realidades estudadas, mas identificar aspectos que podem colaborar com a reflexão do tema.

Em relação à escala aplicada aos alunos, foi possível identificar que o clima escolar tem interferência na qualidade das interações e nas experiências de aprendizagem A partir da aplicação, observa-se que aspectos emocionais interferem na prática pedagógicas e refletem na vida dos alunos. A motivação faz toda a diferença para as relações interpessoais no âmbito escolar e dos processos de ensino e aprendizagem.

Nas entrevistas com os professores, a questão “como se sentem” dando aula teve um paralelo com as respostas dos alunos sobre quais seriam seus professores preferidos. A responsabilidade do papel do professor nesta relação foi sinalizada nos relatos dos alunos, nos quais foi possível observar, por meio das palavras escolhidas, da entonação, das emoções, dos gestos e dos olhares, como eles são 
afetados pela relação com seus professores. Eles relataram se sentir afetados a cada palavra, frases ou até mesmo sob os olhares dos professores.

As entrevistas mostraram-se um espaço de interlocução repleto de sentidos, evidenciando as contradições e ambiguidades que atravessam a escola. As leituras e releituras das transcrições permitiram analisar a centralidade da afetividade para professores e alunos na construção de uma relação de qualidade, marcando as aprendizagens experimentadas na escola. O que não significa que tudo que é vivido na escola colabora para uma relação positiva. Foram identificados limites como a ausência de materiais e de estrutura para o trabalho pedagógico, principalmente nos contextos públicos. O olhar do professor mostrou-se potente, capaz de interferir na autoimagem dos estudantes. No caso de uma falta de abertura dos professores, na busca de explicações que encerram os alunos em rótulos ou estereótipos, pode-se produzir uma história de não pertencimento à escola.

Notou-se que os professores que lecionam nas escolas particulares e também nas públicas demonstraram uma motivação maior para ensinar quando conseguem estabelecer um equilíbrio de suas expectativas de crescimento e qualificação profissional com a prática de trabalho na escola. Nas entrevistas foram citados projetos que foram colocados em prática na escola particular e na pública e falas como " se o meu aluno da escola particular tem tal livro eu também quero que o da escola pública tenha também, eu lutei por isso”.

A partir das entrevistas, identifica-se a importância da arte na escola, na sensibilização dos alunos e em dar sentido para o aprendizado. Os alunos que relataram um contato regular com a arte demonstraram mais espontaneidade nas entrevistas. Esse tema revelou a amplitude que envolve e abriu novos caminhos de estudo e novos questionamentos a serem feitos que não couberam na sua devida proporção nesse estudo.

Acredita-se que apesar da relevância desse estudo, foram perceptíveis algumas limitações. O estudo foi realizado na Zona Sul da cidade do Rio de Janeiro no bairro de Botafogo. Com isso, prevaleceu uma homogeneidade dos participantes, em termos de localidade. Aplicou-se apenas um questionário para medir o clima escolar. Mesmo com as limitações apontadas, considera-se que a pesquisa realizada permitiu o conhecimento maior sobre as relações na escola. Com isso, pôde-se compreender a importância da ampliação do estudo com uma 
diversidade maior de participantes, escolas e locais. Sendo assim, esse tema mostrou ser um campo fértil para pesquisas científicas e que permite desdobramentos importantes de investigação sobre a relação da afetividade com o aprendizado. Pode-se pensar, por exemplo, em possíveis relações entre a prática artística e a criatividade facilitadoras do aprendizado, trazendo a expressão e o questionamento como fatores que devem ser considerados essenciais no ambiente escolar. Além do exposto, esta dissertação mostrou como a educação se dá por lutas, um ato político, e que não existe sem conflitos, sendo necessário quebrar com as idealizações. 
9

\section{Referências bibliográficas}

ALMEIDA, L.R. Wallon e a Educação. In: ALMEIDA, L. (org.) e MAHONEY, A.A. (org.). Henri Wallon - Psicologia e Educação. São Paulo, SP: Edições Loyola, $10^{\text {a }}$ ed. 2011.

ARROYO M.G. A Infância Interroga a Pedagogia. In: Educação e Práticas Sociais. Petrópolis RJ, Vozes, 2008.

2001.

Ofício de mestre: imagens e auto-imagens. Petrópolis: Vozes,

ARIÈS, P. História social da criança e da família. 2. ed Rio de Janeiro: LTC, 1981.

BARBOSA, A.M. Arte-Educação no Brasil, Realidade hoje e expectativas futuras. Estud. av. v. 3, n. 7 São Paulo set./dez. 1989

CASTRO, L.R. O futuro da infância e outros escritos / Lucia Rabello de Castro. - 1. ed. - Rio de Janeiro: 7Letras, 2013.

. Uma teoria da infância da contemporaneidade. In: CASTRO, Lucia Rabello de (org.) Infância e adolescência na cultura do consumo. Rio de Janeiro: Nau, 1998, 1999.

COLLARES, C.L. \& MOYSÉS, M.A. A (A Patologização da Educação). Série Ideias (23), São Paulo, FDE, 25-31, 1994.

DANTAS H. A Afetividade e a Construção do Sujeito na Psicogenética de Wallon In: Y. La Taille, H. H. Dantas \& M. K. Oliveira (Orgs.) Vygotsky e Wallon: teorias psicogenéticas em discussão. São Paulo: Summus Editorial Ltda, 1992.

DAYRELL, J. A escola como espaço sociocultural. In: DAYRELL, J. (Org.). Múltiplos olhares sobre educação e cultura. Belo Horizonte: UFMG, 1996.

DAYRELL, J. A escola “faz” as juventudes? Reflexões sobre a socialização da juventude. Educação e Sociedade, Campinas, v. 28, n. 100, 2007. p. 1.105- 1.129.

EISNER, Elliot W. O que pode a educação aprender das artes sobre a prática da educação? Currículo sem Fronteiras, v. 8, n. 2, pó. 2-17, Jul/Dez 2008. Disponível em: www.curriculosemfronteiras.org/vol8iss2articles/eisner.pdf.

ESPIRITO SANTO, A.A. do, et. al., Esporte, Formação e Sistema Conselhos: é possível o diálogo? In: FORMAÇÃO: ética, política e subjetividades na Psicologia/ organizadores: Carlos Eduardo Nórte, Raiana Micas Macieira, Ana Lucia de Lemos Furtado. Rio de Janeiro: Conselho Regional de Psicologia, 2010.

FREITAS M.T. de A. Vygotsky Um Século Depois... Juiz de Fora: EDUFJE, 1998. 
FREIRE, P. Pedagogia do Oprimido, $17^{\mathrm{a}}$ ed., Rio de Janeiro, Paz e Terra, 1987.

Pedagogia da Autonomia: Saberes Necessários à Prática

Educativa São Paulo: Paz e Terra, 1996 (Coleção leitura).

Professora sim, tia não cartas a quem ousa ensinar, São PauloSP, Editora Olho d’Água, 1997.

FRIGOTTO G. Escola 'sem' partido: esfinge que ameaça a educação e a sociedade brasileira. Gaudêncio Frigotto (org.). Rio de Janeiro: LPP/Uerj, 2017.

GALVÃO, I. Henri Wallon: uma concepção dialética do desenvolvimento infantil. $4^{\mathrm{a}}$.ed. Petrópolis, RJ: Vozes, 1995. (Educação e conhecimento)

GUZZO R.S.L. et. al. Psicologia e Educação no Brasil: uma visão da história e possibilidades nessa relação. In Psic. Teor. e Pesq. vol.26 no. Spe Brasília 2010.

ISAIA S.M. de Aguiar Contribuições da Teoria Vygostiana Para Uma Fundamentação Psico-Epistemológica da Educação. In. FREITAS M. T. de A Vygotsky um Século Depois... Juiz de Fora: EDUFJE,1998.

KRAMER, S. Infância, cultura contemporânea e educação contra a barbárie IN: Kramer, Sonia; Bazílio, Luiz Cavalieri. Infância, educação e direitos humanos. São Paulo: Cortez, 2011.

LIGHTFOOT, C.; VALSINER, J. Parental belief systems under the influence: Social guidance of the construction of personal cultures. In: Sigel, I.; MCGILLICUDDY-DELISI, A.; GOODNOW, J. (Ed.). Parental belief systems: the psychological consequences for children. Hillsdale: Lawrence Erlbaum Associates, 1992. p. 393-414.

MAHONEY, A.A.; ALMEIDA, L.R. de (org.) Henry Wallon: Psicologia e Educação. São Paulo. Edições Loyola, 2010.

MAHONEY, A.A. A Constituição da pessoa: desenvolvimento e aprendizagem. In: MAHONEY, A.A.; ALMEIDA, C.R. de. (Orgs). A constituição da pessoa na proposta de Henri Wallon. São Paulo: Loyola, 2004.

MEIRA, M.E.M. Para uma Crítica da Medicalização na Educação. Psicol. Esc. Educ. v.16, no. 1, Maringá Jan./June 2012.

MELO, L.C.M. de; SOUZA, G.S.; DAYRELL, J. Escola e juventude: Uma relação possível? Paidéia r. do cur. de ped. da Fac. de Ci. Hum. Soc. e da Saú., Univ. Fumec Belo Horizonte Ano 9 n.12 p. 161-186 jan. /jun. 2012.

OLIVEIRA, M.K. O problema da afetividade em Vygotsky. In Y. La Taille, H. H. Dantas \& M.K. Oliveira (Orgs.), Piaget, Vygotsky e Wallon: teorias psicogenéticas em discussão. São Paulo: Summus Editorial Ltda., 1992, p. 75-84.

. Vygotsky e o Processo da Formação de Conceitos In Y. La Taille, H. Dantas \& M.K. Oliveira (Orgs.), Piaget, Vygotsky e Wallon: teorias psicogenéticas em discussão. São Paulo: Summus Editorial Ltda., 1992, p. 23-34.

Vygotsky - aprendizado e desenvolvimento: um processo sóciohistórico. São Paulo: Editora Scipione, 1997. 
PATTO, M.H. Para uma Crítica da Razão Psicométrica. Psicol. USP [online]. v. 8, n. 1, p. 47-62, 1997.

PENNA F.A. O Escola sem Partido como chave de leitura do fenômeno educacional in: Escola 'sem' partido: esfinge que ameaça a educação e a sociedade brasileira. Gaudêncio Frigotto (org.). Rio de Janeiro: LPP/Uerj, 2017.

PETRUCCI, GW.; BORSA, J.C.; DAMÁSIO, B.F.; KOLLER, S.H. Adaptation and preliminary validation evidences of the School Climate Questionnaire Revised, Elementary and Middle School Version (SCS-MS), Psicologia: Reflexão e Crítica Psychology: Research and Review, 2016.

PRESTES, Z. Quando não é quase a mesma coisa: análise das traduções de Lev Seminovicht Vigostki no Brasil repercussões no campo educacional. Tese de Doutorado, Faculdade de Educação, Programa de Pós-Graduação em Educação, Universidade de Brasília, Brasília, DF, 2010.

REGO, T.C. Vygotsky, Uma perspectiva histórico-cultural da educação Petrópolis, RJ, Vozes, 1995.

SOUZA, J.S. A Psicologia do Desenvolvimento e as Contribuições de Lev Vygotsky. In. FREITAS M. T. de A Vygotsky Um Século Depois... Juiz de Fora: EDUFJE,1998.

Subjetividade Em Questão: A Infância como crítica da cultura Rio de Janeiro: 7Letras, 2005 (2ª edição).

Re significando a psicologia do desenvolvimento: Uma contribuição crítica à pesquisa da infância In. Infância: Fios e desafios da pesquisa / Kramer S. e LEITE I. M. (orgs), Campinas- SP: Papirus, 1996 (Práticas pedagógicas).

SOUZA, M.P. de C. e Políticas e práticas de avaliação na creche: uma pesquisa na rede pública do Município do Rio de Janeiro - Pontifícia Universidade Católica do Rio de Janeiro, Departamento de Educação. Tese de Doutorado, 2017.

SPINK, M.J. Práticas discursivas e produção de sentidos no cotidiano: aproximações teóricas e metodológicas. São Paulo: Cortez, 1999.

TACCA, M.C.V.R. e GONZALEZ Rey, F.L. Produção de sentido subjetivo: as singularidades dos alunos no processo de aprender. In: Psicol. cienc. prof. v. 28, n. 1 Brasília mar. 2008.

VYGOSTKI, L.S. A Formação Social da Mente, 4. Ed. São Paulo, Martins Fontes, 1984, 1991, 2007.

A Construção do Pensamento e da Linguagem. Tradução: São Paulo. Ed. Martins Fontes, 2001.

Pensamento e Linguagem, 2a ed. São Paulo, Martins Fontes, 1989.

Imaginação e criação na infância: ensaio psicológico: livro para professores. Apresentação e comentários de Ana Luiza Smolka; tradução de Zoia Prestes. São Paulo: Ática, 2009. 
2013.

El arte y la vida In: Psicologia Del Arte, Ediciones Paidós Canadá, WALLON, H. A evolução psicológica da criança. São Paulo: Martins Fontes, 1968.

As Origens do Caráter da Criança. Difusão Européia do livro, SP, 1971. 
10. ANEXOS

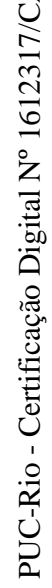




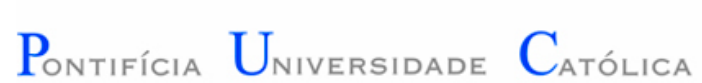

DO RIO DE JANEIRO

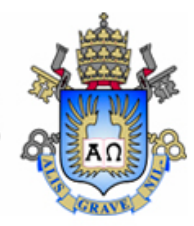

\section{PONTIFÍCIA UNIVERSIDADE CATÓLICA DO RIO DE JANEIRO- PUC-RJ}

\section{TERMO DE ASSENTIMENTO}

\section{Prezado aluno (a):}

Viemos convidá-lo (a) a participar de uma pesquisa que tem como título “A relevância da afetividade nos processos de aprendizagem”.

O objetivo da pesquisa é analisar a afetividade na relação professor aluno e como a arte influencia essa relação.

Os alunos que irão participar dessa pesquisa são do $7^{\circ}$ ano e $9^{\circ}$ ano (fundamental II) e os respectivos professores. A pesquisa será feita no seu colégio, onde os alunos responderão a 8 perguntas para a pesquisadora e mais um questionário para marcar respostas: “não, às vezes, muitas vezes”, esse questionário será impresso e entregue para cada aluno responder individualmente.

As entrevistas serão gravadas através de um gravador portátil.

Para que você possa decidir se participará deste estudo, precisa conhecer seus benefícios, riscos e implicações.

\section{RISCOS}

A participação nesse projeto, em princípio, não traz qualquer tipo de risco ou desconforto ao participante, a não ser algum possível sentimento de timidez que algumas pessoas podem ter diante de questionários. De todo modo, fica claro que você poderá desistir da pesquisa a qualquer momento, e caso manifeste algum desconforto a atividade poderá ser interrompida, sem qualquer prejuízo para você.

\section{BENEFÍCIOS}

Você não será remunerado por participar dessa pesquisa ou obterá benefícios diretos, porém, com a realização dela, espera-se ter um conhecimento maior a respeito do que pensam e esperam da afetividade na relação professoraluno no processo de aprendizado. Isso poderá permitir, entre outras iniciativas, a formulação de programas de orientação e intervenção com os professores que favoreçam o desenvolvimento da relação e motivação dos alunos e professores na escola.

\section{CARÁTER CONFIDENCIAL DOS REGISTROS}

A pesquisadora irá tratar a sua identidade com padrões profissionais de sigilo. O nome ou o material que identifique você, especificamente, e a sua participação não será liberado sem a sua permissão. As informações prestadas serão usadas apenas para fins de estudo e pesquisa. Você será identificado (a) por um código e não por nome. 


\section{CUSTOS}

Não haverá qualquer custo ou forma de pagamento pelo seu consentimento, nem pela sua participação no estudo.

\section{BASES DA PARTICIPAÇÃO}

Seu consentimento e participação neste estudo é completamente voluntária e só será confirmada a partir do consentimento dado pelo responsável para que você participe dessa pesquisa. Você pode recusar-se a assinar esse termo, bem como poderá interromper sua participação a qualquer momento durante a atividade sem penalidades.

\section{GARANTIA DE ESCLARECIMENTOS}

Nós convidamos você ou seus familiares a fazerem perguntas a qualquer momento do estudo. Neste caso, por favor, entre em contato com Patricia Siqueira Oliveira no telefone (21) 98452-3352 ou por e-mail: patriciaoliveira.psi@hotmail.com. Sendo a orientadora da pesquisa, Luciana F. Pessôa e mail: pessoalf@gmail.com. Se tiver perguntas com relação a seus direitos como participante do estudo, também pode contar com contatos imparciais com a Comissão de Ética em Pesquisa da PUC-RJ, Pontifícia Universidade Católica do Rio de Janeiro, Rua Marquês de São Vicente, 225, Gávea - Rio de Janeiro, RJ Brasil - 22451-900 Cx. Postal: 38097 - Telefone: (55 21) 3527-1001. Esse documento é de duas vias, depois de assinada uma via ficará com a pesquisadora e a outra com o voluntário participante da pesquisa.

Eu recebi uma cópia assinada deste formulário de consentimento.

(Assinatura do participante)

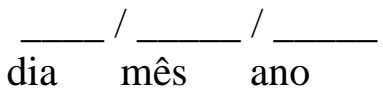

(Nome do participante - letra de forma)

Eu, abaixo assinado, expliquei completamente os detalhes relevantes deste estudo ao participante indicado acima.

(Assinatura da pessoa que obteve o consentimento)

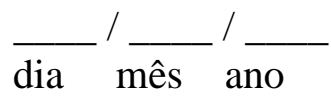




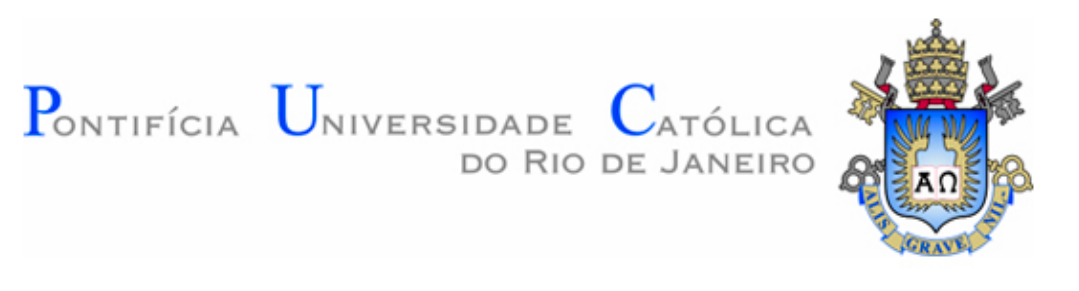

\section{PONTIFÍCIA UNIVERSIDADE CATÓLICA DO RIO DE JANEIRO- PUC-RJ}

\section{TERMO DE CONSENTIMENTO LIVRE E ESCLARECIDO}

Prezada senhor (a):

Viemos convidá-lo (a) a participar de uma pesquisa que tem como título “A relevância da afetividade nos processos de aprendizagem”. A pesquisa tem por finalidade analisar o papel da afetividade no processo de aprendizagem, a partir da relação professor-aluno e a arte como facilitadora nesse processo.

De acordo com a literatura da área do contexto escolar e segundo estudos recentes é bastante esclarecedor para a melhor compreensão da relação professor e aluno no processo de aprendizado conhecer como que os alunos e professores lidam com essa relação na escola. Acreditamos na importância dessa pesquisa pois nos dará informações valiosas sobre como o aluno dentro do seu contexto escolar se desenvolve no processo de aprendizado e qual a influência da arte para esse processo. Os resultados obtidos poderão ser usados na orientação de professores e da escola em seu esforço para ajudar os alunos a se desenvolverem no seu processo escolar.

Para que você possa decidir se participará deste estudo, precisa conhecer seus benefícios, riscos e implicações.

\section{OBJETIVO DO ESTUDO}

Esse estudo se propõe a investigar o afeto na relação professor-aluno e como a arte influencia nessa relação.

\section{PROCEDIMENTOS DO ESTUDO}

Se você concordar em participar deste estudo, além de assinar este termo de consentimento, preencherá um formulário de identificação e um com perguntas a respeito de sua condição sociodemográfica, isto é, idade, escolaridade, estado civil, profissão, etc. Em seguida, serão aplicados um questionário e oito perguntas para os alunos e oito perguntas para os professores. As entrevistas serão gravadas através de um gravador portátil. Para essa sua participação ocorrer será marcado com você um dia, horário e local de sua conveniência.

\section{RISCOS}

A participação nesse projeto, em princípio, não traz qualquer tipo de risco ou desconforto ao participante, a não ser algum possível sentimento de timidez que algumas pessoas podem ter diante de questionários. De todo modo, fica claro que você poderá desistir da pesquisa a qualquer momento, e caso manifeste algum desconforto a atividade poderá ser interrompida, sem qualquer prejuízo para você. 


\section{BENEFÍCIOS}

Você não será remunerado por participar dessa pesquisa ou obterá benefícios diretos, porém, com a realização dela, espera-se ampliar o conhecimento a respeito do que pensam e esperam da afetividade na relação professor-aluno no processo de aprendizado. Acredita-se que tal conhecimento permitirá inferências sobre trajetórias de desenvolvimento escolar dos alunos e como a arte pode influenciar nesse contexto. Isso poderá permitir, entre outras iniciativas, a formulação de programas de orientação e intervenção com os professores que favoreçam o desenvolvimento da capacidade relacional e motivacional dos alunos e professores.

\section{CARÁTER CONFIDENCIAL DOS REGISTROS}

A pesquisadora irá tratar a sua identidade com padrões profissionais de sigilo. O nome ou o material que identifique você, especificamente, e a sua participação não será liberado sem a sua permissão. As informações prestadas serão usadas apenas para fins de estudo e pesquisa, e todas, à exceção das prestadas no Formulário de Identificação, serão identificadas por um código e não por nome.

\section{CUSTOS}

Não haverá qualquer custo ou forma de pagamento pelo seu consentimento, nem pela sua participação no estudo.

\section{BASES DA PARTICIPAÇÃO}

Seu consentimento e participação neste estudo é completamente voluntária e você pode recusar-se a assinar esse termo, bem como poderá interromper sua participação a qualquer momento durante a atividade sem penalidades.

\section{GARANTIA DE ESCLARECIMENTOS}

Nós convidamos você ou seus familiares a fazerem perguntas a qualquer momento do estudo. Neste caso, por favor, entre em contato com Patricia Siqueira Oliveira no telefone (21) 98452-3352 ou por e-mail: patriciaoliveira.psi@hotmail.com. Sendo a orientadora da pesquisa, Luciana F. Pessôa e mail: pessoalf@gmail.com. Se tiver perguntas com relação a seus direitos como participante do estudo, também pode contar com contatos imparciais com a Comissão de Ética em Pesquisa da PUC-RJ, Pontifícia Universidade Católica do Rio de Janeiro, Rua Marquês de São Vicente, 225, Gávea - Rio de Janeiro, RJ Brasil - 22451-900 Cx. Postal: 38097 - Telefone: (55 21) 3527-1001. Esse documento é de duas vias, depois de assinada uma via ficará com a pesquisadora e a outra com o voluntário participante da pesquisa.

$\mathrm{Li}$ as informações acima e entendi o propósito deste estudo assim como os benefícios e riscos potenciais da participação no mesmo. Tive a oportunidade de fazer perguntas e todas foram respondidas. Eu, por intermédio deste, dou livremente meu consentimento para participar neste estudo. Entendo que não receberei compensação monetária por minha participação neste estudo. 


\section{Pontifícia Universidade C $_{\text {atólica }}$

Termo referente a pesquisa: A relevância da afetividade nos processos de aprendizagem

Eu recebi uma cópia assinada deste formulário de consentimento.

(Assinatura do participante)

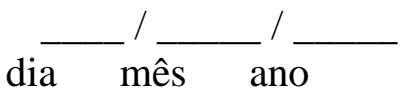

(Nome do participante - letra de forma)

Eu, abaixo assinado, expliquei completamente os detalhes relevantes deste estudo ao participante indicado acima.

(Assinatura da pessoa que obteve o consentimento)

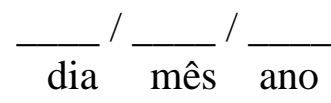




\section{Questionário de Clima Escolar - Versão Revisada Ensino Fundamental} (QCE-EF)

Qual é o seu nome completo?

Quantos anos você tem? qual é a sua série?

Nós queremos saber como você se sente em relação a sua escola. Por favor, nos diga se você concorda ou não concorda com cada uma das frases abaixo. Marque apenas um número depois de cada frase. Por favor, leia com atenção cada frase antes de responder.

\begin{tabular}{|c|c|c|}
\hline Não concordo & Não tenho certeza & Concordo \\
\hline 1 & $\mathbf{2}$ & $\mathbf{3}$ \\
\hline
\end{tabular}

\begin{tabular}{|c|c|c|c|}
\hline & $\begin{array}{c}\text { Não } \\
\text { concordo }\end{array}$ & $\begin{array}{l}\text { Não tenho } \\
\text { certeza }\end{array}$ & Concordo \\
\hline $\begin{array}{l}\text { 1. Algumas crianças na minha escola } \\
\text { muitas vezes dizem que vão bater ou } \\
\text { machucar os outros }\end{array}$ & 1 & 2 & 3 \\
\hline $\begin{array}{l}\text { 2. As crianças na minha escola se } \\
\text { comportam bem }\end{array}$ & 1 & 2 & 3 \\
\hline $\begin{array}{l}\text { 3. Na minha escola, todas as } \\
\text { crianças são tratadas da mesma } \\
\text { forma, não importa se seus pais } \\
\text { são ricos ou pobres }\end{array}$ & 1 & 2 & 3 \\
\hline $\begin{array}{l}\text { 4. Os pais muitas vezes ajudam na } \\
\text { minha escola }\end{array}$ & 1 & 2 & 3 \\
\hline $\begin{array}{l}\text { 5. As crianças na minha escola são } \\
\text { cuidadosas com as outras pessoas }\end{array}$ & 1 & 2 & 3 \\
\hline $\begin{array}{l}\text { 6. As crianças na minha escola } \\
\text { muitas vezes se machucam quando } \\
\text { estão na escola }\end{array}$ & 1 & 2 & 3 \\
\hline $\begin{array}{l}\text { 7. Todo mundo é tratado } \\
\text { igualmente bem na minha escola }\end{array}$ & 1 & 2 & 3 \\
\hline $\begin{array}{l}\text { 8. Meus pais geralmente } \\
\text { participam das reuniões de pais na } \\
\text { minha escola }\end{array}$ & 1 & 2 & 3 \\
\hline $\begin{array}{l}\text { 9. Minha escola geralmente é } \\
\text { muito barulhenta }\end{array}$ & 1 & 2 & 3 \\
\hline $\begin{array}{l}\text { 10. Meus professores trabalham } \\
\text { bastante para que eu tenha bons } \\
\text { resultados nas tarefas e nas provas }\end{array}$ & 1 & 2 & 3 \\
\hline $\begin{array}{l}\text { 11. Os professores da minha escola } \\
\text { ajudam os alunos com os seus } \\
\text { problemas }\end{array}$ & 1 & 2 & 3 \\
\hline
\end{tabular}




\begin{tabular}{|c|c|c|c|}
\hline $\begin{array}{l}\text { 12. Quando temos brincadeiras ou jogos } \\
\text { divertidos na minha escola, são sempre as } \\
\text { mesmas crianças que comandam }\end{array}$ & 1 & 2 & 3 \\
\hline $\begin{array}{l}\text { 13. Na minha escola, crianças de todas as } \\
\text { cores de pele são tratadas da mesma } \\
\text { forma }\end{array}$ & 1 & 2 & 3 \\
\hline $\begin{array}{l}\text { 14. Na minha escola, é sempre o } \\
\text { mesmo aluno que ajuda o } \\
\text { professor }\end{array}$ & 1 & 2 & 3 \\
\hline $\begin{array}{l}\text { 15. As crianças na minha escola } \\
\text { gostam umas das outras }\end{array}$ & 1 & 2 & 3 \\
\hline $\begin{array}{l}\text { 16. As crianças na minha escola } \\
\text { confiam umas nas outras }\end{array}$ & 1 & 2 & 3 \\
\hline $\begin{array}{l}\text { 17. Eu sinto que eu posso me sair } \\
\text { bem nesta escola }\end{array}$ & 1 & 2 & 3 \\
\hline $\begin{array}{l}\text { 18. Minha escola geralmente está limpa e } \\
\text { organizada }\end{array}$ & 1 & 2 & 3 \\
\hline $\begin{array}{l}\text { 19. Meus professores se preocupam } \\
\text { comigo }\end{array}$ & 1 & 2 & 3 \\
\hline $\begin{array}{l}\text { 20. Algumas crianças trazem armas ou } \\
\text { facas para a minha escola }\end{array}$ & 1 & 2 & 3 \\
\hline $\begin{array}{l}\text { 21. Quando brincamos, são sempre as } \\
\text { mesmas crianças que utilizam as coisas, } \\
\text { como um computador, uma bola ou } \\
\text { outros brinquedos }\end{array}$ & 1 & 2 & 3 \\
\hline $\begin{array}{l}\text { 22. Na minha escola, as crianças ajudam } \\
\text { umas às outras }\end{array}$ & 1 & 2 & 3 \\
\hline $\begin{array}{l}\text { 23. Na minha escola, são sempre as } \\
\text { mesmas crianças que são escolhidas para } \\
\text { participar de atividades extras ou } \\
\text { especiais }\end{array}$ & 1 & 2 & 3 \\
\hline $\begin{array}{l}\text { 24. As crianças na minha escola brigam } \\
\text { muito }\end{array}$ & 1 & 2 & 3 \\
\hline $\begin{array}{l}\text { 25. As crianças na minha escola } \\
\text { respeitam os professores }\end{array}$ & 1 & 2 & 3 \\
\hline 26. Eu gosto de aprender nesta escola & 1 & 2 & 3 \\
\hline $\begin{array}{l}\text { 27. Meus pais visitam a minha escola } \\
\text { com frequência }\end{array}$ & 1 & 2 & 3 \\
\hline $\begin{array}{l}\text { 28. Meus professores acreditam que eu } \\
\text { posso ter bons resultados nos trabalhos } \\
\text { da escola }\end{array}$ & 1 & 2 & 3 \\
\hline $\begin{array}{l}\text { 29. Os pais geralmente vêm até a minha } \\
\text { escola para ajudar em atividades } \\
\text { especiais }\end{array}$ & 1 & 2 & 3 \\
\hline $\begin{array}{l}\text { 30. Os professores na minha escola nos } \\
\text { ajudam com nossos problemas escolares }\end{array}$ & 1 & 2 & 3 \\
\hline 31. Na minha escola, meninos e meninas & 1 & 2 & 3 \\
\hline
\end{tabular}




\begin{tabular}{|c|c|c|c|}
\hline são tratados igualmente bem & & & \\
\hline $\begin{array}{l}\text { 32. Na minha escola, os professores são } \\
\text { justos com todo mundo }\end{array}$ & 1 & 2 & 3 \\
\hline $\begin{array}{l}\text { 33. As crianças na minha escola falam } \\
\text { palavrões umas para as outras }\end{array}$ & 1 & 2 & 3 \\
\hline $\begin{array}{l}\text { 34. As crianças na minha escola } \\
\text { respeitam umas às outras }\end{array}$ & 1 & 2 & 3 \\
\hline $\begin{array}{l}\text { 35. Eu posso conversar com meus } \\
\text { professores sobre os meus problemas }\end{array}$ & 1 & 2 & 3 \\
\hline $\begin{array}{l}\text { 36. Meus pais geralmente vêm até a } \\
\text { minha escola para se encontrar com os } \\
\text { meus professores }\end{array}$ & 1 & 2 & 3 \\
\hline $\begin{array}{l}\text { 37. Meu professor faz eu me sentir bem } \\
\text { comigo mesmo (a) }\end{array}$ & 1 & 2 & 3 \\
\hline
\end{tabular}

Obrigada! Confira se você respondeu todas as perguntas. 